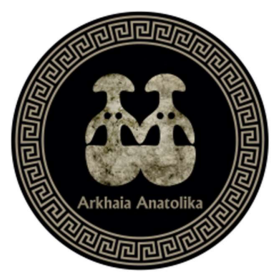

Arkhaia Anatolika

Anadolu Arkeolojisi Araştırmaları Dergisi

The Journal of Anatolian Archaeological Studies

Volume 4 (2021)

\title{
Aziz Nikolaos Kilisesi, Kuzey Ek Yapısı Tuğla Süslemeleri: Rozet Motifi ya da Yenilmez Güneş "Sol Invictus"
}

\author{
St. Nicholas Church, Brick Decorations of Northern Annex: Rosette \\ Motif or Invincible Sun "Sol Invictus"
}

\section{Ebru Fatma FINDIK}

(iD https://orcid.org/0000-0001-9150-0884

Geliş Tarihi: 05.01.2021 | Kabul Tarihi: 25.01.2021 | Online Yayın Tarihi: 18.02.2021

Makale Künyesi: Fındık, E. F. (2021). Aziz Nikolaos Kilisesi, Kuzey Ek Yapısı Tuğla Süslemeleri: Rozet Motifi ya da Yenilmez Güneş "Sol Invictus". Arkhaia Anatolika, 4, 41-82. DOI: 10.32949/Arkhaia.2021.26
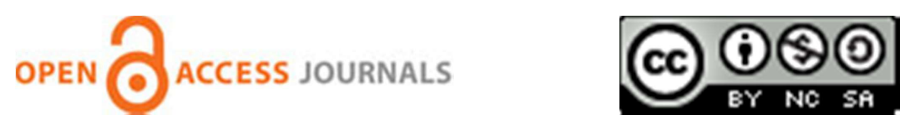

Arkhaia Anatolika, Anadolu Arkeolojisi Araştırmaları Dergisi "Açık Erişimli" (Open Access) bir dergidir. Kullanıcılar, dergide yayınlanan makalelerin tamamın tam metin olarak okuyabilir, indirebilir, makalelerin çıktısını alabilir ve kaynak göstermek suretiyle bilimsel çalışmalarında bu makalelerden faydalanabilir. Bunun için yayıncıdan ve yazar(lar)dan izin almasına gerek yoktur.

Dergide yayınlanan makalelerin bilimsel ve hukuki sorumluluğu tamamen yazar(lar)ına aittir.

Arkhaia Anatolika, The Journal of Anatolian Archaeological Studies follows Open Access as a publishing model. This model provides immediate, worldwide, barrier-free access to the full text of research articles without requiring a subscription to the articles published in this journal. Published material is freely available to all interested online readers.

The scientific and legal propriety of the articles published in the journal belongs exclusively to the author(s). 


\title{
Aziz Nikolaos Kilisesi, Kuzey Ek Yapısı Tuğla Süslemeleri: Rozet Motifi ya da Yenilmez Güneş "Sol Invictus”
}

\author{
St. Nicholas Church, Brick Decorations of Northern Annex: Rosette Motif or \\ Invincible Sun "Sol Invictus"
}

\section{Ebru Fatma FINDIK*}

\author{
Prof. Dr. S. Y. Ötüken'in Anısina
}

\section{Öz}

$\mathrm{Bu}$ makalede Aziz Nikolaos Kilisesi kuzey ve kuzeydoğu ek yapıların cephesinde bulunan tuğla rozetlerin kökeni, kronolojisi ve sembolik anlamı tartışılmıştır. Aziz Nikolaos Kilisesi ek yapıları, 1989-2009 yılları arasında, Prof. Dr. S. Y. Ötüken tarafından yürütülen kazılarda tümüyle açığa çıkarılmıştır. 2000 yılında "DemreMyra Aziz Nikolaos Kilisesi Kuzey Ek Yapısının Yeni Bir Değerlendirmesi" başlıklı makalede kuzey ek yapısının mimarisi, mimari plastik taş eserleri, seramik ve sikke buluntuları değerlendirilmiştir. Yayında kuzey ek yapısının K5 mekânı cephesindeki tuğla rozetten bahsedilmiş ancak motif detaylı bir çalışmaya konu olmamıştır. Tuğla rozetler özellikle Orta ve Geç Bizans Dönemi'nde başkent Konstantinopolis (İstanbul), Anadolu, Balkanlar, Yunanistan ve Ege adalarındaki yapıların cephesinde karşımıza çıkar. Bu tip tuğla rozetler saray, kilise, episkopeion, kule, kale ve çeşme gibi çok farklı işleve sahip yapılarda uygulanmıştır. Benzer motifin Beylikler ve Erken Osmanlı Dönemi yapılarında yaygın oluşu, motifin sürekliliğine işaret ettiği gibi Bizanslı ustalarca yapıldığına dair bir tartışma yaratır. Araştırmacılar tarafından benzer tuğla süslemeler 'rozet, güneş motifi, 1şık sembolü, güneş kursu, disk, güneş diski ve yuvarlak motifler' gibi farklı şekillerde adlandırılmıştır. Yayınlarda motifin terminolojisi, sembolik anlamı, köken ve kronolojisi konusunda ortak bir görüş olmadığı dikkati çeker.

Bu çalışmada Aziz Nikolaos Kilisesi kuzey ve kuzeydoğu ek yapılarının cephesindeki tuğla rozetler farklı coğrafyalardan örneklerle detaylı bir şekilde karşılaştırılmıştır. Kilisenin kuzeydoğu ek yapısı, cephesindeki tuğla rozet boyalı ve orijinal motifin belirlenebildiği ünik bir örnek olması açısından önemlidir. Bu bağlamda kuzey ve kuzeydoğu ek yapıdaki rozetler ilginç sonuçlar ortaya koyar. Amacımız motifin kökeni ve kronolojisini belirleyerek, pagan inanış kaynaklı olduğu düşünülen motifin sembolik anlamının Erken Hristiyanlık Dönemi'nde nasıl dönüştürüldüğünü örneklerle ortaya koymaktır. Bu bağlamda 3. yüzyıldan itibaren Roma'da yaygınlaşan Yenilmez Güneş/Sol Invictus inancının Hristiyanlık üzerindeki etkileri araştırmacıların görüşleri çerçevesinde tartışılmıştır. Sonuçların gelecekte bu konuda yapılacak benzer çalışmalara önemli bir referans oluşturmasını umuyoruz.

Anahtar Kelimeler: Myra, Bizans, Aziz Nikolaos Kilisesi, tuğla rozet, güneş motifi, Sol Invictus

\footnotetext{
* Dr. Öğr. Üyesi Ebru Fatma Fındık, Hatay Mustafa Kemal Üniversitesi, Fen-Edebiyat Fakültesi, Sanat Tarihi Bölümü, Hatay/TR. E-mail: effindik@mku.edu.tr. / Orcid iD: 0000-0001 9150-0884

Bu makale 1989-2009 yılları Aziz Nikolaos Kilisesi kazı başkanı ve değerli hocam Prof. Dr. S. Yıldız Ötüken'in 10 Eylül 2020 yılında vefatının ardından anısına ithafen yazılmıştır.
} 


\begin{abstract}
In this article, brick rosettes on the façade of northern and north-eastern annex of St Nicholas Church are discussed in terms of origin, chronology and symbolic meaning. Northern and north-eastern annex of St Nicholas Church were revealed completely during the excavations led by Prof. Dr. S. Y. Ötüken between 1989-2009. In the article "A New Review on Northern Additional Structure of Demre-Myra St Nicholas Church", architecture of the northern annex, architectural plastic stone pieces, ceramic and coin finds were evaluated. In this article, brick rosette on the $\mathrm{K} 5$ place façade of the northern additional structure was mentioned, but the pattern was not subject to a detailed study. Brick rosettes are especially found on the façade of the capital Constantinople (İstanbul), Anatolia, Balkans, Greece and Aegean Islands in the Middle and Late Byzantine Period. This type of brick rosettes is seen on structures with various functions such as palace, church, episkopeion, tower, Castle and fountain. The fact that a similar pattern is common among Emirates Period and Early Ottoman Period structures causes a discussion that it was made by Byzantine masters as well as pointing out to continuity of the pattern. Similar brick ornaments were named in various ways by researchers such as 'rosette, sun pattern, symbol of light, sun disk, disk and round patterns'. In publications, it stands out that there is no consensus on the symbolic meaning, origin and chronology of the pattern.

In this study, brick rosettes on the façade of northern and north- annexes of St Nicholas Church are compared in detail with examples from different geographies. The brick rosette on the façade of north-eastern annexes of the church is important in that it is a unique example which is painted and in which the original pattern can be identified. In this regard, rosettes on the northern and north-eastern annexes present interesting conclusions. Our goal is to identify the origin and chronology of the pattern and present how the symbolic meaning of the motive that is thought to be originating from pagan beliefs was transformed in the Early Christianity Period with examples. In this regard, impacts of the Unconquered Sun/Sol belief, which has become popular in Rome as of 3rd century, on Christianity was discussed within the framework of researchers' views. We hope that the results would constitute a significant reference for similar studies on this subject that may be conducted in the future.
\end{abstract}

Keywords: Myra, Byzantine, St. Nicholas Church, brick rosettes, sun motif, Sol Invictus

\title{
Aziz Nikolaos Kilisesi Kuzey Ek Yapısı
}

Aziz Nikolaos Kilisesi kuzey ek yapısı ilk kez U. Peschlow tarafından, 1975 yılında "Myra" kitabında tanitılır. Araştırmacı, büyük oranda toprak altında olan kuzey ek yapının sadece beş mekânını görerek, yapıyı 12. yüzyıla tarihlendirmiştir¹. 1990 yılındaki başka bir makalesinde ise ek yapıların 1034-1087 yılları arasına inşa edilmiş olabileceğini belirtmiştir². Yapının banilerinin IX. Konstantin Monomakhos ve İmparatoriçe Zoe ile imparatorun erkek kardeşi Ioannes Orphanotrophos olabileceğini öne sürmüştür³.

Prof. Dr. S. Y. Ötüken tarafından 1989-2009 yılları arasında yürütülen kazı çalışmalarında, kuzey ek yapı tümüyle açığa çıkarılmıştır (fig. 1). Kuzey ek yapı A1-A3 ve K1-K6 olarak adlandırılan, $54.50 \mathrm{~m}$ uzunluğunda, açık ve kapalı dokuz bölümden oluşur. Kilise ile birlikte, 27.55 m uzunluğundaki, kuzeydoğu ek yapıyı (C, C1, C2) çevreler. Yapı, taş-tuğla renkli duvar örgüsü, kademeli kemerleri, tuğla süslemeleri ve zengin mimari plastik öğeleri ile Orta Çağ mimarisinin ünik örneklerindendir. S. Y. Ötüken, kuzey ek yapının Paleologoslar Dönemi'nde başkentte inşa edilen ek yapıların, 11. yüzyıldaki öncüsü olduğunu belirtir 5 . Araştırmacı, kuzey ek yapıyı IX. Konstantin tarafından 1042-54 yıllarında inşa edilen Aziz Georgios Kilisesi'nin kuzey ve batısındaki iki katlı yapılar, 13. yüzyıl Kilise Camii'nin güney ek yapısı ve batısındaki eksonarteks, ayrıca Enez Ayasofya Kilisesi'nin (Fatih Camii) 13-14. yüzyıla tarihlendirilen eksonarteksi ile karşılaştırır'́.

\footnotetext{
${ }^{1}$ Ek yapılar için bk. Peschlow 1975, 318, 344, 345 vd.

2 Peschlow 1990, 253.

${ }^{3}$ Peschlow 2000, 75-78.

4 S. Y. Ötüken, A1-A3, C, C1-C2 ve kuzey ek yapının mimarisini ayrıntılı olarak kazı sonuçları raporları ve ilgili makalede tanıtır. Burada sadece iki mekân üzerine yapmış olduğu değerlendirmeleri sunmaya çalışacağız. Bk. Ötüken et al. 1999/2000, 224-228.

5 Ötüken et al. 1999/2000, 227.

6 S. Y. Ötüken tarafından yayınlanan mimari değerlendirme için bk. Ötüken et al. 1999/2000, 224-228; Enez
} 


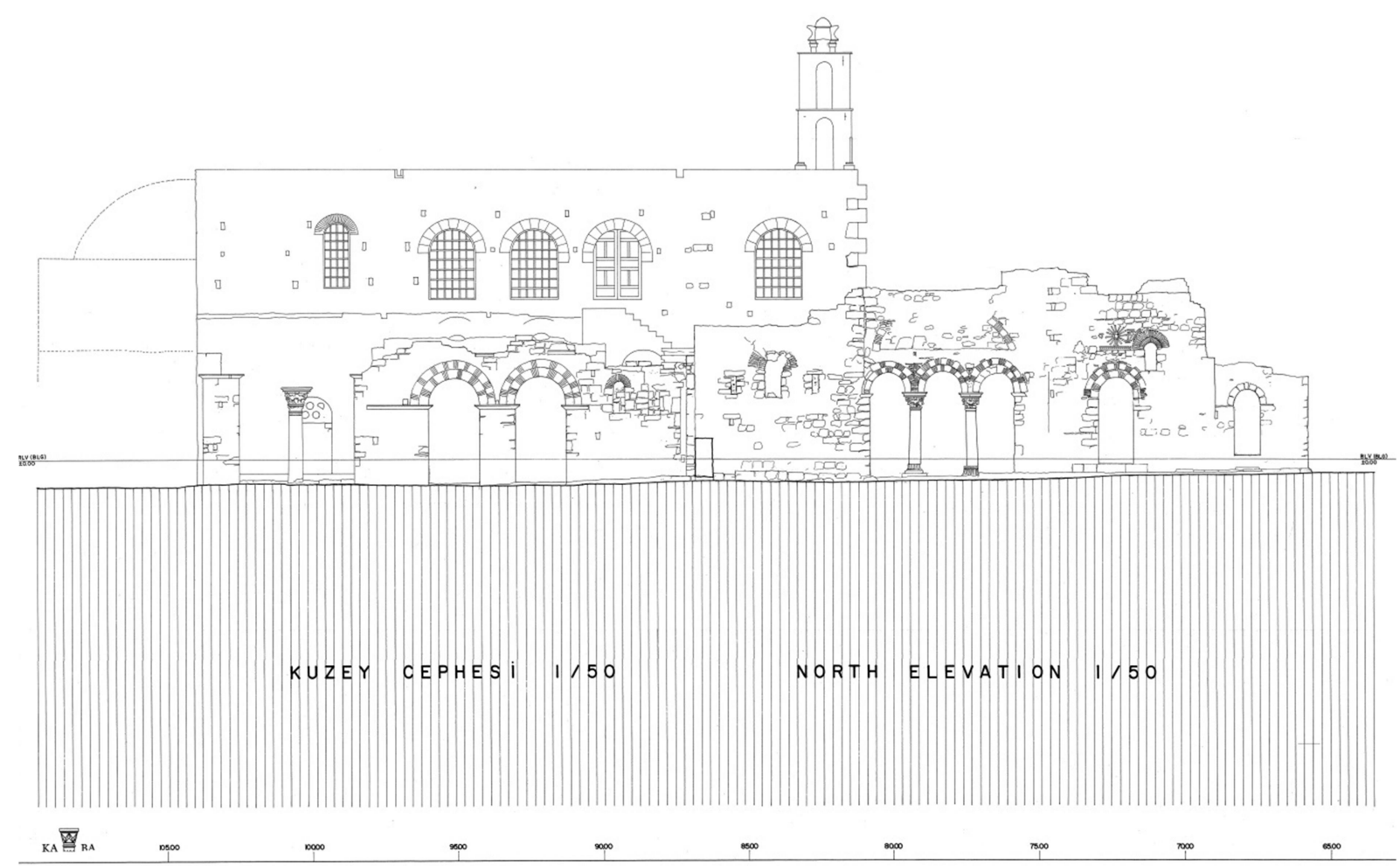

Figür 1: Aziz Nikolaos Kilisesi Kuzey Ek Yapı Cephesi

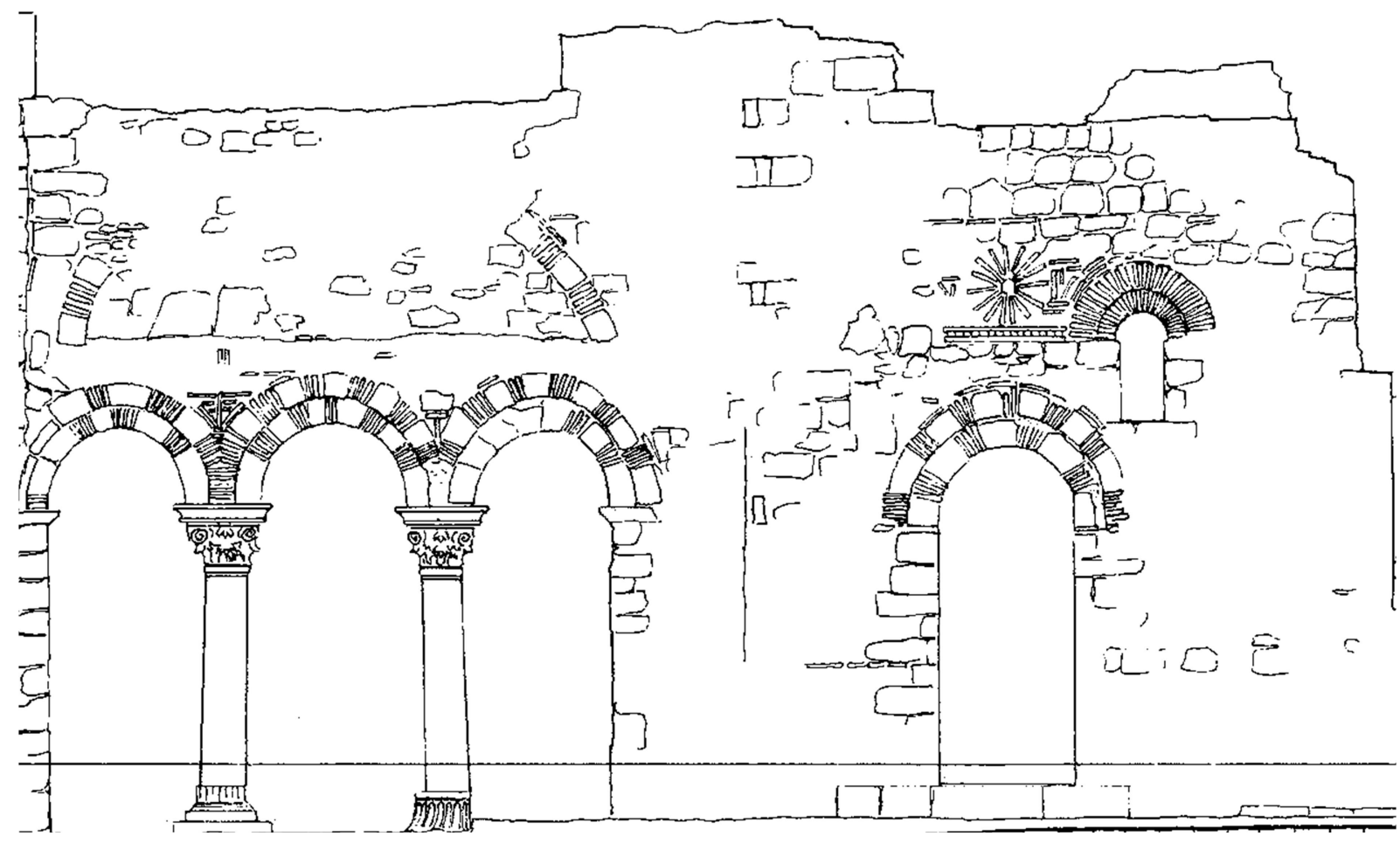

Figür 2: Aziz Nikolaos Kilisesi Kuzey Ek Yapısı K4-K5 mekânı cephesi

Ayasofyası eksonarteksi için ayrıca bk. Eyice 1969, 354. 
Kuzey ek yapının K4 mekânı beşik tonozlu, iki sütundan oluşan üçlü arkad düzenlemesi ile kuzeye açılan bir geçiş özelliği taşır. Arkadın yuvarlak, kademeli kemerleri bir sıra taş ve üç sıra tuğla ile almaşık teknikte yapılmıştır. Kuzey duvarın üst seviyesinde taş ve tuğladan almaşık teknikte örülmüş bir kör kemer bulunur (fig. 2-3). S. Y. Ötüken, taş ve tuğla örgülü kemerlerin 13. yüzyıl başkent mimarisinin karakteristik bir özelliği olduğunu belirtirken, Anadolu' da İznik Ayasofya'sının 1065 sonrası kubbe kasnağı ve Sakız Adası Nea Moni Kilisesi'ni (1042-45) erken örnekler olarak verir (fig. 4-5). Aziz Nikolaos Kilisesi kuzey eki ve Kekova Adası'ndaki bazilikada kemerler, başkentten farklı olarak yerel karakterde, taş ve tuğla üst üste getirilerek kaydırmalı teknikte örülmüştür 7 . Z. Mercangöz, Batı Anadolu' da Laskarisler ve Erken Osmanlı Dönemi eserlerinde almaşık teknikte kemer kullanımına değinirken, Kekova Adası'ndaki bazilika ve kuzey ek yapıdaki kademeli kemerlerden dolayı tekniği Anadolu kökenli olarak tanımlar8.

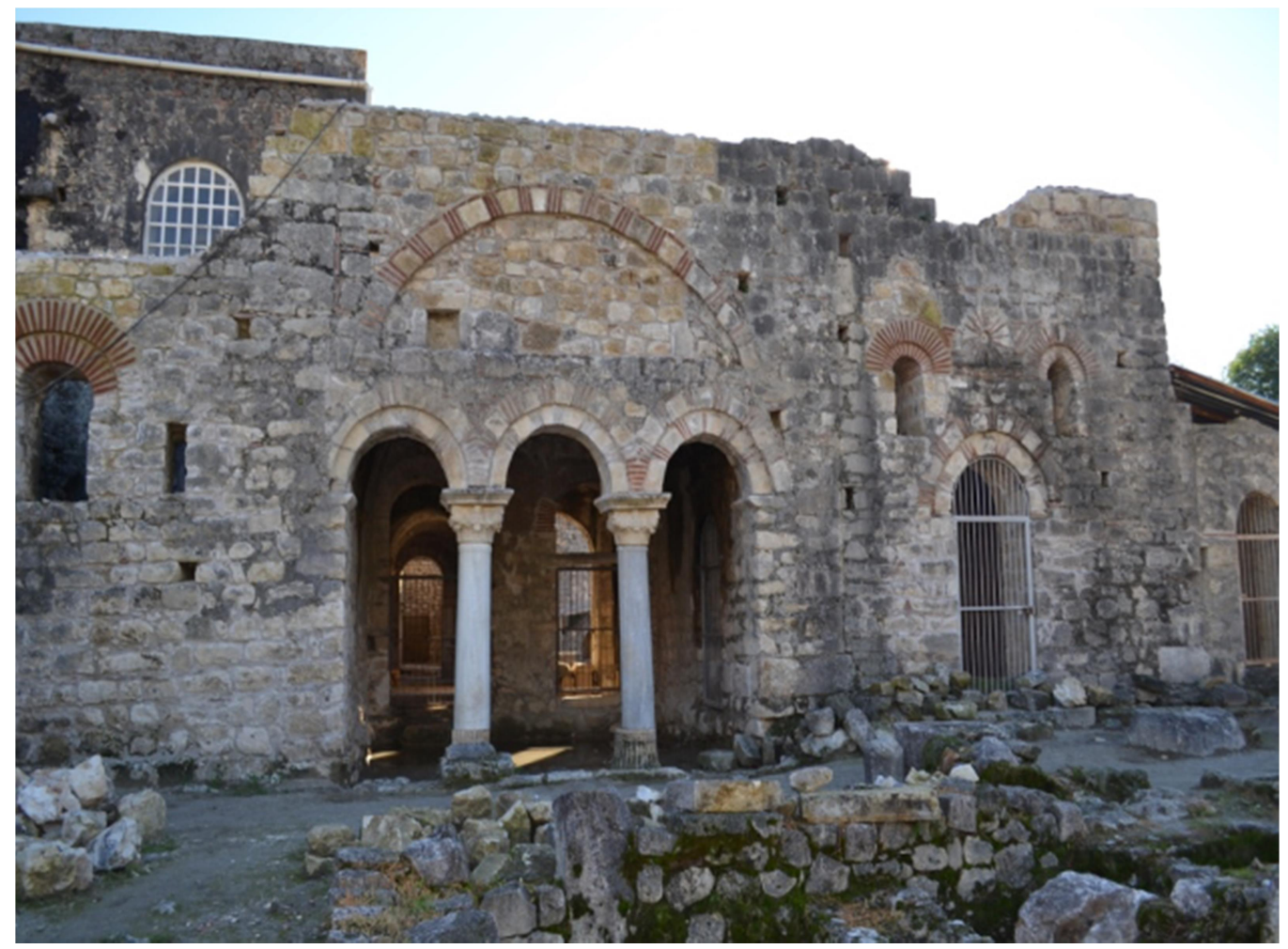

Figür 3: Aziz Nikolaos Kilisesi kuzey Ek Yapı 2012-2013 restorasyon çalışmaları sonrası

K4 mekânı arkadın doğu kemer köşesinde tuğlalar belirli bir düzende yatay ve dikey olarak yerleştirilmiştir (fig. 6). Bu düzenlemenin tam ortasındaki tuğlalar orijinalde bir haç motifi oluşturacak biçimde yerleştirilmiş olabilir. Benzer şekilde kemer köşesinde tuğladan haç motifi, 14. yüzyıl Sakız Adası Pirgi Kutsal Havariler Kilisesi'nde görülür9. K4 mekânındaki örnekte tuğlaların etrafında sıva ıslakken yapılmış çizgiler bulunur. Bu çizgiler tuğlaların rastlantısal konulmadığını, olasılıkla daha sonra görüleceği gibi orijinalinde boya ile yapılmış bir bezeme olabileceğini düşündürür. Batıdaki kemerler arasında ise birer dikey ve yatay tuğla bulunur (fig. 7). 11. yüzyılda cephede tuğla dekorasyondan söz edilebilmesi için her iki kemer köşesindeki tuğla dizilimin simetrik olması beklenir. Bu durumda batı kemer köşesinde yatay tuğla hizasından itibaren duvarın restorasyon geçirmiş olması olasidir.

\footnotetext{
7 Ötüken et al. 1999/2000, 228.

8 Mercangöz 1995, 488-489.

9 Fotoğraf için bk. “Aziz Apostoli Kilisesi,” 2020.
} 


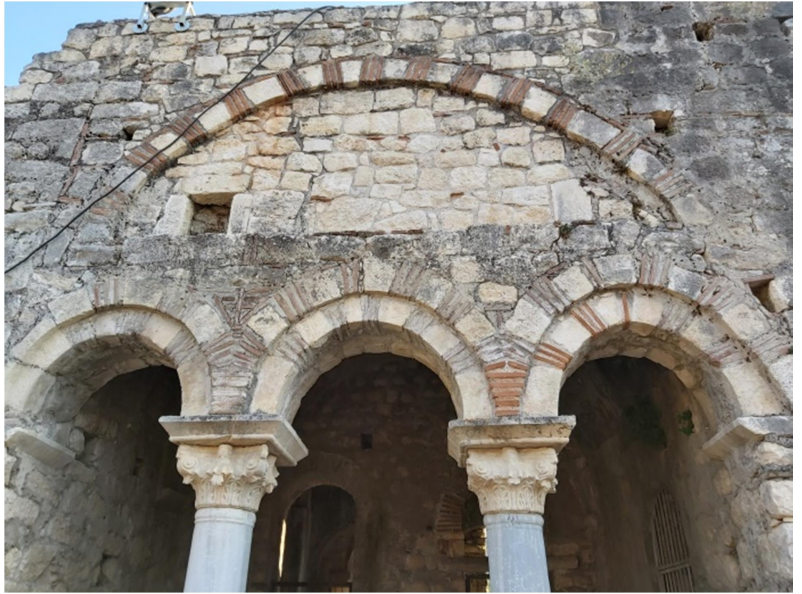

Figür 4: Aziz Nikolaos Kilisesi Kuzey Ek Yapı K4 mekânı

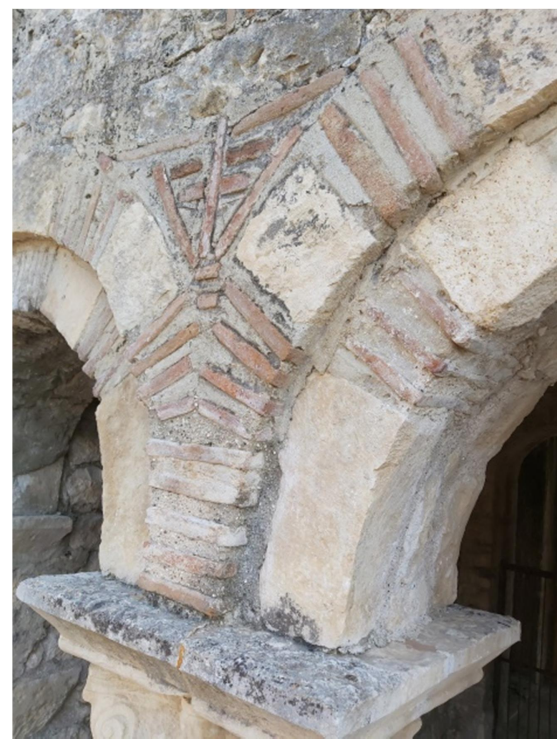

Figür 6: Kuzey Ek Yapı K4 mekânı arkad kemerleri tuğla bezeme

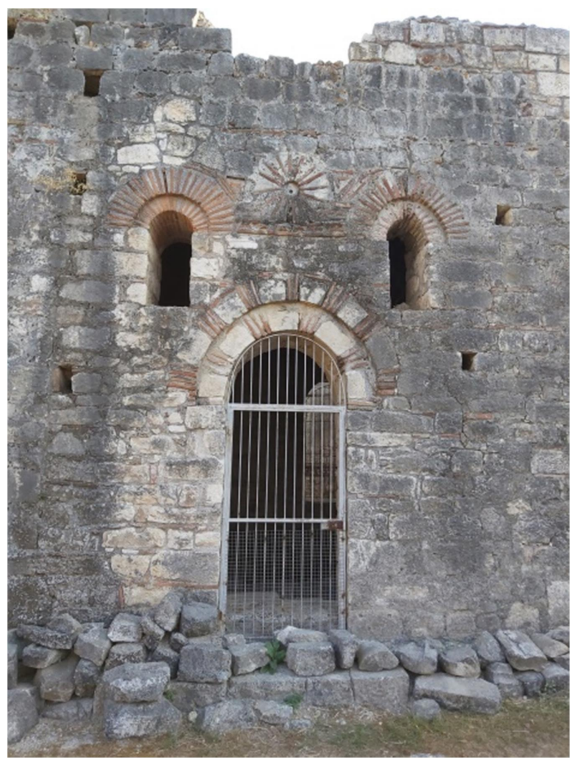

Figür 8: Kuzey Ek Yapı K5 mekânı

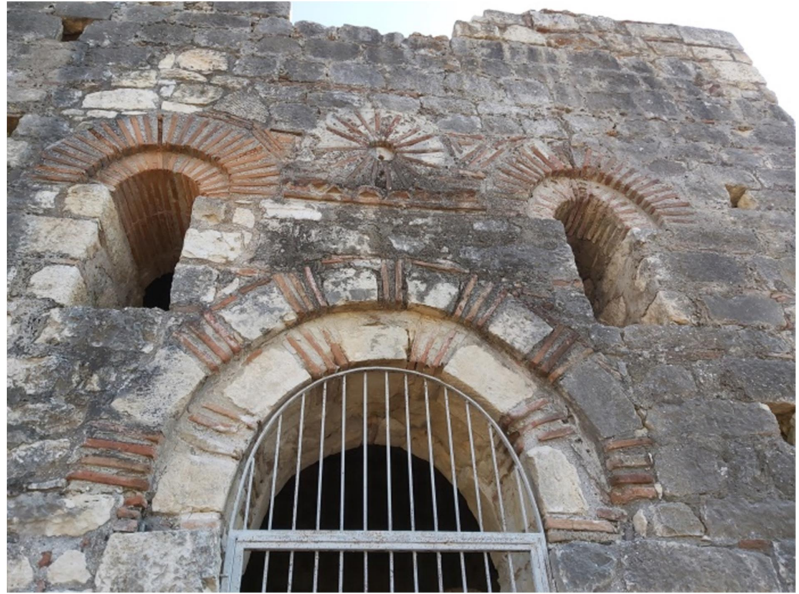

Figür 5: Aziz Nikolaos Kilisesi Kuzey Ek Yapı K5 mekânı kemerleri

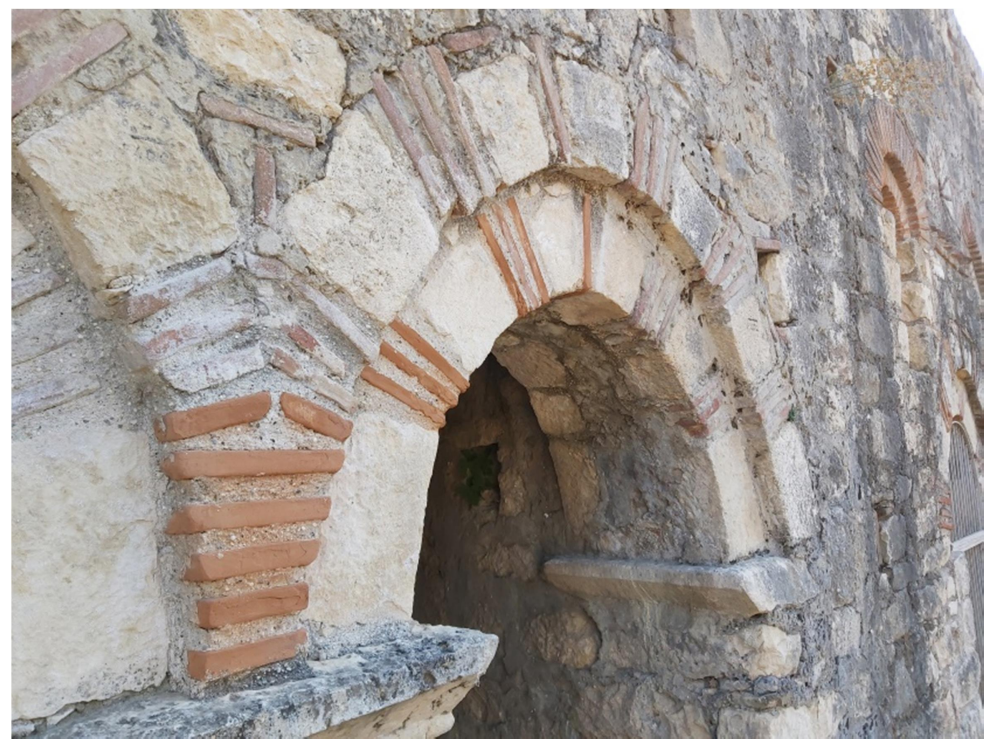

Figür 7: Kuzey Ek Yapı K4 mekânı arkad kemerleri

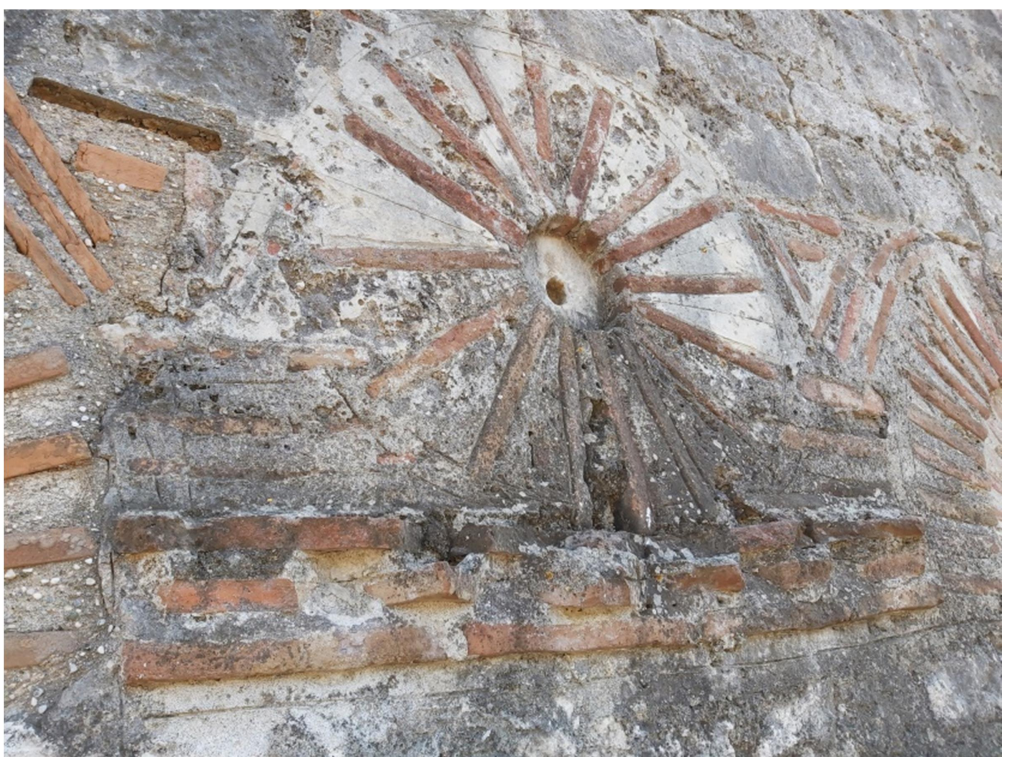

Figür 9: Kuzey Ek Yapı K5 mekânı tuğla rozet/güneş motifi 
Kuzey ek yapının K4 mekanına batıdan bitişik olan K5 mekanı, kuzeyde almaşık teknikte, kademeli yuvarlak kemerli kapı ve tuğla kemerli pencerelerle dişarı açılır ${ }^{10}$ (fig. 8). Kapının üzerinde tuğlalarla yapılmış bir zikzak/testere dişi frizi görülür ${ }^{11}$. Bu frizin üstünde 16 tuğlanın ışınsal şekilde yerleştirilmesi ile bir rozet/güneş motifi oluşturulmuştur (fig. 9). Motif incelendiğinde, iki tuğla arasındaki geniş dilimlerin sıva sslakken yapılan çizgilerle bölündüğ ü görülür. Bu dilimlerin sayısı ise 26 olarak belirlenmiştir. Rozet/güneş motifinin etrafını sıva ıslakken yapılmış $4-5 \mathrm{~cm}$ genişliğinde bir şerit çevreler; tam ortasında ise içbükey bir taş bulunur. Taşın ortasındaki küçük dairesel oyuk, bu kısma olasılıkla bezemeli başka bir parçanın yerleştirildiğini düşündürür (fig. 10).

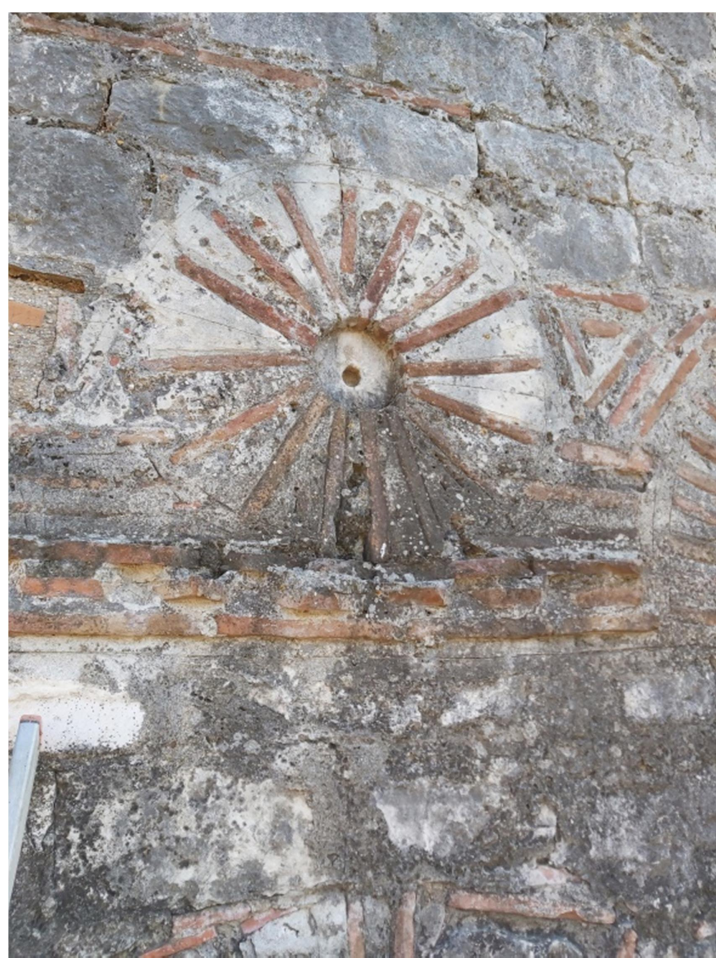

Figür 10: Aziz Nikolaos Kilisesi Kuzey Ek Yapı K5 mekânı tuğla rozet/güneş motifi

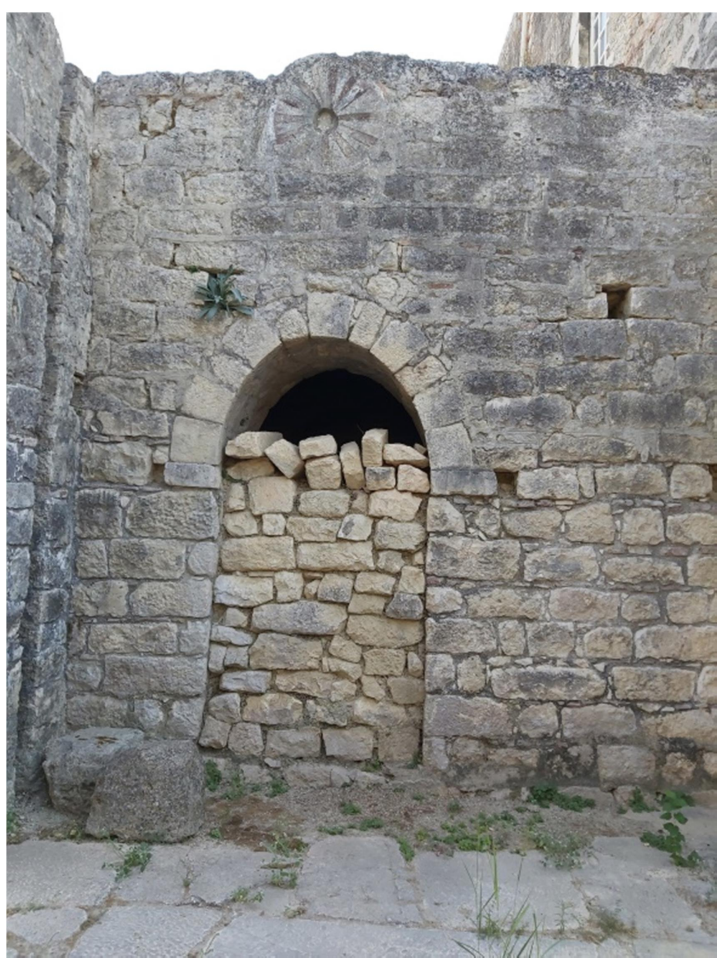

Figür 11: Aziz Nikolaos Kilisesi Kuzeydoğu Ek Yapı C2 mekânı rozet/güneş motifi

Kilisedeki bir diğer rozet/güneş motifi, kuzeydoğu ek yapının C2 mekânı kuzey cephesindeki kapının üzerindedir (fig. 11). K5 mekanında olduğu gibi motifi oluşturan ışınsal tuğlaların arası sıva islakken çizilerek ikiye bölünmüş, 26 dilimli bir rozet elde edilmiştir. K5 mekanındaki motiften farklı olarak dilimler, orijinalde kontrast oluşturacak şekilde, beyaz ve kırmızı renkte boyalıdır. Beyaz renkli ışınlar V şeklinde sivri uçla sonlanır (fig. 12). Rozet/güneş motifini çevreleyen şeritte kırmızı renkte boya ile yapılmış zikzak motifi ve aralarda noktalar görülür (fig. 13). Benzer örneğine rastlanılmayan boyalı rozetlerin tarihlendirilmesi tartışmalı olmakla birlikte, yalnızca Zeytinbağı/Tirilye'deki (Fatih Camii) kilisenin rozetinde tuğlaların boyalı olduğu sanılmaktadır ${ }^{12}$. Zikzak motiflerinin benzeri ise Sırbistan'da 13. yüzyıl kiliseleri ve İstanbul'da 1320 tarihli Khora Manastır Kilisesi'nde (Osmanlı Dönemi Kariye Camii) görülür13. C2 yapısındaki rozette kırmızı renkli dilimlerin

102012 yılında T.C. Kültür ve Turizm Bakanlığı ile Antalya Arkeoloji Müzesi denetiminde gerçekleştirilen restorasyon çalışmalarında kilisenin kuzey ek yapısında kör kemer ve K5 mekanındaki pencerelerden biri projeye uygun olarak yenilenmiştir. Bk. Doğan et al. 2013, 292-301.

11 Zikzak motifinin kökeni ve sembolik anlamı tartışmalı olmakla birlikte, köken ve kronoloji için bk. Kolay ve Erdoğan 2019, 241-256; sembolik anlamı için bk. Ćurčić 2012, 307-337.

12 Pekak 2009, 138, fig. 53

13 Ćurčić 2012, 320, 11.12. 
tuğla imitasyonu olduğu sanılmaktadır. Kurbinovo'da Aziz George Şapeli'nin (1185-1191) batı cephesinde duvar örgüsündeki çerçeveli teknik sıva yüzeyinde boyayla taklit edilmiştir ${ }^{14}$. Veljusa'daki Eleusa Meryem Kilisesi'nin dış cephesinde benzer şekilde alttaki tuğla örgü, üstte boya ile yapılmıştır ${ }^{15}$. C2 yapısındaki rozetin ortasına K5 örneğinde olduğu gibi içbükey bir taş yerleştirilmiştir ${ }^{16}$. İstanbul'da Philantrophos İsa Manastırı Kilisesi (Soteros) ve Pammakaristos Manastırı'ndaki (1310-1315) rozetlerde haç, Konstantin Lips Manastırı'nda (Fenari İsa Camii) ise çarkıfelek motifi bulunur ${ }^{17}$.

Aziz Nikolaos Kilisesi ek yapıları U. Peschlow ve S. Y. Ötüken tarafından 11.-12. yüzyıllara tarihlendirilir ${ }^{18}$. Kuzey ve kuzeydoğu ek yapıların cephesinde rozet/güneş motifleri malzeme ve teknik açıdan benzer olduğundan yaklaşık aynı döneme ait olmalıdırlar (fig. 14-15). Bununla birlikte her iki rozetin sıva yüzeyindeki çizgilerin benzer oluşu, K5 mekânındaki rozetin de orijinalde boyalı olduğunu düşündürür. Bizans mimarisinde yapıların diş cephesi orijinalde sıvalı, bazı örneklerde ise Aziz Nikolaos Kilisesi G yapısı ve Myra Şapeli'nde olduğu gibi freskoyla bezemeli olmalıdır. Nitekim Aziz Nikolaos Kilisesi'nin kuzeyde arkadla dışarı açılan A1, A2, A3 mekânlarında fresko izleri mevcuttur ${ }^{19}$. Balkanlar'da geç Orta Çağ kiliseleri arasında diş cephede duvar resmi ile bezemeli örnekler bilinmektedir ${ }^{20}$. Muhtemelen rozet motifinin görüldüğü diğer yapılarda sıva izleri yeterince incelenmemiş, gözden kaçmış ya da tümüyle yok olduğundan günümüze ulaşmamış olmalıdır. Bu nedenle Aziz Nikolaos Kilisesi C2 yapısının cephesindeki rozet/güneş motifi ünik bir örnek olarak değerlendirilir (fig. 16a-b).

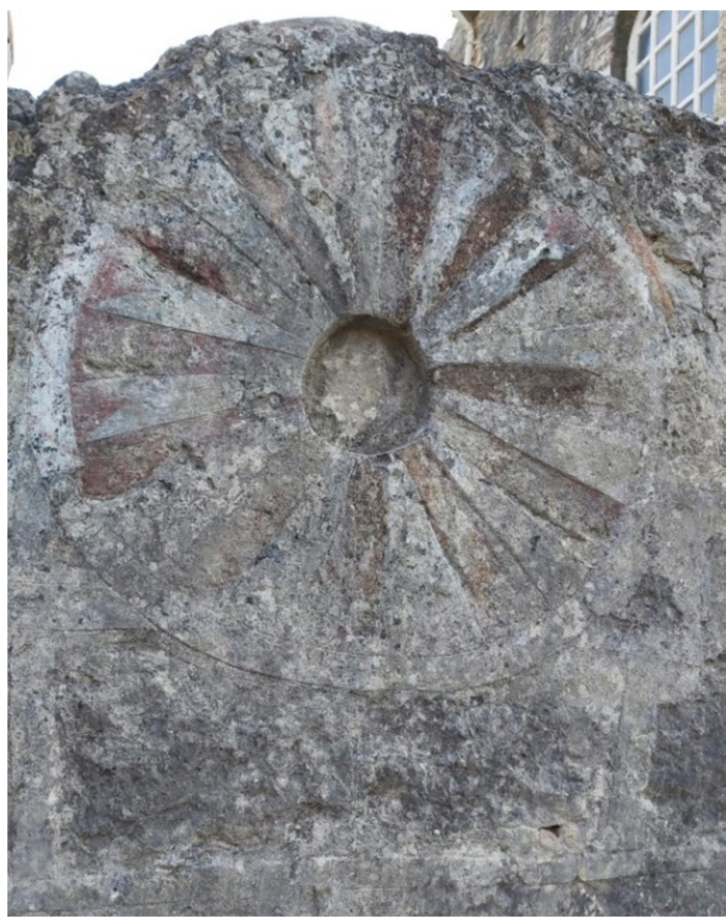

Figür 12: Aziz Nikolaos Kilisesi Kuzeydoğu Ek Yapı C2 mekânı rozet/güneş motifi

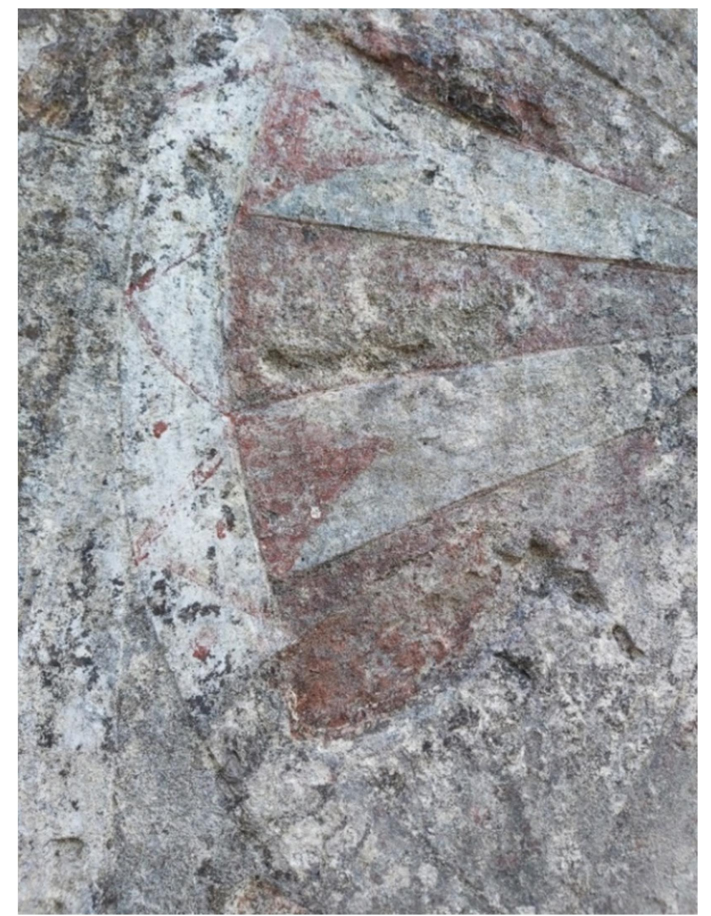

Figür 13: Aziz Nikolaos Kilisesi Kuzeydoğu Ek Yapı C2 mekânı rozet/güneş motifi detay

\footnotetext{
14 Epstein 1980, 200, 25.

15 Epstein 1980, 206, 31; ayrica bk. Miljkovik-Pepek 1981.

16 S. Y. Ötüken, kazılar sırasında bu kısımlarda Yunanistan'daki yapılarda olduğu gibi olasılıkla sırlı tabak olabileceğinden bahsetmiştir.

17 Kalfazade 1987, 15.

18 Peschlow 1975, 318, 344, 345 vd.; Peschlow 1990, 253; Peschlow 2000, 75-78; Ötüken 1997a, 79; Ötüken et al. 1999/2000, 221-242.

${ }^{19}$ G yapısı için bk. Doğan et al. 2019, 366-368, 380, fig. 6; Myra şapeli için bk. Akyürek 2015, 14-23.

20 Jevtić 2019, 318-325.
} 


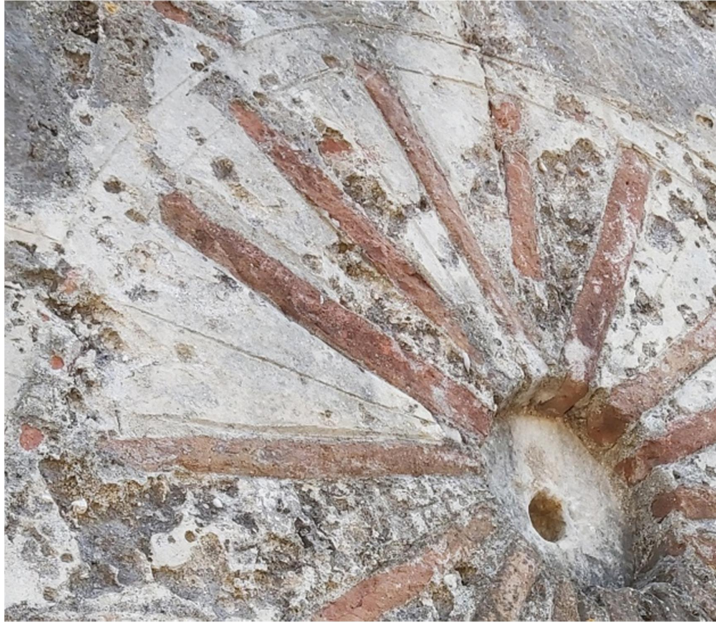

Figür 14: Aziz Nikolaos Kilisesi Kuzey Ek Yapı K5 mekânı rozet/güneş motifi detay

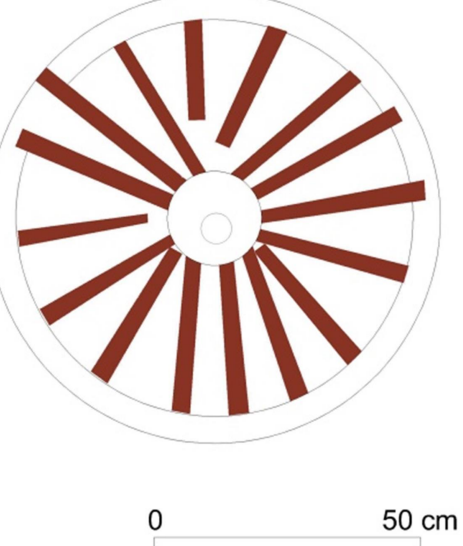

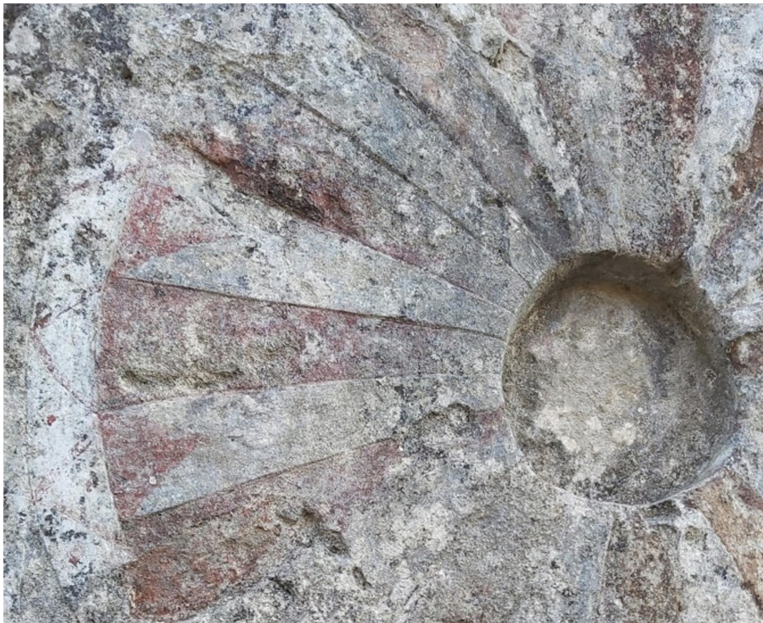

Figür 15: Aziz Nikolaos Kilisesi Kuzeydoğu Ek Yapı C2 mekânı rozet / güneş motifi detay

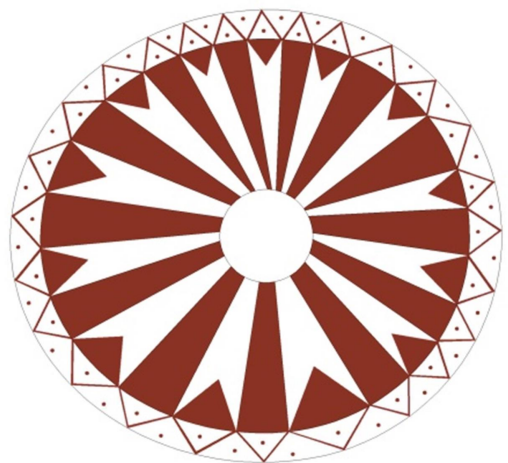
$150 \mathrm{~cm}$

Figür 16a-b: K5 ve C2 Yapısı rozet/güneş motiflerinin çizimi (Dijital çizim İ. Gültekin)

\section{Karşılaştırmalı Değerlendirme}

Orta ve Geç Bizans Dönemi'nde özellikle başkent Konstantinopolis (İstanbul), Anadolu, Balkanlar, Yunanistan ve Ege adalarındaki yapıların cephesinde tuğladan yapılmış ışınsal bezemelerle karşılaşılır. İstanbul'da 5. yüzyılın ortalarına tarihlendirilen Studios Manastırı Aziz Ioannes Prodromos Kilisesi'nin (İmrahor Camii) atrium kuzey duvarında, tuğladan yapılmış haç motifi ile iki tane rozet/güneş motifi bulunur ${ }^{21}$ (fig. 17). Ioannes Prodromos Kilisesi ve atriumun malzeme-teknik açıdan benzer olması, aynı dönemde inşa edildiğini düşündürür ${ }^{22}$. Studios Manastırı atrium kuzey duvarında bulunan rozetler, Bizans kiliselerindeki en erken tarihli örnekler olarak kabul edilir²3.

Likya Bölgesi'nde tuğla rozet motiflerinin görüldüğ̈ü bir diğer örnek, Olympos antik kentindeki episkopeiondur. Buradaki rozetler triclinium (yemekhane) kuzey duvarında kismen korunmuş durumda, kuzey duvarının doğu bölümünde ise sağlam şekildedir. Işınsal tuğla rozetlerin ortasında kilisedeki örneğimiz gibi içbükey bir oyuk bulunur ${ }^{24}$. Tricliniumun batı duvarında ise tuğladan bir haç motifi yer almaktadır ${ }^{25}$. Peristyl çeşmesinin anıtsal

${ }^{21}$ Fotoğraf için bk. “İmrahor İlyas Bey Camii,” 2020.

22 Tuğla rozet hakkında bilgi ve fotoğrafı için bk. Öztaşkın 2015, 619.

23 Öztaşkın 2015, 619, 627, fig. 14

24 Öztaşkın 2015, 625, fig. 9-10.

25 Öztaşkın 2015, 623, fig. 6. 
cephesindeki tuğla rozetler, aynı cephedeki tuğladan yapılmış Latin haçı bezemeli duvarın üst seviyesinde bulunmaktadır ${ }^{26}$. Olympos'taki tuğla rozetler kilisedeki örneklerimizden farklı olarak tuğla bir şeritle çevrelenmiştir. G. K. Öztaşkın, Olympos'taki episkopeionun tuğla süslemeleri ile birlikte değerlendirdiği rozetleri, yapıların inşa edildiği Erken Bizans Dönemi'ne tarihlendiririr27.

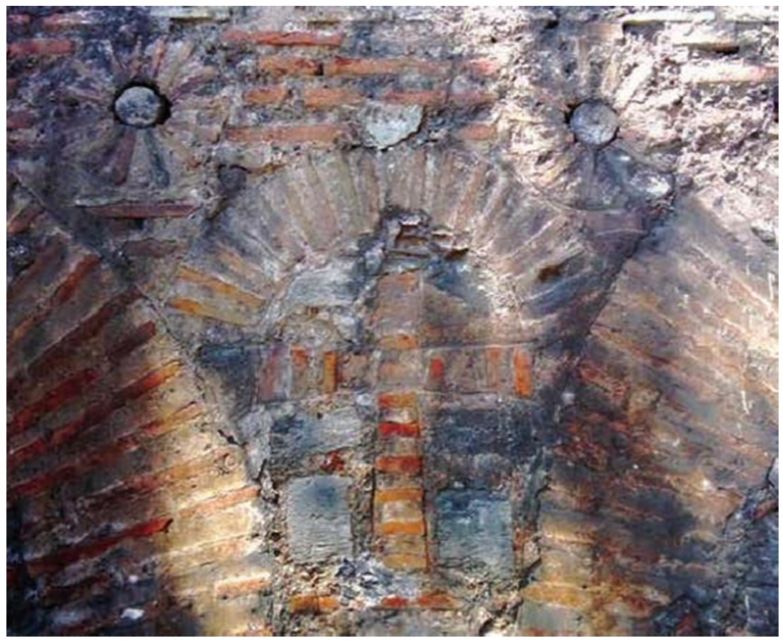

Figür 17: Studios Manastır Kilisesi atrium kuzey duvarındaki rozet ve haç motifi

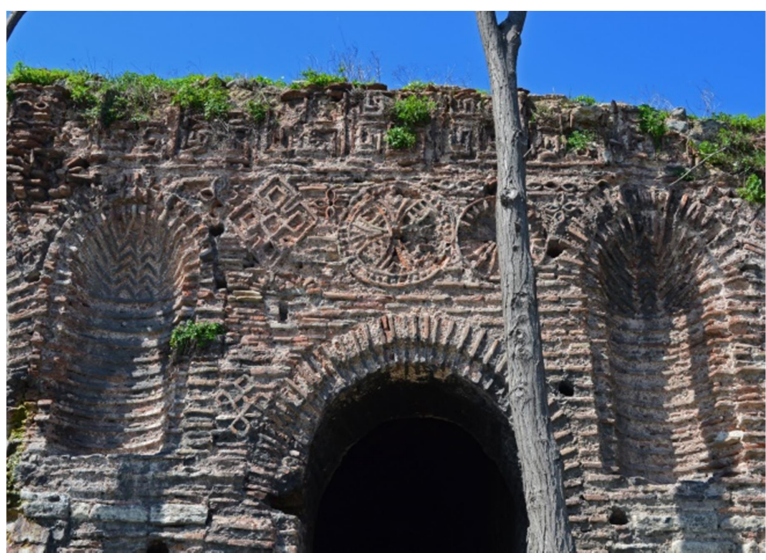

Figür 19: Philantrophos İsa Manastırı Kilisesi alt yapısı doğu cephe

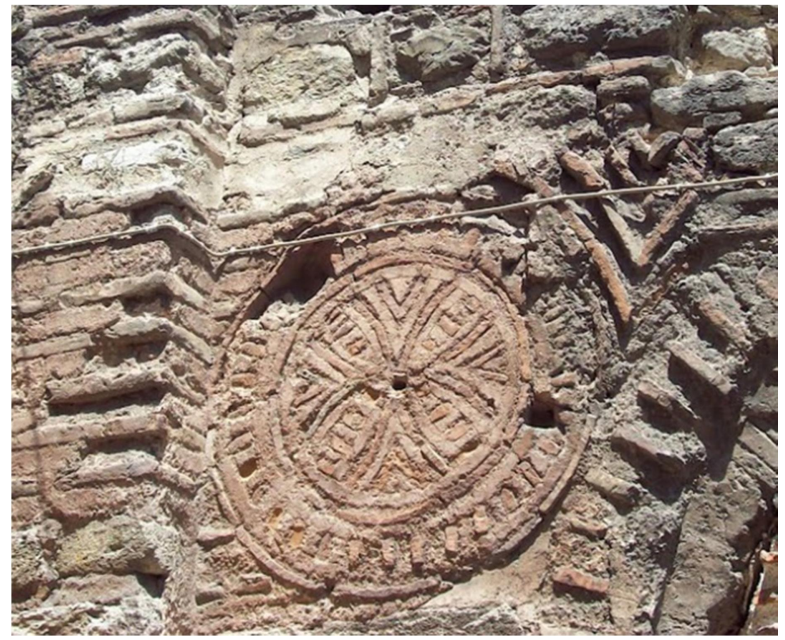

Figür 18: Pantepoptes Manastır Kilisesi (Eski İmaret Camii) rozet motifi detay 1

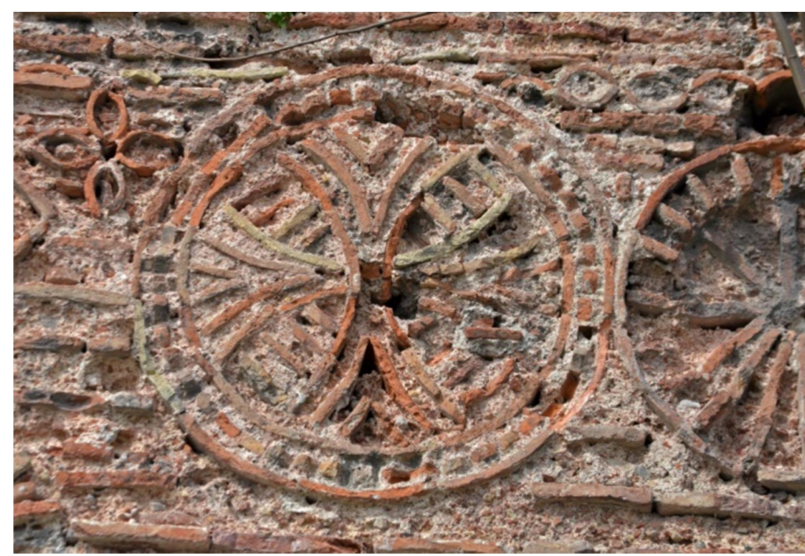

Figür 20: Philanthropos İsa Manastırı Kilisesi alt yap1 rozet motifi detayı

Bizans coğrafyasının genelinde olduğu gibi İstanbul'da, Studios Manastırı' ndan sonra inşa edilen yapılarda, rozet/güneş motifi mevcut yapılar üzerinden değerlendirileceğinden, rasyonel bir sonuç sunmak güçtür. Komnenoslar Dönemi yapılarında cephede artan tuğla kullanımı, aynı yüzyılda imparatorluğun diğer bölgelerinde başkent etkisi olarak görülür28. 11. yüzyılda I. Aleksios Komnenos Dönemi Pantepoptes Manastır Kilisesi (Eski İmaret Camii, 1081-1087) güney cephesinde madalyon içinde tuğladan bir haç motifi bulunur ${ }^{29}$ (fig. 18). Madalyonu çevreleyen şeritte ise özel olarak üretilmiş dikey tuğlalar yerleştirilmiştir. Haç motifinin paraleli İstanbul'da, Marmara kıyısında 12. yüzyıl Philantrophos İsa Manastırı Kilisesi'ne ait olduğu düşünülen, alt yapının doğu cephesinde yer almaktadır30 (fig. 19).

26 Öztaşkın 2015, 625, fig. 9-10, 626, fig. 12.

27 Öztaşkın 2015, 619.

28 Ötüken 1978; Ötüken et al. 1999/2000.

${ }^{29}$ Fotoğraf için bk. "Eski İmaret Mosque," 2020. Yapı için bk. Freely ve Çakmak 2005, 168-171.

30 Fotoğraf için bk. "Monastery of Christ Philanthropos," 2020. 
Tuğladan yapılmış rozetlerin en iyi örneklerini barındıran yapıda, ortasında haç motifi bulunan madalyonun yanında, aynı işçilikte ince tuğlalardan yapılmış bir rozet/güneş

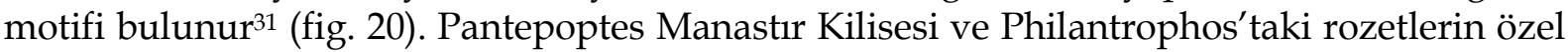
imalat tuğladan yapılmış olması ve işçiliği, başkent mimarisinde cephede tuğla kullanımına verilen öneme işaret eder ${ }^{32}$. Gebze, Eskihisar Kalesi'ndeki bir yapının batı cephesinde başkent örnekleriyle paralel şekilde, merkezinde haç olan madalyonun etrafını, dikey tuğla dizileri ile bezemeli bir şerit çevreler ${ }^{33}$.

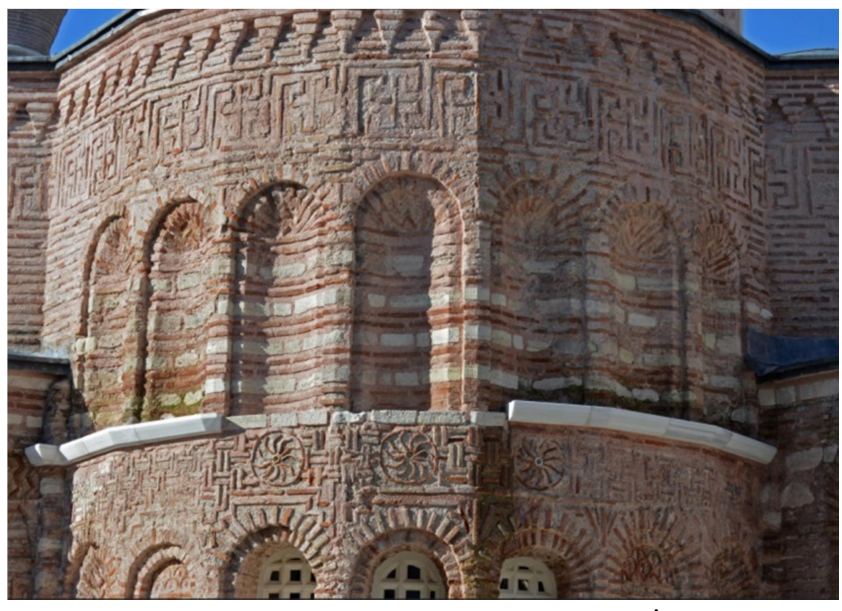

Figür 21: Konstantin Lips Manastırı (Fenari İsa Camii) Güney Kilisesi doğu cephe

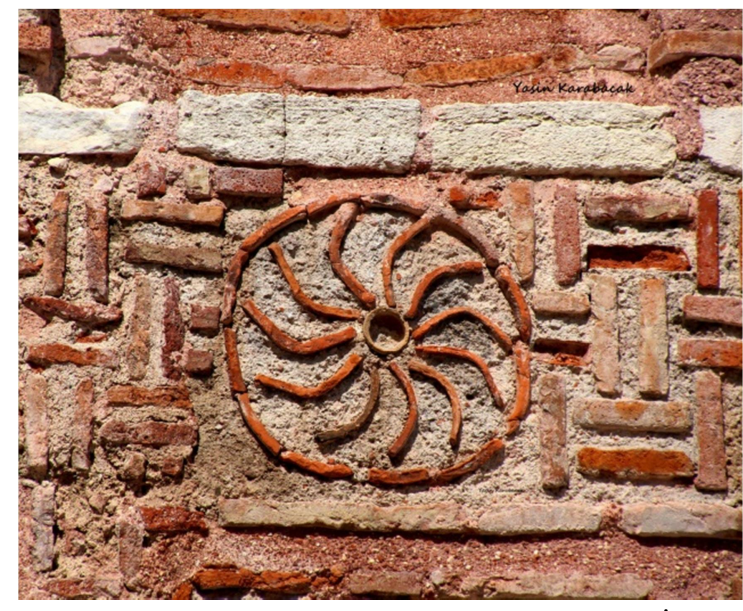

Figür 22: Konstantin Lips Manastırı (Fenari İsa Camii) Güney Kilisesi rozet motifi detayı

İstanbul'da tuğla rozet/güneş motiflerinin farklı bir uygulaması Konstantin Lips Manastırı (Fenari İsa Camii, 907) Aziz Ioannes Prodromos Güney Kilisesi'nin (1281-1304) doğu cephesindedir (fig. 21). Doğu cephedeki pencerelerin üzerinde çarkıfelek motifi olan üç rozet bulunur. Rozetler başkentteki diğer örnekler gibi özel üretim tuğladan (veya ince kiremit) yapılmış olup, ortasında yuvarlak bir süs çömleği yerleştirilmiştir ${ }^{34}$ (fig. 22). Sakız Adası'nda 11. yüzyıla tarihlenen Nea Moni Manastır Kilisesi'nin cephesinde benzer şekilde bir çarkıfelek motifi görülür ${ }^{35}$ (fig. 23). Ayrıca aynı cephede kare bir çerçevenin içinde ortada ışınsal bir rozet motifi, çerçevenin kenarlarında ise dört yönde tuğladan yapılmış ışınsal demetler bulunur. Yapının bir diğer cephesindeki kör kemer köşesinde ise tuğladan rozet/güneş motifi ve bir haç motifi dikkati çeker ${ }^{36}$. Pammakaristos Manastırı (Fethiye Cami) Güney Kilisesi'nin (1310-1315) cephesinde simetrik olarak yerleştirilmiş iki rozet bulunur (fig. 24). Kemer köşesindeki rozetler içbükey forma sahiptir. Her iki rozetin merkezinde tuğla ile kontrast oluşturan, beyaz renkte taştan bir haç motifi bulunur (fig. 25). Bu rozetler başkent yapılarında olduğu gibi özel üretim taş ve tuğladan yapılmıştır ${ }^{37}$. Benzer şekilde içbükey 1şınsal rozetler, Yenişehir Seyyid Mehmet Dede Zaviyesi'ndeki örnekte olduğu gibi Erken Osmanlı mimarisinde de devam eder ${ }^{38}$. S. Kalfazade, İstanbul' da Bizans mimarisinde görülen ışınsal bezemeleri şöyle tanımlar: "Fenari İsa Camii güney kilisesinin apsis cephesiyle, Soteros Kilisesi alt yapısının cephesinde gördüğ̈̈mü̈ tuğla rozetler, son devrin tipik, hareketli, dişa dönük cepheleriyle tam bir bütünlük oluşturmakta, bu bütünlük onlarn genel kompozisyon içinde

\footnotetext{
31 Yapı için bk. Freely ve Çakmak 2005, 164-165, 95; Mathews 1976, 202, 359.

32 Eyice 1963; Ötüken 1990, 395-403; Ötüken 1978, 213-233. vd.

33 Bahar 2013, 28, fig. 61.

34 Fotoğraf için bk. "Monastery of Lips," 2020. Ayrıca Macridy 1964, fig. 4; Mathews 1976, 202, 359.

${ }^{35}$ Fotoğraf için bk. "Nea Moni - Chios," 2020.

36Fotoğraflar için bk. "Nea Moni," 2021.

37 Kalfazade 1987, 12.

38 Kalfazede 1987, 15.
} 
algılanmalarına neden olmaktadır" 39 . İstanbul'da mevcut yapilarda görülen tuğla rozetler, üslup farklılıklarına rağmen motifin 5.14. yüzylllar arasında sürekliliğine işaret eder.

S. Y. Ötüken ve R. Ousterhout, Bolu yakınlarındaki 11. yüzyıla tarihlendirdikleri Çeltikdere Seben Kilisesi'nde benzer şekilde tuğladan işınsal bir rozet olduğundan söz ederler ${ }^{40}$ Araştırmacilar makalede motifi şöyle tanımlar: "Pencerelerle birlikte yerleştirilmiş tuğla yuvarlak, 11. yy.da Myra'da

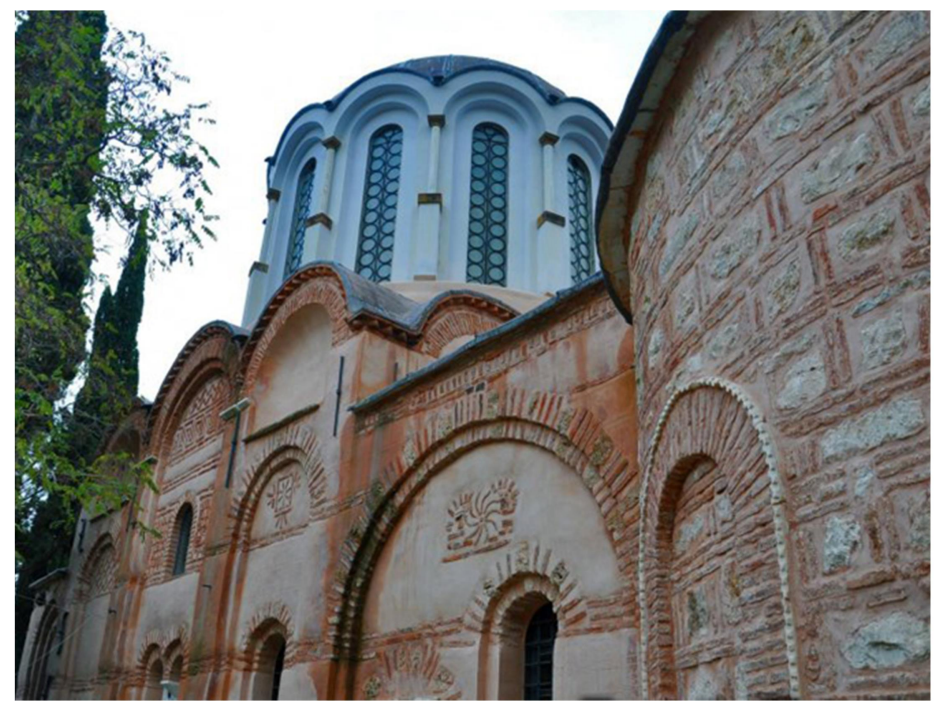

Figür 23: Sakız Adası Nea Moni Manastır Kilisesi

Aziz Nikolaos, Latmos, Kahve Asar adası ve İkiz Ada'daki iki kilise ile İslamköy'de kilisenin duvarlarında ve Tirilye'de Fatih Cami'nin tamburunda görülebilmektedir. Yuvarlaklar daha sonra Theotokos tou Libos'un doğu cephesinde, Philantropos Deniz Duvan ve Pammakaristos pareklesionunun güney cephesinde olduğu gibi başkentte görülür"41. Kuzey cephedeki ikiz pencere açıklığının hemen üstünde yer alan rozet motifi, taş ve tuğla almaşık tekniğindeki yapıyla bütünleşen bir görsellik oluşturur.

Laskarisler Dönemi'nde özellikle Batı Anadolu'daki yapıların cephesinde tuğla rozetler dikkati çeker. S. Y. Ötüken, bu bölgede yaptığı çalışmalarda Bafa Gölü'nde (Latmos) Kahve Asar Adası'ndaki Büyük Kilise'nin (8 Nolu) cephesinde bulunan tuğla rozetleri "güneş motifi" olarak tanımlar². Tuğlaların radyal biçimde yerleştirildiği bezemenin orta kısmında içbükey bir oyuk bulunur ${ }^{43}$. Bafa Gölü çevresindeki 11.-12. yüzyıla ait kiliselerdeki rozet motifleri, uslup ve malzeme tekniği açısından Aziz Nikolaos Kilisesi'ndeki örnekten (K5) farklı görülürler ${ }^{44}$. S. Y. Ötüken, Bafa Gölü'ndeki yapıların cephe süslemelerinde başkent etkisinden ziyade Sart (E Kilisesi) ve Yunanistan'daki yapılarla benzerlikten söz eder ${ }^{45}$.

Bafa Gölü çevresinde Laskarisler Dönemi mimarisi üzerine geniş kapsamlı çalışmalarda bulunan H. Buchwald, Kahve Asar Adası'ndaki Büyük Kilise'nin (8 Nolu) güney cephesindeki pencerelerin köşesi ve arkad kemerleri üzerindeki rozetlere değinir ${ }^{46}$. Benzer şekilde İkiz Ada' da Bakire Meryem Kilisesi'ndeki (4 Nolu) birden fazla rozete dikkati çeker ${ }^{47}$. Ayrıca Eğri Dere Kilisesi'ndeki kör arkad kemerleri arasında benzer şekilde tuğladan 1şınsal bir rozet olduğunu belirtir ${ }^{48}$. Z. Mercangöz, Bafa Gölü'nde Orta Bizans Dönemi kilise mimarisinin örneklerinden olan Kirselik'teki Manastır Kilisesi'ni 9.-11. yüzyıllara, ek yapısını

${ }^{39}$ Kalfazade 1987, 14.

40 Ötüken ve Ousterhout 1995, 85-92, fig. 9.

41 Ötüken ve Ousterhout 1995, 91, fig. 8-9; Bununla birlikte 2017 yılında yapıyla ilgili bir yayında olasılıkla günümüze gelmediğinden tuğla bezemeden bahsedilmez. Bk. Verim 2017, 235-256.

42 Ötüken 1978, 225, fig. 25.

43 Latmos'taki kiliseler için bk. Ötüken 1978, 225, fig. 25; Buchwald 1979, fig. 10, 12, 14; Ötüken ve Ousterhout 1995, 91; Mercangöz 1990, 117-138, lev. 21-26, 125, fig. 3, lev. 24, fig. 7, lev. 26, fig. 11-12; Mercangöz 1995, fig. 1-7.

44 Ötüken et al. 1999/2000, 228.

45 Ötüken 1978, 220.

46 Buchwald 1979, fig. 10, 12, 14; Buchwald 1999, 270-271.

47 Buchwald 1999, 273; Öztaşkın 2015, 626, fig. 12.

48 Buchwald 1999, 274; Öztaşkın 2015, 626, fig. 12. 
ise 13. yüzyıla tarihlendirir ${ }^{49}$. Eksonarteks güney cephesi kemer köşesindeki 1şınsal bezemeyi "güneş motifi" olarak tanımlar50. Benzer örneğin Kahve Asar Adası'nda 13. yüzyıla tarihli yapının kuzey haç kolu pencere kemerleri üzerinde olduğunu belirtir ${ }^{51}$. Bafa Gölü'ndeki rozetlerin erken tarihli bir örneğinin, Zeytinbağı/Tirilye' deki (Osmanlı Dönemi Fatih Camii) kilisenin kubbe kasnağında olduğunu söyler ${ }^{52}$.

Bursa Zeytinbağ1/Tirilye'deki kilisenin kubbe kasnağının üst seviyesinde, 1şınsal bir rozet/güneş motifi bulunur. Bir fotoğrafında, rozeti oluşturan tuğlalar üzerinde boya kalıntısı görülür. Rozetin hemen yanında ise duvar örgüsünde, olasılıkla palmiye dalı bezemeli devşirme bir parça dikkati çeker ${ }^{53}$. Kasnaktaki bu bezeme Studios Manastırı'ndaki rozet motifini, bitkisel bezemeli parça ise Selanik oktagonundaki palmiyeleri çağrıştırır ${ }^{54}$. Ayrıca Bursa Yıldırım Darüşşifası'nda tuğladan yapılmış rozet, testere dişi ve palmiye dalı motifi aynı cephede uygulanmıştır ${ }^{55}$. Yapı ustaları olasılıkla rozet ve palmiye dalının sembolik olarak birlikte kullanımına yönelik, geçmişten gelen ortak bir belleğe sahip olmalıdır. Bununla birlikte S. Pekak, kasnaktaki tuğla süslemelerin 19. yüzyıldaki onarımlarda yapılmış olduğunu ileri sürer ${ }^{56}$. 19. yüzyıldaki uygulamaların tarihlendirme açısından tartışmalı olması ayrıca; Komnenoslar Dönemi örnekleri ile paralelliği göz önüne alındığında, kasnaktaki rozet motifinin yapının 11. yüzyılda geçirdiği onarıma ait olabileceği göz ardı edilmemelidir ${ }^{57}$.

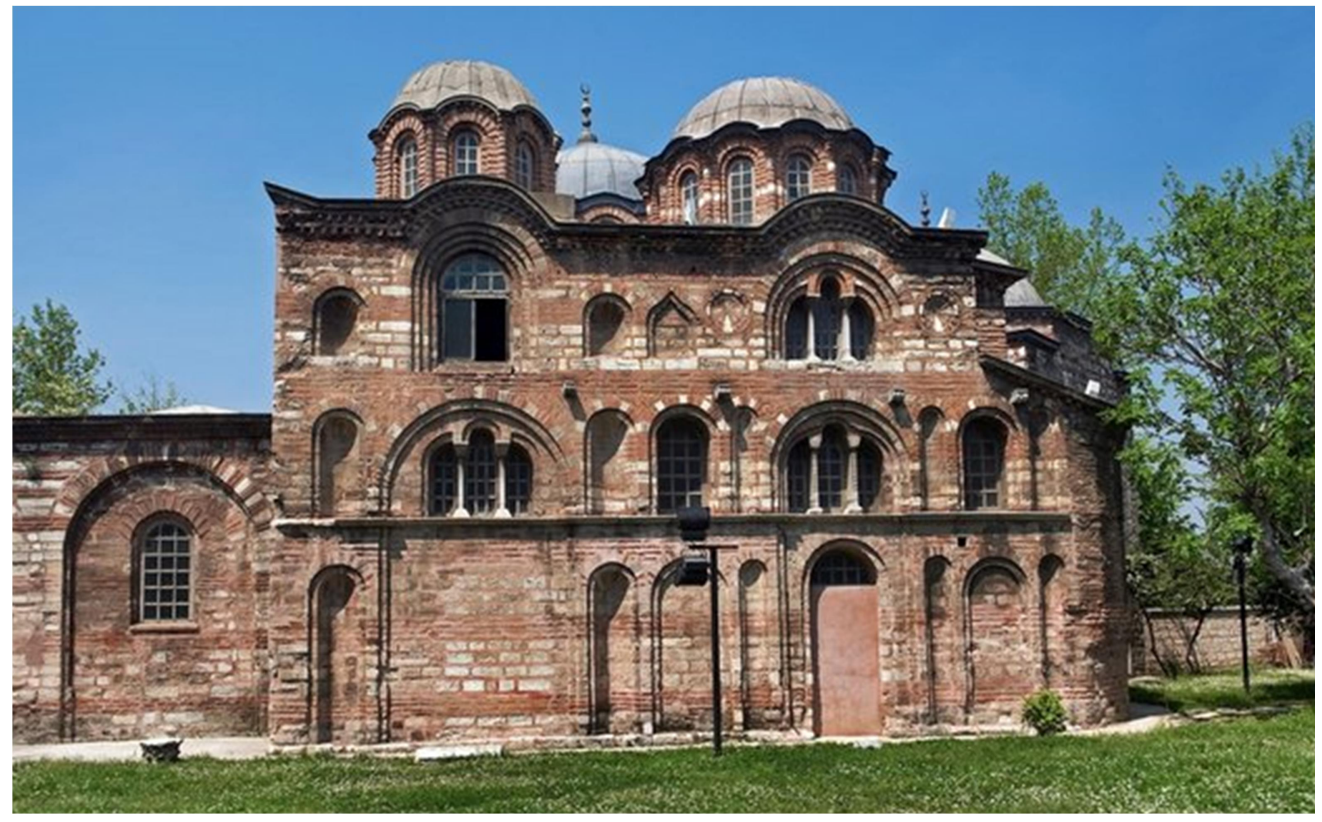

Figür 24: Pammakaristos Manastırı Güney Kilisesi

Karşılaştırma verileri içerisinde şüphesiz en dikkati çeken örnek, Konya'da Sille Aya Elena Kilisesi'nin silindirik kubbe kasnağındaki tuğla rozetlerdir ${ }^{58}$ (fig. 26). İ. M. Mimiroğlu

\footnotetext{
49 Mercangöz 1990, 117-138.

50 Mercangöz 1990, 125, fig. 3, lev. 24, fig. 7.

51 Mercangöz 1995, 492, fig. 2.

52 S. Pekak kiliseyi 9. yüzy1l sonuna tarihlendirir. Bk. Pekak 2009, 166.

53 Pekak 2009, 138, fig. 53.

54 Tuğla rozet bezeme ve fotoğrafı için bk. Öztaşkın 2015, 619; Vickers 1973, 114, fig. 9.

55 Mercangöz 1995, 492, fig. 1-2.

56 Pekak 2009, 138.

57 Onarımlar için bk. Pekak 2009, 141.

58 Sille Hagios Mikhael Kilisesi kubbe kasnağındaki güneş motifi bilgisi ile fotoğrafını kullanmamıza izin veren Dr. Öğr. Üyesi İ. M. Mimiroğlu'na teşekkür ederim. Sille Aya Elena Kilisesi ile ilgili yayını dolayısıyla Prof. Dr. S.
} 
kasnaktaki işınsal tuğla bezemeleri "güneş motifi" olarak tanımlar59. Kilisenin kasnağındaki tuğla süslemeler üç şerit halinde yapılmıştır. Ortadaki şeritte tuğladan dikey zikzaklar arasında 12 tane rozet/güneş motifi bulunur ${ }^{60}$. Üstteki şeritte tuğla zikzaklar, altta ise balık sirtı (tekli chevron) motifi tekrarlanmaktadır61. Kasnaktaki rozet/güneş motifleri Aziz Nikolaos Kilisesi'ndeki rozetlerden farklı olmakla birlikte, incelediğimiz diğer örneklerle benzerlik gösterir. Bununla birlikte rozet ve zikzak motifinin bir arada kullanımı açısından her iki yapı da Orta Çă̆'a özgü ortak bir repertuara sahip görünür.

Sille Aya Elena Kilisesi'nin tarihlendirilmesi konusunda araştırmacıların farklı görüşleri bulunmaktadır. S. Eyice, yapının erken

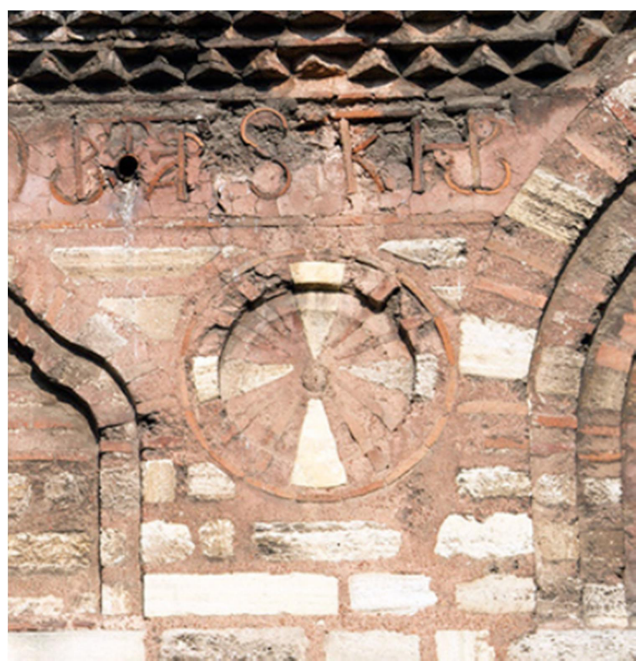

Figür 25: Pammakaristos Manastırı Güney Kilisesi rozet motifi detayı evresi olduğu düşünülen 327 yılını ve Osmanlı Dönemi'nde geçirdiği onarımları zikreden bir tamir kitabesinden hareketle yapıy: "eski temeller üzerine kurulmuşşimdiki şekli ile 19. yüzyıla ait bir yapıdır, gerek tarih gerek sanat değerlerinden tamamen mahrumdur" diye tanımlamaktadır62. E. Danık ise yüksek silindirik kasnak formunun 10. yüzyıl sonunda Yunanistan ve Balkanlar'da yaygın olduğunu belirterek, Anadolu'daki tek örnek olan Zeytinbağı/Tirilye'deki kilisenin kubbe kasnağı ile paralellik kurar. Araştırmacı, mimari verilere göre yapının Orta ve Geç Bizans Dönemi'ne tarihlendirilebileceğini öne sürer63. Sille Aya Elena Kilisesi ve Zeytinbağ1/Tirilye Kilisesi kasnağındaki rozet/güneş motiflerinin yapıların tarihlendirme sorunu nedeni ile tartışmalı olduğunu belirtmek gerekir. Her iki yapıdaki tuğla rozetler, Orta Bizans Dönemi'ne veya yapıların onarım kayıtlarına göre 19. yüzyıla tarihlendirilir64. Bu durumda 19. yüzyıldaki tarihlendirmeleri esas alırsak, rozet/güneş motifinin 19. yüzyıl Rum kiliselerinde yaşamaya devam ettiğini söylemek mümkün olacaktır65.

Makedonya'nın batısında Kastoria'da 10.-11. yüzyıla ait H. Anargyriou Kilisesi'nin batı ve doğu cephesinde üçer tane rozet bulunur ${ }^{66}$. Batı cephedeki rozetlerden ikisi dışında diğerleri tuğla çerçevelidir. Rozetlerin orta kısmında içbükey bir oyuk görülür67. Rozet motifinin yanı sıra testere dişi bezeme ve duvar örgüsünde tuğla XP monogramları, cephedeki diğer bezeme öğeleridir68. Kastoria Hagios Stephanos Kilisesi'nin doğu

Y. Ötüken'in çok sevdiği öğrencisi Sanat Tarihçisi E. Danık'ı saygıyla anıorum.

59 Mimiroğlu 2018, 353-354.

60 Sille Aya Elena Kilisesi kubbe kasnağında bulunan 12 ışınsal rozet/güneş motifi farklı ikonografik anlamlar içeriyor olmalıdır. Zikzak motifleri arasında tüm kubbe etrafında aralıklarla yerleştirilen motifler ilk olarak bezeme öğesi olarak her yönden algılanmak için yapılmış olduğunu düşündürür. Bununla birlikte evrenle ilişkili olarak mevsimleri 12 ayı simgeliyor olabilir. Hristiyan ikonografisi açısından ise 12 Havariyi simgelediği düşünülebilir.

${ }^{61}$ Kasnaktaki tuğla bezemeler için bk. Mimiroğlu 2018, 354; Mimiroğlu 2013, 174-219.

62 Sille Aya Elena Kilisesi S. Eyice'nin öğrencisi C. Sezer tarafından 1966 yılında lisans tezinde tanıtılmıştır. Bk. Eyice 1966, 158-159, dn. 46.

63 Danık 1997, 181, 190, fig. 3.

64 Tarihlendirmeler için bk. Danık 1997, 181; Eyice 1966, 158-159.

65 Rozet/güneş motifleri ve çarkıfelek motifinin 19. yüzyılda Osmanlı Dönemi'nde sivil mimarlık örneklerinde yaygın olduğu bilinmektedir. Ancak bu çalışma kapsamında değerlendirilmeye alınmamıştır.

66 Hoddinott 1963, 67, fig. 39.

67 Epstein 1980, 196, 16-18.

68 Hoddinott 1963, 67, fig. 39. 
cephesinde benzer şekilde iki rozet yer almaktadır. Buradaki büyük boyutlu ve simetrik rozetler "güneş ışığı" olarak tanımlanmıştır69 (fig. 27). Rozetlerin orta kısmında tuğladan XP monogramı bulunurken, aynı motif yapının duvar örgüsüne serpiştirilmiştir ${ }^{70}$. Kastoria'daki diğer yapıların cephesinde de İsa'nın monogramı olduğu düşünülen benzer motiflerle karşılaşılır'11. S. Y. Ötüken, Kastoria' da 11.-12. yüzyılda inşa edilen yerel üsluptaki kiliselerde süsleme motiflerinin duvar örgüsüne kaynaştırıldığını belirtir ${ }^{72}$. Z. Mercangöz ise Batı Anadolu'daki yapıların tuğla süslemelerinde rozet/güneş motifi ile birlikte monograma benzer motiflerin, Bafa Gölü'ndeki Kirselik Manastır Kilisesi'nin 13. yüzyıla tarihlenen ek yapısı doğu girişi yanında; ayrıca Kemal Paşa'daki Laskarisler Sarayı cephesinde olduğu bilgisini verir ${ }^{73}$. Yunan alfabesinde İsa'yı simgeleyen XP harflerinin iç içe geçmesiyle oluşan monogram, rozetlerin sembolik anlamına ilişkin görüşümüzü kuvvetlendirir. Ayrıca Batı Makedonya, Verria Hg. Paraskevi Kilisesi'nin kapısı üzerinde haç ve rozet/güneş motifi yan yana görülür ${ }^{74}$. Makedonya'da Ohri kentinde bulunan Aziz Klement ve Panteleimon Kilisesi'nin orijinaline uygun olarak inşa edilen yapısında iki tane rozet/güneş motifi dikkati çeker ${ }^{75}$.

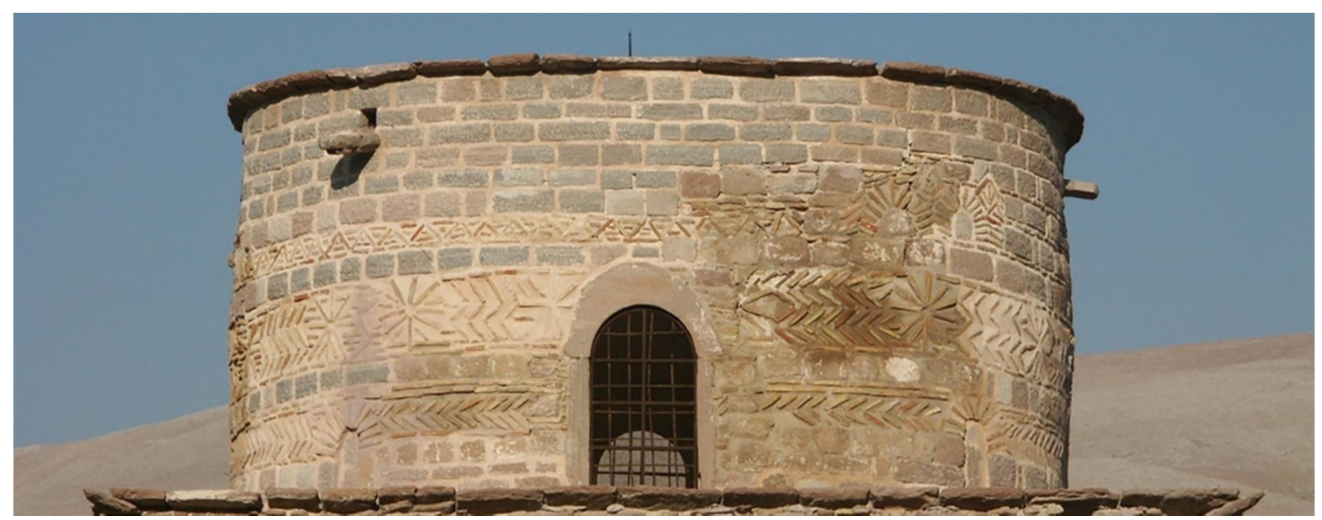

Figür 26: Konya, Sille Aya Elena Kilisesi kubbe kasnağı

4. yüzyıla tarihlendirilen Selanik Galerius Sarayı'ndaki oktagon yapısının kuzey nişinde erken tarihli bir rozet bulunmaktadır ${ }^{76}$ (fig. 28). Buradaki motifin merkezinde, diğer örneklerden farklı olarak eşit kollu bir haç vardır. Motifin iki yanında ise tuğladan, olasılıkla palmiye dalı olduğu düşünülen, bitkisel bir bezeme yer alır. Kuzey nişteki rozet ve palmiye dalları yapıldığı dönemde orijinalde sıva ve duvar kaplamalarının altında bulunur. Bu nedenle tuğla süslemeler sarayın inşası ile aynı evreye, yani 4. yüzyılın ilk yarısına tarihlendirilir ${ }^{77}$. Dolayısıyla Selanik'teki yapıların cephesindeki tuğla rozet/güneş motiflerinin köken olarak Geç Antik Dönem’e kadar uzandığı söylenebilir.

Selanik'te geç 13.-erken 14. yüzyıla tarihlendirilen Peribleptos Meryem Manastırı, Aziz Panteleimon Kilisesi'nin (Osmanlı Dönemi Ishakiye Camii) doğu cephesinde, ortasında

\footnotetext{
69 Epstein 1980, 194, dn. 14.

70 Hoddinott 1963, 67, fig. 38; Epstein 1980, 194, dn. 14.

71 11. yüzyıl Kumpelidiki Meryem Kilisesi tuğla süslemeleri için bk. Mercangöz 1990, lev. 26, fig. 12.

72 Ötüken 1978, 218.

73 İzmir Çakaloğlu Hanı güney cephesinde monogram ile güneş motifinin kaynaştırılmış olduğu belirtilir. Ancak yayında hanın tarihi 18. yüzyıl olarak geçmektedir. Bk. Mercangöz 1995, 490, dn. 29.

74 Hoddinott 1963, 67, fig. 38-39. Güneş motifi ayrıca Makedonya Hanedanlığının sembolü olarak siyasi bir anlam taşır. Makedonya İmparatoru Philippos'un küllerinin saklandığı sandık üzerinde güneş motifi bulunur. Bk. Kırıkçı 2004, fig. 8.

75 "Saint Panteleimon church," 2021.

76 Hoddinott 1963, 123-124, fig. 24e; Vicker 1973, 114, fig. 9.

77 Buradaki motif haçı andırır ancak kanımızca tartışılmalıdır. Motifin tarihlendirilmesi ve detaylı tartışma için bk. Vickers 1973, 114-116, fig. 9.
} 
beyaz renkli taş olan bir rozet bulunur ${ }^{78}$. Selanik'te benzer motifin görüldüğü bir diğer yapı, orijinalinde manastırın katholikonu olan, 1310-1314 arasına tarihlendirilen Hagios Apostoloi Kilisesi'dir (Kutsal Havariler Kilisesi, Osmanlı Dönemi Soğuksu Camii). Kilisenin ek yapılarında doğu cephedeki kör kemerlerin köşesinde 4 tane simetrik tuğla rozet/güneş motifi görülürr9. Rozetlerin ortasına, olasılıkla diğer örneklerdeki gibi beyaz renkte bir taş yerleştirilmiştir80. C. Texier ve R. P. Pullan'ın 1864 tarihli yayınındaki doğu cepheyi gösteren çizimde, tuğla rozetlerin çerçeve ile sınırlandırıldığı görülür81 (fig. 29). 12. yüzyıla ait Vatikan Kodeks Vat. Gr 1162 numaralı yazmada, İstanbul'daki Kutsal Havariler Kilisesi'ni betimleyen bir minyatürde, yapının cephesinde iki rozet motifi olması ilginç bir ayrıntıdır ${ }^{82}$.

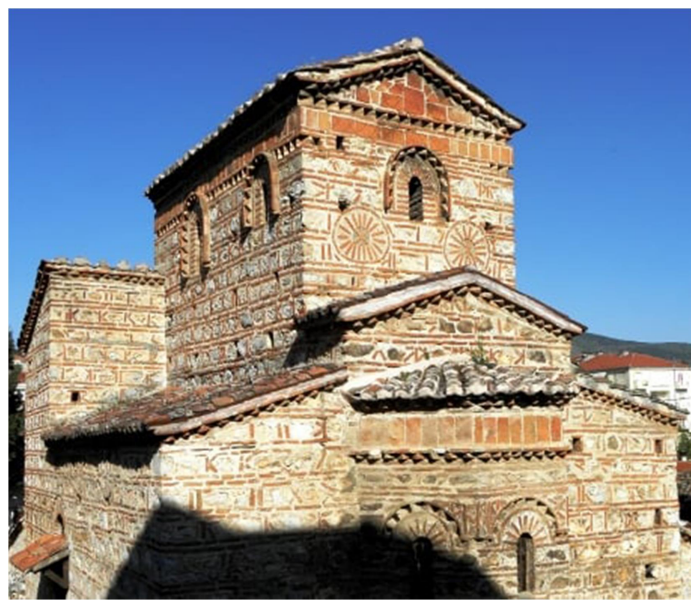

Figür 27: Batı Makedonya Kastoria Hagios Stephanos Kilisesi doğu cephesi

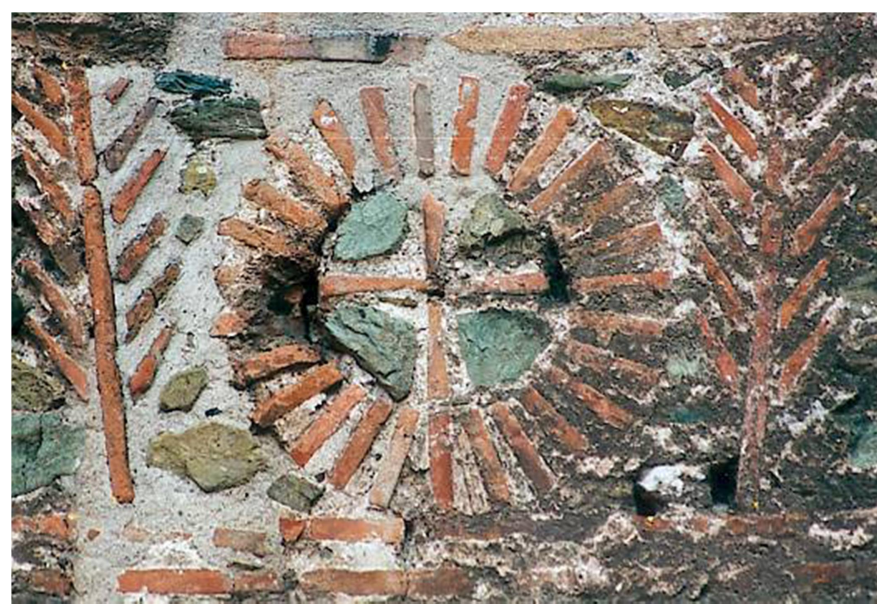

Figür 28: Galerius Sarayı oktagon yapısı kuzey niş duvarı güneş motifi ve palmiye dalları

Yunanistan' da Mistra Panagia Pantanassa Bazilikası' na (1428) bitişik olan dört katlı kule şeklindeki yapının, katları ayıran frizlerin hizasında çok sayıda dairesel rozet bulunur. 1887 tarihli çizimde bu rozetlerden bazılarının ışınsal bezemeli olduğu anlaşılır. Aynı yayında Mistra Kalesi'nde bulunan benzer yuvarlaklar, rozet veya Gotik pencere açılı̆ğ1 olmalıdır ${ }^{83}$. H. Buchwald, Bizans'ın son devrinde İstanbul'da dışında Mistra, Bulgaristan ve Güney Macaristan'da Laskarisler Dönemi mimarisi etkisinin görülmesini, 13. yüzyıldan itibaren Batı Anadolu'dan buralara göçe bağlar ${ }^{84}$. Mimaride görülen bu etkileşim, tuğladan yapılmış ışınsal rozet motiflerinin yaygınlığını açıklar.

S. Y. Ötüken, Sakız Adası'ndaki kiliselerde yerel özelliklerin yanı sıra başkent örnekleri ile paralel öğeler bulunduğunu belirtir85. Ada' daki 12.-13. yüzyıllara tarihlendirilen Panagia Sikelia Manastır Kilisesi orijinalinde kadınlar manastırı olarak bilinir ${ }^{86}$. Bu kilisenin güney haç kolundaki kör kemer alınlığında, ortasında haç olan tuğladan bir madalyon bulunmaktadır 87 . Haç motifi keramoplastik süs çömleklerinden yapılmıştır. Madalyonun çerçevesi tuğladan testere dişi şeklinde bezemelidir. Madalyonun etrafındaki tuğla zikzak motifleri ise haçın etrafına yaydığı ışığın stilize hali olmalıdır.

\footnotetext{
${ }^{78}$ Fotoğraf için bk. "Grande Flânerie," 2020. Kilise için bk. Kourkoutidou-Nikolaidou ve Tourta 1997, 45-47.

${ }^{79}$ H. Apostoloi'daki rozet motifleri için bk. "Church of the Holy Apostles," 2020, Ekim 25.

80 Fotoğraf için bk. "Grande Flânerie," 2020.

81 Texier ve Pullan 1864, 148.

82 Minyatür için bk. "Church of the Holy Apostles," 2020, Kasım 24.

83 Schweiger-Lerchenfeld 1887, lev. 74.

${ }^{84}$ Buchwald 1984, 233.

85 Ötüken 1978, 222, 228, fig. 27.

86 "Sak1z Adası Manastırları," 2021.

87 Ötüken 1978, 232, fig. 35.
} 
Bulgaristan'da Misivri Sv. Ivan Aleiturgetos Kilisesi mimari özelliklerine göre 13.-14. yüzyıla tarihlendirilir. Süsleme öğeleri başkentle karşılaştırılan kilisenin güney cephesindeki kör kemer alınlıklarında tuğla rozetler bulunur ${ }^{88}$. Rozetlerin merkezi diğer örneklerde olduğu gibi yuvarlak değil, dört yönde yonca şeklinde genişletilmiştir. Bu kısımda, olasılıkla madenden kakma bir haçın yerleştirilmesi için yapılmış delikler bulunur. S. Y. Ötüken, kilisenin cephe süslemelerinin başkent mimarisini yakından tanıyan veya orada yetişmiş ustalar tarafından yapılmış olabileceğini öne sürer ${ }^{89}$.

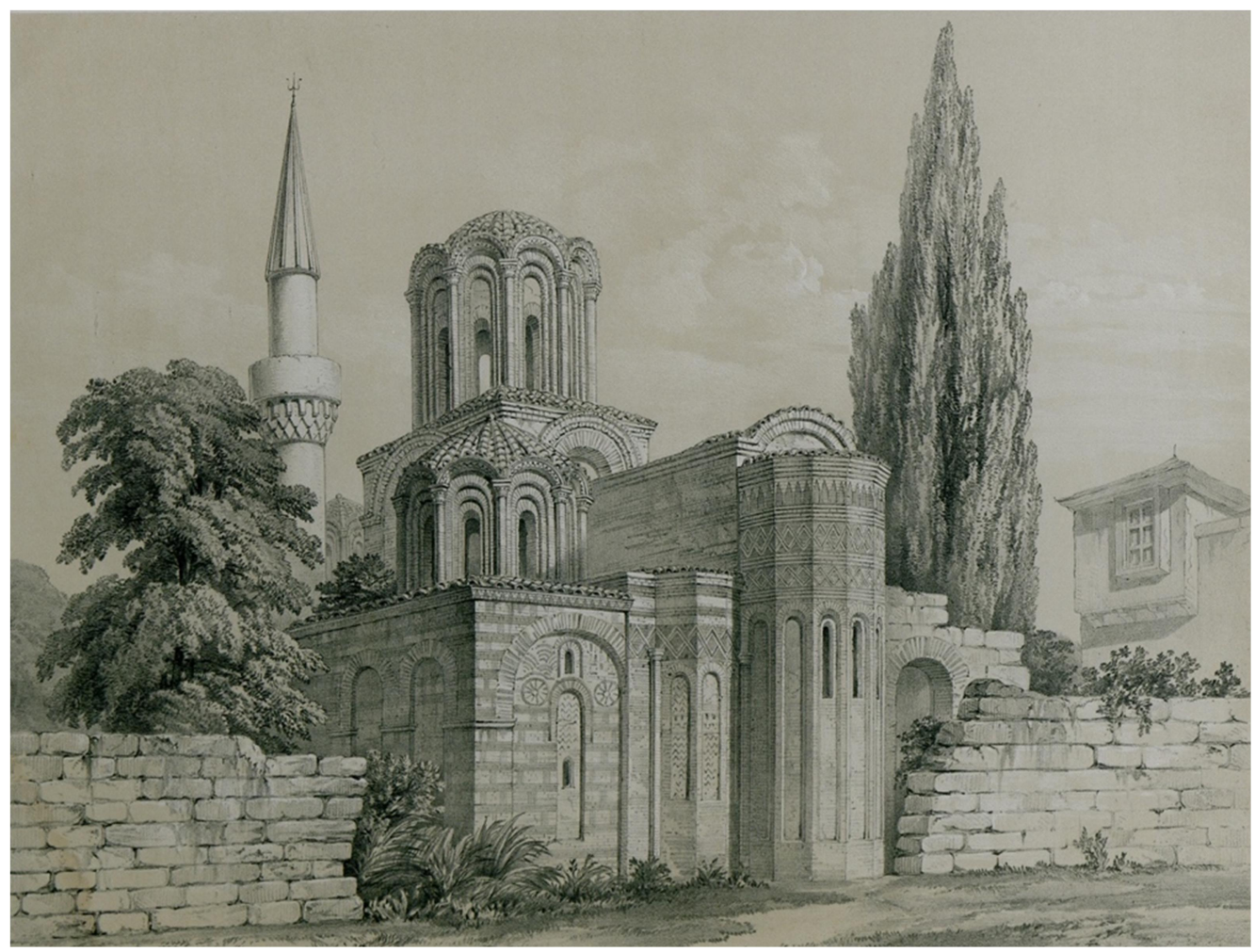

Figür 29: Selanik Hagios Apostoloi Kutsal Havariler Kilisesi (Osmanlı Dönemi Soğuksu Camii)

Bizans mimarisinde ışınsal tuğla rozetler kiliseler dışında savunma yapılarında karşımıza çıkar. Bununla birlikte, ışınsal rozetlerin savunma yapılarındaki erken örnekleriyle Geç Antik Dönem'de İtalya ve Kuzey Avrupa'da surlarda karşılaşılır ${ }^{90}$. Ankara Kalesi' nde, 9. yüzyılın ortalarına tarihlendirilen iç surun almaşık teknikteki duvar örgüsünde, tuğla çerçeveli ışınsal bir rozet bulunur. Rozetin ortasındaki dairesel oyuk diğer örneklere göre küçüktür ${ }^{91}$. Gebze, Eskihisar Kalesi'nde, kuzeybatıdaki dört katlı kule benzeri bir yapının batı cephesinde, düzensiz radyal tuğlalarla oluşturulmuş benzer bir motif yer almaktadır. Yapının ikinci kat pencerelerinin güneyinde ise tuğladan bir gamalı haç motifi bulunur ${ }^{92}$.

Bizans ve Erken Osmanlı arasındaki kültürel etkileşime bağlı olarak, 14-15. yüzyıla ait Osmanlı yapılarında tuğla rozetlerin devam ettiği görülür. Bununla birlikte günümüze gelen az sayıdaki örnekten, motifin yaygınlığı konusunda kesin bir şey belirtmek güçtür. Z. Mercangöz, Bafa Gölü çevresindeki çalışmaları sırasında bölgedeki Bizans yapıları dışında, Erken Osmanlı/Beylikler Dönemi yapılarında benzer tuğla rozetler olduğunu belirtir93.

88 Ötüken 1978, 224, 232, fig. 35.

89 Ötüken 1978, 226.

90 Dey 2010, 3-37.

91 Serin 2014, 75, fig. 10.

92 Bahar 2013, 28, fig. 61, 165, fig. 133, a-c. 28.

93 Demiriz 1979, 425, fig. 121, 304, fig. 201, 203, 314, fig. 215, 448, fig. 434, 593, fig. 640; Mercangöz 1990, 135 , dn. 34. 
Bizans mimarisi üzerine değerli çalışmalar yürüten R. Ousterhout, Konstantinopolis (İstanbul) ve Bithinya Bölgesi'nde Geç Paleologoslar Dönemi mimarisindeki değişimleri ele aldığı ilgili yayınında, tuğla rozet motiflerinin Geç Bizans ve Erken Osmanlı mimarisindeki örneklerinden söz eder ${ }^{94}$. Y. Demiriz, Erken Osmanlı mimarisindeki tuğla rozetleri şöyle tanımlar: "...oldukça yaygın bir şekilde cephenin muhtelif yerlerinde tuğlaların radyal yerleştirilmesi ile elde edilen rozetlerdir." Bunun yanı sıra motifin Bursa'da Orhan Camii, Yenişehir Seyyid Mehmet Dede Zaviyesi, İznik Nilüfer Hatun İmareti, Mustafa Kemal Paşa' da Lala Şahin Paşa Türbesi, Bursa'da Timurtaş Camii gibi 14. yüzyıl yapılarında, belli bir düzene uymaksızın cepheye yerleştirildiğinden bahseder. Araştırmac1, tuğla rozetlerin kökeni konusunda görüşler öne sürer: “...Bunlara bazı araştırıcılar tarafindan güneş kursu denilmekte ve bazı sembolik manalar atfedilmektedir. Bizce saf dekoratif olan bu rozetlerin çok erken bir örneğini, Talas'da Balaci Hatun Türbesinin cephesinde tespit edebiliyoruz. Böylece, pek çokları tarafindan Bizans tarzı olarak kabul edilen tuğla cephe süslemesinin bir motifini daha Türk sanatının beşiği olan bölgelerde bulabildiğimize işaret etmek isteriz"95. 14. yüzyıl Erken Osmanlı mimarisinde yaygın olan tuğla rozetler elbette Bizans-Erken Osmanlı etkileşimi bağlamında değerlendirmeyi zorunlu kılar.

Tuğla rozetler üzerine spesifik bir çalışmaya sahip olan S. Kalfazade, Bizans ve Erken Osmanlı mimarisindeki rozetleri yapı ve süsleme ilişkisi çerçevesinde inceler ${ }^{96}$. Araştırmacı bu bağlamda rozetleri şöyle tanımlar: "Osmanl rozetleri, genellikle her biri tek bir motiftir, herhangi bir kompozisyonun parçası değildir. Bizans rozetleri süslemeyle iç içe olduğu halde, Osmanl rozetleri mümkün olduğunca süslemeden soyutlanmış, çılak duvar yüzeyin üzerine yerleştirilmişlerdir. Bu nedenle Bizans örneklerinde görüldüğ̈̈ anlamda duvarla bütünleşme yoktur, rozetler duvarla tam kaynaşmamış "ekleme" birer motiftir". Bununla birlikte Y. Demiriz ile aynı görüşte olup, tuğla rozetlerin Bizans'a özgü olmadığını, 10.-12. yüzyıla tarihlendirilen Tim'deki Arap Ata Türbesi ve Talas'daki Balacı Hatun Türbesi'nde erken örnekleri bulunduğunu belirtir ${ }^{97}$. 14.-15. yüzyıla tarihlendirilen Erken Osmanlı Dönemi yapılarındaki rozetlerle ilgili şu saptamalarda bulunur: “Bu örnekler, tuğla rozetlerin Osmanlı mimarisi içinde belli bir yapı türüne bağlanmaksızın değişik fonksiyonlar içeren yapılarda uygulandığını gösterirken, aynı zamanda geniş bir kullanıma işaret etmektedir. Rozetlerin, bazı araştırmacıların, "güneş diski" olarak yorumlamalarmın aksine yalnızca dekoratif amaçh kullanılmış oldukların sanıyoruz. Bizce bunun en büyük göstergesi her yapıda farkh görünümde olmalarl, bazen de süsleme açısından yapının genel karakterine uygun şekilde bezenmeleridir. Bu durum, rozetlerin sembolik anlamlar içermekten çok, yapının genel süsleme programı içinde ele alını, daha çok dış cephe süsleme unsuru olarak kullanıldıklarını düşündürtmektedir"98. Araştırmacı aynı zamanda Bizans ve Osmanlı rozetlerini karşılaştırır: "Osmanlı rozetleri, hemen her yapıda farklılaşan görünümlerine karşın, Bizans rozetleri gibi zengin bir tuğla işçiliği göstermezler...Rozetlerin orta kısımlarn -istisna oluşturan birkaç örnek dişında- boş bırakılmış, herhangi bir dekoratif unsurla dolgulanmamışıtır. Rozetlerde, Bizans geleneğinin devamcısı olarak süsleme için özel hazırlanmış tuğlaların kullanılmış olduğu görülmektedir" ${ }^{\prime 9}$. Elbette güneş motifi pek çok uygarlıkta olduğu gibi İslam öncesi ve sonrası Türk sanatından bilinen bir semboldür ${ }^{100}$. Bu bağlamda Bursa Orhan Gazi ve İznik Nilüfer Hatun İmareti'nde rozetlerde sırlı tuğla, orta kısımda çini ve yıldız motifi kullanımı, Bizans'taki haç motifinin İslam sanatındaki yorumu olarak algılanabilir ${ }^{101}$.

\footnotetext{
94 Ousterhout 1991, 86-90, fig. 22, 29, 31.

${ }_{95}$ Demiriz 1979, 15.

96 Kalfazade 1987, 12-17.

${ }_{97}$ Kalfazede 1987, 12.

98 Kalfazade 1987, 12-13.

99 Kalfazade 1987, 15.

100 Makalede çok geniş bir literatürü kapsayan İslam öncesi ve sonrası dönemlerde Türklerde güneş sembolünden bahsedilmiştir. Ancak detaylı bir çalışma için bk. Kırıkçı 2004.

101 Kalfazade 1987, 15, 17.
} 
D. Kuban ise İznik'te Nilüfer Hatun İmaretini tasvir ederken, bezemelerinin yerli Bizanslı ustalarca yapılmış olduğunu belirtir102. Bununla birlikte Bursa'da Yıldırım Darüşşifası'nın giriş cephesindeki tuğla çerçeveli 1şınsal bezeme, Bizans örnekleri ile oldukça benzerdir ${ }^{103}$. Bursa Orhan Camii (1339) son cemaat yerindeki tuğla rozet veya güneş kursu, muhtemelen Bizanslı ustaların 14. yüzyıl öncesinde bölgenin mimari süsleme geleneğinde var olan motifleri tercih ettiğini gösterir104. Bizans yapılarının fetihten sonra zaman içinde tahrip olması nedeni ile doğrudan ilişkilendirememekle birlikte, motifin 14.-15. yüzyıl Beylikler mimarisinde devam ediyor olması, aynı yüzyıllarda Geç Bizans kiliselerinin cephesinde halâ yaşadığı ve ustalarca bilindiği savını kuvvetlendirmektedir. İzmir'de 19. yüzyıla ait Çakaloğlu Hanı dışında, Sille ve Tirilye'deki kiliselerde tuğla rozet/güneş motifinin Hristiyan ustalarca yapılmış olabileceği tahmin edilmektedir ${ }^{105}$.

\section{Sembolizm}

S. Y. Ötüken, "İstanbul'da Son Devir Bizans Mimarisinde Cephe Süslemeleri" ile ilgili makalesinde, bir merkezden çıkan tuğladan yapılmış ışınsal bezemeleri "güneş motifi" olarak tanımlar ${ }^{106}$. Kuzey ek yapının cephesinde yer alan benzer motifleri ise "rozet" olarak adlandırır ${ }^{107}$. Yayınlarda motifin kökeni ve terminolojisi konusunda benzer şekilde ortak bir görüş olmadığı dikkati çeker. Bu bölümde rozet/güneş motifinin kökeni ve sembolik anlamları tartışılacaktır. Bu bağlamda öncelikle 'tuğla rozetlerin uygulandığ tesadüf mü yoksa kutsal alanla bir ilişkilisi var mı?' sorusunu cevaplamaya çalışacağız. İkinci olarak ise 'tuğla rozet/güneş motifleri bir bezeme unsuru mudur yoksa Bizans/Doğu Roma kültüründe, bugün bilmediğimiz sembolik bir anlamı var mıdır?' sorusunu tartışacağız.

Kuzey ek yapının K5 ve K6 mekânlarının Aziz Nikolaos'un yağ kültüyle ilişkili törenlerde, yağın kutsandığ 1 myrophylion ve myrophylakion olduğu öne sürülür108. Kiliseye kuzeydoğudan bitişik olan C2 mekânının ise işlevi tartışmalı olmakla birlikte, mezar yapısı olabileceği belirtilir109. Dolayisiyla cephesinde tuğla rozetlerin bulunduğu K5 ve C2 mekânları, manastırın kutsal alanlarıdır. Bu yapıların cephesinde, duvarların üst seviyesine yerleştirilen rozetler, aynı zamanda mekânları manastır kompleksi içinde vurgulamıştır. Rozetlerin mekânlardaki dini ritüelle doğrudan ilişkili bir anlamı olup olmadığ1 bilinmemekle birlikte, mekânların önemli bir işlevi olduğuna dikkati çektiği açıktır. Geç Bizans Dönemi kiliselerinde rozetlerin özellikle tuğla süslemelerin yoğun olduğu doğu cephede olması beklenir. İncelediğimiz örneklerde ise rozetler belli başlı yapılarda genellikle doğu cephede olmakla birlikte, kuzey-güney ve batı cephede de uygulanmıştır. S. Y. Ötüken, kuzey ek yapının cephesinin bezemeli oluşunu, antik Myra kentine yönelik olması ile açıklar110. Bu sayede duvarların üst seviyesindeki rozet bezemeler, manastırın yüksek çevre duvarları dışından kolaylıkla görülür.

Rozetler gibi dairesel formlu bezemelerin, yapının cephesinde üst seviyede uygulanmasının nedenlerinden biri, kanımızca motiflerin kendi arasındaki hiyerarşiyle ilgili olmalıdır. Bu motifler kozmoloji ile bağlantılı görüldüğünden, Selçuklu yapılarının cephesindeki güneş, ay ve kabaralar gibi üst seviyede yapılmışlardır. Sivas Keykavus

\footnotetext{
102 Kuban 2016, 86.

103 Mercangöz 1995, 492, fig. 1.

104 Bursa'da Erken Osmanlı Dönemi yapıları için bk. Ayverdi 1966.

105 Mercangöz 1995, 490, dn. 29.

106 Ötüken 1978, 213-233.

107 Ötüken et al. 1999/2000, 221-242.

108 Ötüken 2005, 265.

109 Ötüken 1997b, 474; Ötüken 2002, 591.

110 Ötüken et al. 1999/2000, 227.
} 
Darüşşifası (1217) kemer köşesindeki güneş ve ay kabartmaları, Niğde Alâeddin Cami (1223) taç kapısındaki güneş ve ay sembolleri bu görüşü somutlaştıran örneklerdir111. Bazı motiflerin, sembolik anlamlarına bağlı olarak uygulandığı yer konusunda, yapı ustalarının ortak bir dile sahip olduğu söylenebilir. J. Trkulja, görüşümüzü destekler nitelikte apsis, pencere, kemer köşesi, kalkan duvarının üst seviyesi gibi mimarinin önemli kilit noktalarına yerleştirilen anikonik disklerin (rozet/güneş motifi) sembolik bir anlamı olduğunu belirtir. Bu şekilde vurgulu bir düzenlemenin, motifin göstergebilimsel önemine ve anlamina işaret ettiğini ileri sürer112. Bu bağlamda 1şınsal tuğla rozetleri Y. Demiriz ve S. Kalfazade'nin görüşlerinin aksine, yalnızca cephedeki bir süs unsuru olarak değerlendirmenin doğru olmayacağı kanısındayız.

J. Trkulja, Bizans mimarisinde kullanılan yuvarlak diskleri üç kategoriye ayırır. Bunlardan konumuzla ilişkili olarak düz çizgiye sahip olanları "güneş 1şığı", dönen çizgiler halinde olanları "dönen yuvarlak diskler" yani "çarkıfelek" motifi olarak tanımlar113. Dönen yuvarlak diskler/çarkıfelek/rüzgar gülleri Suriye' de Erken Hristiyanlık Dönemi yapılarında güneş diski, yıldız, haç gibi sembolik motiflerle birlikte taşa uygulanmıştır. Suriye'de Surqanya'da, dönen disklerin etrafındaki şeritte, Aziz Nikolaos Kilisesi'nde C2 yapısındaki örnekte olduğu gibi zikzak motifi dikkati çeker114. I. Peña, "rüzgar gülü" olarak adlandırdığı 24 yapraklı motifi, Eski ve Yeni Ahit'ten 12'şer peygamberle ilişkilendirir ve bu motifin Doğu Hristiyanlığı için "Kiliseyi" simgelediğini belirtiri115. E. Schwartz ise dönen diskleri güneş ve 1şıkla ilişkilendirmenin dışında, evrenin kendisi ile bağlantı kurmuştur ${ }^{116}$. Bizans sanatından alışkın olduğumuz dönen yuvarlak diskler/çarkıfelek/rüzgar gülü motifi, Ermeni sanatında da evreni ve sonsuz dönüşü sembolize eder ${ }^{117}$. Dönen diskler aynı zamanda logosun sembolü olarak tanımlanır118. İncelediğimiz örneklerde karşılaşılan dönen disk/çarkıfelek/rüzgar gülü olarak adlandırılan motifin, ışık ve evrenle alakalı, sonsuzluğa ilişkin ilahi anlamları benzerlik gösterir. Bu motifin güneş diski ve sembolik anlamı olan diğer diskler kategorisinde, izleyiciler tarafından bilinen ortak bir dilin işaretleri olduğu sanılmaktadır.

Bizans mimarisinde yapıların cephesini süsleyen rozetlere farklı sembolik anlamlar yüklendiği görülür. J. Trkulja, bu motiflerin Hristiyanlıkla ikonografik bağlantısını kurarak, kiliselerin dekorasyonunda kullanılan disklerin (rozet/güneş motifi) ilahi bir sembol olduğunu iddia eder119. Kypseli'deki 13. yüzyıl Aziz Demetrios Kilisesi'nin apsis cephesindeki tuğla rozetleri, makalemizle benzer bir yaklaşımla ele alır. Araştırmacı, mimari formlar ile bezeme öğeleri arasındaki ilişkiyi açıklar. Buna göre bilgelik makamı olarak Meryem'e ayrılmış olan apsis, şekli dolayısıyla İsa'nın doğduğu mağaraya veya Meryem'in rahmine benzetilir. Bu nedenle merkezinde güneş patlaması olan disklerin, Bakire Meryem'in "İlahi Işı̆̆ı" yani İsa' yı dünyaya getirmesi olarak algılanabileceğini belirtir ${ }^{120}$. Bu görüşü destelemek için benzer disklerin Peć'teki Hodegetria Meryem Kilisesi'ndeki freskoda, Meryem'i çevreleyen apsis kemerini anımsatan bir düzenlemenin iki yanında

\footnotetext{
111 Kırıkçı 2004, fig. 45-46, 47.

112 Trkulja 2011, 226.

113 Üçüncü tip ise farklı boyutlarda iki veya üç eş merkezli dairenin üst üste bindirildiği disklerdir. Bk. Trkulja 2011, 226, dn. 39.

114 Peña 1997, 175.

115 Peña 1997, 174.

116 Schwartz 1977, 24-29.

$117 \mathrm{Bu}$ motif Ermeni mezar taşlarında haçla birlikte kullanılmıştır. Ayrıca dönen disk motifleri Ani'deki Tigran Honnest Kilisesi'nde olduğu gibi kiliselerin kubbesinde görülür. Bk. Trkulja 2011, 226, dn. 44.

118 Radojčić 1971, 16.

119 Trkulja 2011, 226

120 Trkulja 2011, 226.
} 
görüldüğünden bahseder ${ }^{121}$. Ayrica benzer motiflerin Sinai'deki Aziz Katherina Manastırı'nda 1136-1155 tarihli Nazianzoslu Gregor'un Homiliesi'ndeki (fol. 4. v.) minyatürde, Meryem'in yaşamını anlatan 1125 tarihli Kokkinobaphoslu Yakup'un Homiliesi' ndeki (Paris, Bibliothèque Nationale Ms. Gr. 1208) "Göğe Yükselişs" sahnesinde yer aldığını belirtir ${ }^{122}$. Hâlbuki incelediğimiz örneklerde rozet motifleri yalnızca apsis cephesinde değil, yapının farklı yerlerinde de uygulanmıştır. Bu nedenle araştırmacının görüşü yalnızca tek bir yapı bazında apsis cephe düzenlemesi üzerine tartışma yaratır.

J. Trkulja, Geç Bizans Dönemi'nde Ortodoks teolojisine hâkim olan Hesychast (İsihazm: dinginlik, dinlenme, sessizlik, münzevi) teolojisinin dönemin sanatını etkilediği görüşündedir. Bu öğreti özellikle 14. yüzyılda etkili bir ilahiyatçı olan Gregory Palamas'ın fikirlerindeki "ilahi 1şık" veya "yaratılmamış 1şık" kavramına karşılık gelmektedir ${ }^{123}$. Eski ve Yeni Ahit'te Tanrı'nın ilahi varlığı bir 1şıkla tezahür eder ${ }^{124}$. Araştırmacıya göre, bu düşünceler iç mimaride boya, dişta ise tuğla ve taştan yapılmış, ışığı sembolize eden parlak disk ve frizler aracılığıyla uygulanmıştır. Daire, şekli itibariyle mükemmelliği ve sonsuzluğu yani ilahi olanı çağrıştırır. Bununla birlikte tuğladan yapılmış rozetler, 14. yüzyılın ortalarında azalarak yerini dairesel pencerelere bırakmıştır ${ }^{125}$. Elbette bu görüş dönemin teolojik yaklaşımı ile anlamlı bir önerme olarak kabul edilebilir, ancak 4. yüzyıldan itibaren örneklerini bulduğumuz tuğla rozetleri açıklamak için yetersiz kalır. Burada sorulması gereken, rozetler gerçekten aynı anlamda 1şık/güneşi simgeliyorsa, kiliselerin cephesinde, duvar resmi veya el yazması örneklerinde neden birden fazla olduğudur. Bu sorunun sadece cephe düzeninde simetriyi sağlamak dışında cevabını bulamadığımızı belirtmek isterim.

Aziz Nikolaos Kilisesi'ndeki rozetlerin literatürde "güneş motifi" olarak adlandırılması dışında, cephe düzenlemesindeki diğer öğelerle birlikte düşünüldüğünde 1şıkla bağlantı kurmamızı sağlayacak başka bir kanıt arayışına girilmiştir. K5 mekânının cephesindeki rozet/güneş motifinin altında, tuğladan yapılmış bir zikzak/testere dişi frizi yer alır ${ }^{126}$. Bu motifin ışıkla ilişkisini kurmamızı sağlayan araştırmacıların görüşleri aşağıda tartışılmıştır.

R. L. Moss, chevron/zikzak motifinin Romanesk mimarideki uygulamaların incelerken; 6.-12. yüzyıllarda Yakın Doğu ve Avrupa minyatür sanatında motifin özellikle mimari tasvirlerin imitasyonunda üç boyutlu mimariyi vurgulamak için kullanımına işaret eder127. S. Curcíć ise makalemizle paralel olarak motifin sembolik anlamı konusunda önemli değerlendirmelerde bulunmuştur. Araştırmacı bu motifler için "...belirli mimari formlarm sembolik anlamlarına ilişkin araştırmamız göz önüne alındığında, bu tür frizler, İlahi Işık kavramıyla ilgili sembolik bir anlamı olan motifler listesine eklenmelidir" demektedir ${ }^{128}$. Zikzak/testere dişi motifinin taş, tuğla, fresko, minyatür gibi pek çok farklı tür ve teknikte uygulanmış örneklerinin "ilahi 1şığı" sembolize ettiği öne sürülür129. Bizanslı sanatkâr ve yapı ustalarının, "ilahi 1şık" kavramını fiziksel olarak ifade etmek için ortak sembolik bir dil kullanımı tartışılır130. Yukarıda bahsettiğimiz gibi benzer düşüncede olan J. Trkulja, soyut bir kavram

121 Trkulja 2011, 245, fig. 13.

122 Trkulja 2011, 238, fig. 1, 239, fig. 2.

123 Trkulja 2011, 224; Tomoioagă 2015, 142-153.

124 Ćurčić 2012, 307-308.

125 Trkulja 2011, 224, 227; Trkulja 2012, 227.

$126 \mathrm{Bu}$ bezeme öğesinin Romanesk dönemde kullanımı ve sembolik anlamı üzerine kapsamlı bir çalışmanın yanı sıra, motifin farklı kültürlerde uygulamaları üzerine yapılan anolojik çalışmada, köken ve kronolojisi üzerine tartışılmıştır. Bk. Moss 2000; Kolay ve Erdoğan 2019, 241-256.

127 Moss 2000, 164.

128 Ćurčić 2012, 327.

129 Ćurčić 2012, 307-337.

130 Ćurčić 2012, 313. 
olan ilahi ışığın rozet veya frizler aracılığıyla ifade edildiği görüşündediri131. 11.-12. yüzyıla tarihlenen rozet motifleri ile birlikte tuğla ya da boya ile yapılmış zikzak motifleri, 1şığın etrafına yaydığ "ilahi enerji" ile ilgili olmalıdır. Bu olgu daha sonra 13. yüzyılda Gregory Palamas tarafından "Tanrı'nın yaydığı enerji" olarak tanımlanacaktır ${ }^{132}$. Tuğla ile sağlanan ilahi ışığın üç boyutluluk olgusu, duvar resmi veya mozaikte katlanmış bant öğeleri ve gölgeyle verilmeye çalışılmıştır ${ }^{133}$. Bizanslı yapı ustalarının ya da banilerin dini öğretilerden hareketle, sembolik öğeleri bilinçli bir şekilde kullanmaya çalıştığını gösteren ve araştırmacıların görüşlerini de bu bağlamda destekleyen iyi bir örnek, Sakız Adası'nda bulunur ${ }^{134}$. Panagia Sikelia Manastır Kilisesi'nin güney cephesinde, etrafına ışınlar saçan madalyon içindeki haç motifi, Ioannes Hrisostomos'un "haç güneşten daha parlak parlıyor" sözlerinin somutlaştırılmış hali olmalıdır ${ }^{135}$. Suriye'de Erken Hristiyanlık Dönemi'ne ait yapılarda taşa oyulmuş olan güneş diski veya rüzgar gülü motifleri bir zikzak şeridi ile çevrelenmiştir ${ }^{136}$. Aziz Nikolaos Kilisesi'nin C2 yapısı cephesinde yer alan rozetin etrafındaki şeritte zikzak motifi olması tesadüf değildir. Benzer şekilde günümüze gelmemekle birlikte K5 mekânındaki rozetin etrafında da zikzak motifi olabileceği tahmin edilmektedir. Buradaki rozetin altında yer alan testere dişi frizi, yukarıda söz ettiğimiz ilahi ışık kavramı ile ilişkili olarak üç boyutluluk algısı oluşturur. Ayrıca tuğla testere dişi/zikzak frizinin yapının başka hiçbir yerinde kullanılmamış olması, 1şınsal rozetlerin ışıkla bağlantılı sembolik bir anlamı olduğunun kanitıdır.

Tuğladan yapılmış zikzak/testere dişi/chevron motiflerinin tuğla rozetlerle birlikte kullanıldığ 1 görsel olarak en etkili örneklerden biri, Konya Sille Hagios Mikhael (Aya Elena) Kilisesi'nin silindirik kubbe kasnağıdır. Bu yapıda dikey ve çoklu sıralar halindeki zikzak motifleri arasında tuğla rozetler yerleştirilmiştir. Buradaki zikzaklar doğrudan rozet/güneş motifinin etrafına yaydığ1 1 şı veya enerjiyi sembolize ederler ${ }^{137}$. Benzer şekildeki tuğladan dikey zikzak motifleri Konstantin Lips Manastırı Güney Kilisesi (1281-1304, Fenari İsa Camii) ile geç 13.-erken 14. yüzyılda Peribleptos Meryem Manastırı Kilisesi doğu cephesinde görülür138. Testere dişi motifleri 10.-11. yüzyıl Kastoria' daki Hagios Stephanos Kilisesi ve H. Anargyriou Kilisesi'nde tuğla rozetlerle birlikte doğu cephede kullanılmıştır ${ }^{139}$. S. Y. Ötüken, başkent Konstantinopolis (İstanbul) ile Yunanistan'daki yapılarda testere dişi frizlerinin kullanımı arasında farklılıklar olduğunu belirtir ${ }^{140}$. Zikzak motiflerinin Bizans mimarisinde, özellikle apsis cephesinde 11.-14. yüzyıllar arasındaki yaygın kullanımı dikkati çeker141. Kapıkırı Manastırı, Enez'deki Fatih Camii ve Kariye Manastır Kilisesi niş kavsaralarındaki zikzak motifleri, uygulandıkları yer açısından tartışılması gereken diğer motiflerdir ${ }^{142}$.

J. S. Ćirić, 13. yüzyılda Bizans mimarisinde tuğla işçiliği konulu makalesinde, "Eserler bir hikaye anlatır mı?" sorusunu yöneltir. Bizans kiliselerinde özellikle apsis cephesinde yer alan görsel imgelerin, izleyen kişiler için nasıl bir anlam ifade ettiğini sorgular143. Bizans

131 Trkulja 2011, 224, 227.

132 Tomoioagă 2015, 142-153; Ćurčić 2012, 312.

133 Ćurčić 2012, fig. 11. 8-9.

134 Örnek için bk. Ötüken 1978, 228, fig. 27.

135 Fotoğraf için bk. Ötüken 1978, 228, fig. 27; Ioannes Hrisostomos'tan aktarım için bk. Peña 1997, 174.

136 Peña 1997, 157.

137 Danık 1997, 190, fig. 3.

138 Konstantin Lips Manastırı Güney Kilisesi için bk. “Monastery of Lips,” 2020. Peribleptos Meryem Manastır Kilisesi için bk. "Grande Flânerie," 2020.

139 Hoddinott 1963, 67, fig. 38-39.

140 Testere dişi kullanımı için bk. Ötüken 1978, 220.

141 Mercangöz 1992, 88.

142 Kapıkırı için bk. Mercangöz 1992, 88, lev. XXXIII; Enez için bk. Eyice 1969, fig. 31; Ousterhout 1985, 264, fig. 8; Ousterhout 1987, 29, fig. 136, 138-139.

143 Ćirić 2016, 307. 
kiliselerinin duvarlarındaki imgeler, gerçekte yaratıldığ1 dönemdeki toplum için günlük veya dini yaşamın bir parçası olarak, ortak bir belleğe ait öğrenilmiş anlamlar taşır mı? Tuğla rozet/güneş motifi bugün "sıradan anlamıyla" tuğladan yapılmış bir bezeme olarak algılanabilir. Fakat asıl anlamı, dönemi içinde gerçekte ne ifade ettiğidir. Dionysius'a göre özne ve nesneyi aşan mistik birlik inancına sahip, afomoioz (asimilasyon) ve henosis (birleşme) kavramları Tanrı'ya ulaşmak için bir araçtır ${ }^{144}$. 'Rozet motifinin asimilasyonu ve geçmişte Tanrı ile ilişkisi bu bağlamda nasıl kurulmuştur?’ şimdi bu sorunun cevabını tartışacağız.

\section{Rozet Motifi ya da Yenilmez Güneş/Sol Invictus?}

inventori lucis soli invicto augusto

"Işı̆̆ın yaratıcısı olan fethedilemez güneşi yüceltiyorum"145

Geç Roma Dönemi'nde imparatorluğun batısındaki şehirlerin surlarında, tuğladan yapılmış ışınsal rozetler görülür. H. Dey tarafından "daireler" veya "yarım daireler" olarak adlandırılan rozetler, 3. yüzyıl ve sonrasına tarihlendirilir. Surlardaki yarım oval örnekler, Roma duvarlarının erken evrelerinde (271-280 arası ve ayrica 401-403), yarım daire olanlar Fransa'da Daks'ta 4. yüzyılın üçüncü çeyreği, Carcassonne'de 400 civarına, İtalya'da Ravenna'da 5. yüzyılın ilk yarısına tarihlenir${ }^{146}$. İtalya'da Terracina'nın 5. yüzyıl surlarında ayrıca yarım ve tam daire ışınsal motifler bulunur ${ }^{147}$. Köln surlarındaki örnekler yalnızca bir süs öğesi olmanın dışında, merkezi bir noktadan yayılan "ışı̆̆ın sembolü" olarak tanımlanır ${ }^{148}$. Işık unsuru ile ilişkili olarak dairelerin güneşi, yarım dairelerin ise ay veya güneşin doğuşunu sembolize ettiği düşünülmektedir ${ }^{149}$. Bu örnekler, olasıllkla Ankara Kalesi'nde Bizans Dönemi'ne tarihlendirilen ışınsal rozetin proto-tipi olmalıdır ${ }^{150}$. Surlarda görülen ışınsal tuğla rozetlerin bezeme öğesi olması dışında 3. yüzyıldan itibaren Roma İmparatorluğu'nun yaygın inancı olan "güneş kültü" ile bir ilişkisi var mıdır?

Roma Dönemi'nde Suriye'de güneş inanc1, İmparator Septimus Severus Dönemi'nden (MS 193-211) Julian Dönemi'ne (MS 360-363) kadar bilinçli bir imparatorluk politikası olarak görülür. Bu politikayı destekleyen imparatorların bazılarının Suriye kökenli olduğu veya bu inanıştan etkilenmiş oldukları belirtilir151. MS 274 yılında İmparator Aurelian tarafından, Suriye'den (Emesa) Roma'ya taşındığı sanılan Sol inancı (Yenilmez/Fethedilmez Güneş), Roma İmparatorluğu'nun resmi inançlarından biri haline gelir152. İmparator Aurelian (MS 270-275) Suriye'de Palmyra'da Tadmor Kraliçesi Zenobia'nın ordularına karşı yürüttüğü sefer sırasında kendisine görünen "ilahi imgeyi" içeren vizyonun Roma'ya, daha sonra da tüm imparatorluğa yayılmasını sağlar153. Bu tarihten önce Roma'da MS 2. yüzyılda, antik Palmyra kentinin güneş tanrısı olarak bilinen

\footnotetext{
144 Lossky 1997.

145 Guarducci 1957/1959, 161-169.

146 Dey 2010, 3-37.

147 Terracina şehir surlarındaki tam daire motif için bk. Dey 2010, 32, fig. 7.

148 Dey 2010, 16, fig. 4.

149 Dey 2010, 3-37.

150 Serin 2014, 75, fig. 10.

151 Suriye'de Emesa (bugünkü Humus) rahiplerinin soyundan gelen Julia Domna'nın pagan güneş unvanlarını taşımasına izin verilir. Septimus Severus güneş tanrısı Helios ile özdeştirilir. İmparator Elagabalus (MS 218-222) gençliğinde Helios/Sol rahibidir; ayrıca Heliogabalus unvanını taşır. Güneşe kurbanları sunacak kişi olarak tasvirlerinde Sol rahibi olarak giyinir. Sol kültü ile ilgili detaylı bilgi için bk. Halsberghe 1972; Hijmans 2009; Hijmans 2011.

152 Hijmans 2011, 139-152; “Quora,” 2020.

153 Hijmans 2009, 504-505.
} 
Malakbel'e adanmış bir tapınak olduğu bilinir. Aurelian tarafından Roma'ya taşınan bu inanış, güneş tanrısı Deus Sol Sanctissimus olarak bilinen Sol ile özdeştirilip, Yenilmez/Invictus sıfatına sahip olur ${ }^{154}$. Aurelian, 25 Aralık 274'te Roma'da Sol'e adanmış bir tapınak inşa ederek, içine Palmyrene İmparatorluğu'na karşı kazandığı zafer sonrası Suriye'den getirdiği güneş tanrısının heykelini koymuştur ${ }^{155}$.

Sol Invictus'un Elagabalus (Helios/Sol) kültünün devamı veya Palmyra kentinde inanılan Malakbel'in, Roma tanrısı Sol ile özdeştirilmiş hali olduğu düşünülür156. Güneş inancının Hristiyanlığa nasıl uyarlandığı konusunda ek bir bilgi olarak vermek gerekirse; Bizans'ta pek çok Hristiyan bayramının, Hellenistik tanrılar, güneş tanrısı, Sol ve İsa'nın senkretizmi -yani eskiyi yeniye uyarlama- sonucu kutlandiğı kabul edilir. Bu bağlamda İmparator Aurelian tarafından Roma'da Sol adına yaptırılan tapınak, 25 Aralık 274 günü adanmıştır. Bu tarihten sonra 354 yılındaki takvime göre 25 Aralık Natalis Invicti Festivali olarak, Hristiyanlıkta ise İsa'nın doğumu olarak kutlanır ${ }^{157}$. Güneş festivali, 4. yüzyılda pek çok Hristiyanın halâ kutladığı pagan bayramlarından birisidir. Bu inanışın, Hristiyanlığın yükselişini ciddi şekilde tehdit ettiği varsayımı, İsa'nın doğum gününün 25 Aralık olarak tercih edilmesinde etkili olmuştur. Bir diğer düşünceye göre ise güneş kültünün Hristiyanlık için bir rakip olarak, olasılıkla varlığını uzun süre sembollerle sürdürmeyi başardığıdır158.

Güneş kültü Roma İmparatorluğu'nun sonuna doğru iyice benimsenerek, en kuvvetli inançlardan biri haline dönüşmüştür. Öyle ki 3. yüzyılda Filistin'deki Hristiyan ve Yahudi toplulukları dahi Greko-Romen kökenli güneş tanrısı inancının etkisi altında kalmışlardır. Geç Roma ve Erken Bizans Dönemi'nde Filistin'deki Yahudi toplulukları arasında bu inancın benimsendiğini gösteren arkeolojik kanıtlara ulaşılmıştır. Tiberias'taki Hammath Sinagogu'nda, MS 3. yüzyıl sonları veya 4. yüzyılın başlarına tarihlendirilen mozaikte, aynı yüzyıllarda Beth-Apha Sinagogu'nda eski güneş tanrısı Helios tasvir edilmiştir159. Bu inanışın sadece Hristiyanlık değil, Yahudi toplumu üzerinde kültürel ve dini bir tehdit oluşturduğu düşünülür160. Sepphoris'teki bir başka sinagogun zemininde, 6. yüzyıla tarihlenen bir mozaikte, Helios' un arabası görülür ${ }^{161}$. Sinagoglardaki bu tasvirlerin buradaki toplumlar tarafından pagan inançtan bağımsız, mistik bir inanışın sembolü olarak algılandığı sanılmaktadır. Yahudilikteki tasvir yasağına rağmen, Geç Roma Dönemi'nde Filistin bölgesinde güneş inancl, Yahudi olmayan bir kült olarak ritüelleriyle birlikte yaşamaya devam etmiştir162. Hristiyanlıkta güneş inancının yansımalarının nasıl olduğunu anlamak için antik dönemdeki ritüeller incelenmelidir.

Erken Hristiyanlık Dönemi'nde ışığın sembolizmine duyulan ilgi, Geç Roma Dönemi'nin son pagan imparatorlarıyla ilişkilendirilir. Antik Roma'da imparatorların askeri bir sefer sonrası şehre kabul edilmesi olan adventus (varış/şehre giriş) töreninde imparatorlar kente geldiklerinde, onları karşılayanlar ellerinde meşale ve kandiller taşırlar. Galerius'un Selanik'e girişinde kutlanan adventus töreninde kapıda iki meşaleci tarafından

\footnotetext{
154 Hijmans 2003; Watson 2004, 196;

155 Hijmans 2009, böl. 5; Dirven 1999, 169. Güneş inancının Suriye kökenli olduğu inanışı yaygındır. Bk. Hijmans $2009,485$.

156 Halsberghe 1972, 156. Güneş inancı elbette çok eski geçmişe sahip ve pek çok kültürde var olan bir inanıştır. $\mathrm{Bu}$ inanışla ilgili yapılan bir çalışmada maalesef Sol inancı atlanmıştır. Bununla birlikte inanışın yaygınlığı ve kökeni konusunda zengin bir fikir sunar. Bk. Şen ve Gürpınar 2019, 985-1008.

157 Hijmans 2003, 377-398; Hijmans 2011, 139-152.

158 Hijmans 2011, 139-152.

159 Friedheim 2009, 91.

160 Friedheim 2009, 91-92.

161 Friedheim 2009, 93.

162 Friedheim 2009, 93-94.
} 
karşılanmıştır ${ }^{163}$. Geç Roma Dönemi pişmiş toprak kandilleri üzerinde ışığın sembolü olarak güneş tanrısı Helios/Sol tasvirleri görülür164. Güneşin evrenin ana tanrısı olarak Roma'nın koruyucusu olma sıfatı, 3. yüzyılda en üst seviyeye ulaşır. İmparatorlar kendilerini yeryüzünde güneşin temsilcisi olarak görür. Tıpkı güneş ışınlarının yeryüzünün en ücra köşelerine ulaşması gibi imparatorluk egemenliği altındaki en uzak coğrafyalara kadar erişir165. MS 3.-4. yüzyıllar arasındaki Roma imparatorlarının çoğu, sikkelerinde başlarında güneşi simgeleyen, 1şınlı bir taçla tasvir edilmişlerdir ${ }^{166}$. 4. yüzyıla ait yazılı ve görsel kaynaklarda I. Konstantin' in (MS 306-337) yoğun olarak güneş ve 1şık ile özdeştirilen imajından söz edilebilir. Öyle ki Büyük Konstantin “Imparatorluğun gerçek ışı̆̆ı/uera imperii lux" olarak tanımlanır ${ }^{167}$. Augustodunum'a (Autun) şehrine girişi sırasında İmparator'un parıldayan 1şık, yani güneşin kendisi olarak görüldüğü şu sözlerle aktarılır: "Ölümsüz Tanrılar, bize ne gün parladı... Kurtuluşumuzun ilk belirtisi olan bu şehrin kapılarına girdiğinizde"168.

Bilindiği üzere I. Konstantin'in Hristiyan olup olmadığı sorunu tartışmalıdır169. I. Konstantin Hristiyanlığı yasallaştırmasına rağmen, üzerinde pagan tasvirlerinin görüldüğg̈ sikkeler bastırmaya devam etmiştir. Bu bağlamda imparatorun halâ güneş tanrısı Sol'a bağlılığını gösteren kanıtlar sunulabilir ${ }^{170}$ Roma'da basılan bir grup nadir sikke üzerinde Sol Invictus, elinde tuttuğu kozmosu (küre) Konstantin'e sunarken tasvir edilir. Sikkenin üzerindeki tasvir, Sol'un İmparatora her şeye hükmetme gücünü vermesi olarak yorumlanır171. Roma'da Konstantin'in Zafer Kemeri (312-315) üzerinde güneş tanrısı (Helios), dört atın çektiği quadriga üzerinde gösterilmiştir ${ }^{172}$. 4. yüzyılda ise İsa'nın benzer şekilde bir mozaikte tasvir edilişine şahit oluruz ${ }^{173}$. Bir başka kaynak olan Panegyrics'te (I. Konstantin'e Methiye) I. Konstantin' in doğduğu gün şöyle tanımlanır: "dünyanın yaratılışında hayat verdiği zamandan daha görkemli bir ışık berraklığıyla (parladığını) ... (ve güneşin) (ondan) daha az parlak görünmemek için mücadele ettiğini beyan eder"174. Konstantin'in ölümü ve göğe yükselişini ise şu sözlerle aktarır: “Günȩ̧ (Konstantin)'i, (onu) cennete taşımak için neredeyse görülebilen bir savaş arabasına aldı"175. Kaynakta, güneş tanrısının arabasına binerek göğe yükselen Konstantin efsanesi, aslında İmparatoru pagan değerlere bağlı görmek isteyenlerin yorumu olmalıdır (fig. 30). Bütün bu bağlantılar araştırmacıları Konstantin'in Sol'e bağlılığ1 konusunda ikna eden argümanlardır.

Sol, tasvirlerinde genellikle Helios/Apollon (eski güneş tanrısı) ile karıştırılmıştır ${ }^{176}$. Konstantin Forumu'nun ortasındaki sütun üzerinde I. Konstantin'in Apollon ile özdeştirilen,

\footnotetext{
163 Adventus için bk. Dey 2010, 19-27; ayrıca Klose 2015, 99-116. Galerius'un adventus töreni için bk. Üçer-Karababa 2020, 127-148.

164 Fındık 2019, 186, 11. Ayrıca örnekler için bk. “Terracotta Lamp,” 2020 (Kıbrıs MS 75-125).

165 İmparatorların güneş ile özdeştirilerek tanrısallaştırıldı̆̆ı (divus) bir imparatorluk kültünden bahsedilebilir. Bk. Dey 2010, 32.

166 Roma İmparator taçları için bk. Hijmans 2006, 440-443; Hijmans 2009, 80-84, 509-548.

167 Nixon ve Rodgers 1994, 140

168 “Imperial Panegyrics," 2020.

169 Kaymaz 2014, 213-235; Doğanc1 2017, 493-517.

170 Sol kültü, Aurelian'ın MS 274'te hükmettiğinden beri Roma'nın resmi devlet dini olmuştur; ancak Sol, 193'ten 211'e kadar hüküm süren Septimius Severus'un zamanından beri Roma sikkelerinde görülür. Bilgi için bk. “Constantine the Great Sol Bronzes," 2020; Hijmans 1996, 115-150; Halsberghe 1972; Matern 2002.

171 Fotoğraf için bk. "Constantine the Great Sol Bronzes," 2020. Bilgi için bk. Hijmans 2011, 139-152; Hargrove 2015, 29-30.

172 Marlowe 2006, 236, fig. 19.

173 Fotoğraf için bk. "The god Sol in quadriga," 2020.

174 Nixon ve Rodgers 1994, 111; Hobbs 2014, 11-12.

175 Nixon ve Rodgers 1994, 209; Hobbs 2014, 11-12.

176 “Sol Invictus,” 2020.
} 
Helios şeklinde bir heykeli olduğu bilinmektedir. Kaynaklar Konstantin'in heykelinde başında ışınlı parlak bir taç taktığını, elinde ise mizrak ve küre olduğunu aktarır177. Bazı araştırmacılar Konstantin'in elindeki küre ve mızrağın imparatorun birleştirici yönetimi ve gücünün sembolü olduğunu öne sürer178. Bununla birlikte Konstantin'in heykeli kanımızca eski güneş tanrısı Helios'tan çok, 4. yüzyılda halâ güçlü bir şekilde tapılan Roma'nın Yenilmez Güneş Tanrısı/Sol Invictus'a ait olmalıdır. Heykelin çıplak oluşu, pozu, elinde tuttuğu düşünülen küre (yani kozmos) Konstantin'in Yenilmez Güneş/Sol ile özdeştirilmiş olduğunu düşündürür. Konstantin'e ait soli invicto comitide Sol, çıplak olarak başında ışınlı taç ve bir elinde küre (çok

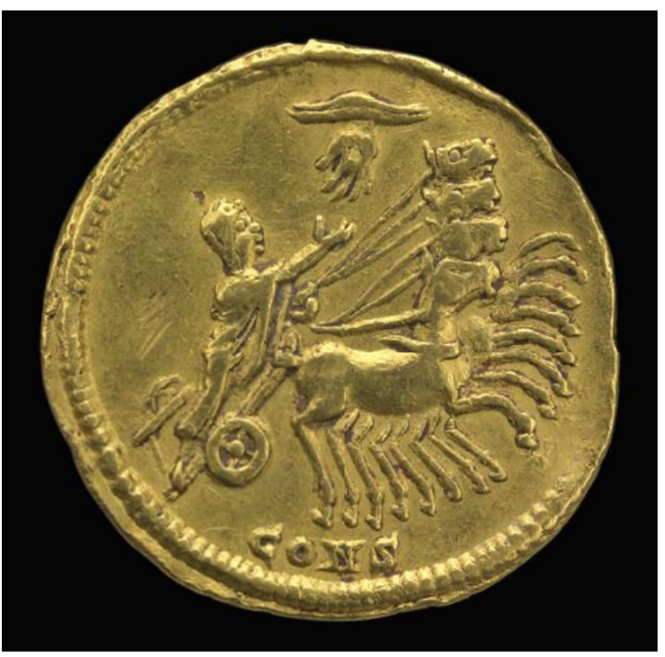

Figür 30: Konstantin'in Göğe Yükselişi (Altın sikke, MS 337, British Museum, Env. no. 1986, 0610.1) az örnekte mızrak) tutarken görülür179. Ayrıca Hesychius ve Leo Grammaticus'un "Güneş gibi parlayan Konstantin'e" diye yazdıkları ithaf yazıtında, İmparator'u Tanrı Sol ile özdeştirdiği varsayılabilirr180. Paskal Kroniği'nde, Konstantin'in forumun ortasındaki sütuna heykelin dikilişini "...Sütunun tepesine, başında ışınlar taşıyan kendi heykelini koydu..." sözleriyle anlatır ${ }^{181}$. Heykelin en erken tasviri Roma Dönemi'ne ait Tabula Peutingeriana'nın 12. yüzyıl kopyasındadır. Burada çıplak olarak tasvir edilen figürün başında taç görülmez ${ }^{182}$. İmparatorların özellikle öldükten sonra tanrılaştırılması pagan kültürde bilinen bir gelenek olduğundan, kahramanlaştırılan imparatorun çıplak olarak tasvir edilmesi için heroik bir çıplaklık kavramından söz edilebilir183. Konstantin heykelinin Sol ile özdeştirilmesi konusundaki görüşümüze paralel bir düşünce, R. Ousterhout tarafından Konstantin'in sütunu ve heykeli ile ilgili makalede tartış1lır ${ }^{184}$. Dönem tarihçileri de dahil heykeli Hristiyanlıkla bağdaştıranların savunduğu, Konstantin'in başındaki tacın bizzat kendisinin Kudüs'ten getirttiği gerçek haçın çivileri olduğu ve burada gerçekte İsa ile özdeştirildiğidir185. Roma'da paganlar için Sol kültünün ortaya çıkışında geçmişteki inanışların dönüşümünde yaşanan Hristiyanlıkta farklı olmayacak, erken evrelerde İsa aynı zamanda Sol ile özdeştirilecektir.

Roma'da I. Konstantin Dönemi'nde yapımına başlanan ve yaklaşı 30 yıl sonra tamamlanan Eski Petrus Bazilikası'nın (MS 326-333, 360) altındaki nekropol alanında Mousoleum M olarak bilinen yapının tonozunda 3. yüzyılın sonuna ait bir mozaik bulunur (fig. 31). Bazı araştırmacılara göre bu mozaikte quadrigayı sürmekte olan güneş tanrısı Helios/Sol veya İsa'nın kendisi eski pagan tanrılar gibi tasvir edilmiştir186. İsa'nın kutsallığını artıran başındaki halesinin etrafından ışınlar yayılmaktadır ${ }^{187}$. Buradaki figürün

\footnotetext{
177 Bassett 2004, 203.

178 Bardill 2011, 166.

179 Hijmans 2011, 139-152; Hargrove 2015, 29-30.

180 Orijinal kaynaktan alıntı için bk. Yoncacı-Arslan 2016, 126.

181 Türkçe aktarım için bk. Freely ve Çakmak 2005, 22.

182 Ousterhout 2014, 311, fig. 6; Yoncac1-Arslan 2016, 136, fig. 15.

183 Drake 2016, 1-17.

184 Ousterhout 2014, 311-312.

185 Yoncac1-Arslan 2016, 125-126.

186 Ćurčić 2012, 309.

187 Grabar 1968, 80; Ćurčić 2012, 309. İsa'nın göğe yükselişinin antik yorumu olan mozaikte, İsa 'iyileştirici
} 
İsa ile özdeştirilmesindeki argümanlardan birisi, İskenderiyeli Klement'in İsa'nın arabasını gökyüzüne doğru sürdüğünü belirtmesi olmalıdır188. Hâlbuki Konstantin'in Roma'daki Zafer Takı'nda (MS 312-315) güneş tanrısı (Helios/Sol) bir quadriga üzerinde gösterilmiştir ${ }^{189}$. İngiltere' de Dorset kentinde Hinton kasabasında St. Mary Roma villasındaki 4. yüzyıla ait bir mozaikte İsa, kimliğini açıkça ortaya koyan, başının arkasında ışın şeklinde $X-P$ monogramı ile tasvir edilmiştiri190. İsa ve Tanrı'nın ilahi bir ışık olarak tasvir edilmesi, İncil'deki şu cümlelerle anlatılır: "Işı̆̆ga sahipken Işı̆̆a iman edin ki, Işık çocuklar olasınız" (Yahya 12:36). İsa' nın Metamorphosis sahnesindeki ışınlar saçan tasvirlerinin kaynağı ise Matta'nın (17:2) şu sözleridir: “Onların gözü önünde İsa'nın görünümü değişti. Yüzü güneş gibi parladı, giysileri ışık gibi bembeyaz oldu." S. Y. Ötüken, Aziz Nikolaos Kilisesi kuzeybatı alanda ortaya çıkarılan ve duvar örgüsünde devşirme olarak kullanılan bir kemer aynasındaki haç motifinin kolları arasında PWC ve ZHW harflerini okur. 6. yüzyıla ait bir kemer taşında haç kolları arasındaki bu harfler "1şık ve yaşam" anlamı taşır ki ilahi ışığın sembolizmine dikkati çeker ${ }^{191}$. Bütün bu veriler, İsa'nın Hristiyanlığın ilk yüzyıllarında ışığın kendisi veya kaynağı olan güneşle bağdaştırılmaya çalışıldığına dair yalnızca birkaç örnektir.

Hristiyanlığın resmi din olmasından çok sonra dahi güneşin, pagan tanrıları Helios/Sol şeklinde tasviri özellikle Batı Hristiyan sanatında devam etmiştir. 9. yüzyıla ait Viyana ve 11. yüzyıl Reichenau el yazmasında İsa'nın Çarmıha Gerilişi sahnesinde güneş, başında 1şınlarla bir insan figürü (olasılıkla Helios/Sol) olarak betimlenmiştir. 11. yüzyılın ikinci yarısına ait İsa'nın vaftizini gösteren fildişi bir eser üzerinde de güneş, başında 1şınlı bir taçla pagan tasvirlerindeki gibi görülür ${ }^{192}$. Bu tasvirlerin çoğaltılacağı örnekler göz önüne alınırsa, pagan inanışların Hristiyanlıkla ilgili sahnelerde Geç Antik Dönem'de olduğu gibi kişileştirilmiş figürlerde yaşaması, Orta Çağ'da güneş sembolünün halâ devam edebileceğinin kanitı olarak sunulabilir.

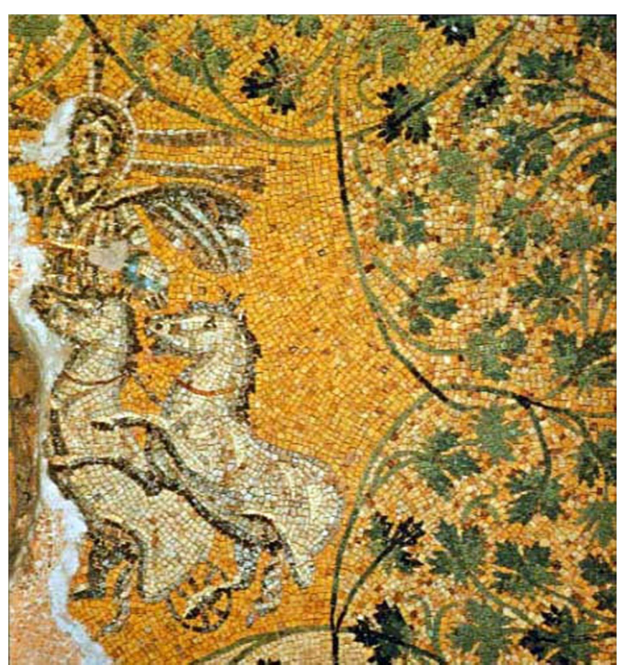

Figür 31: Roma, Eski Aziz Petrus Bazilikası Mousoleum M mozaik

Işığın mimaride nasıl betimlenebileceği sorunu, tuğla rozet/güneş motifleri ile çözülmüş olmalıdır. Rozet motifleri diğer tuğla süslemeler gibi yapıların cephesini hareketlendiren bir süs unsuru olarak algılanabilir. Bununla birlikte yapıların çoğunda cephede rozetlerle birlikte tuğladan yapılmış haç motiflerinin olması dikkati çeker. Elbette dini bir yapıda haç motifi beklenebilir ancak her iki motifin birlikte kullanılmasının sembolik bir anlamı olabileceği görüşümüz, Girit Adası'ndaki bir kiliseyi incelediğimiz sırada destek bulur. Girit Adası'ndaki eski bir hamam yapısının olasılıkla 13. yüzyılda kiliseye (Kato Episkopi Siteias) dönüştürüldüğü bilinmektedir. İlginç bir şekilde bu dönüşüm sırasında doğu cephedeki kör kemerler içine tuğladan yapılmış iki rozet ve bir haç motifi eklenmiştir ${ }^{193}$ (fig. 32). Rozetlerin orijinal yapının parçası olduğu ve Orta Bizans Dönemi'ne tarihlendirildiği gibi farklı görüşler bulunur. N. Poulou ve A. Tantis ise haç ve rozetlerin

1şınlarıyla birlikte adalet güneşi' (Malaki 3:20) ile ilişkilendirilmiştir.

188 İskenderiyeli Klement için bk. Webb 2001, 18.

189 Marlowe 2006, 223.

190 Ćurčić 2012, 309, 11.1.

191 Ötüken 2007, 131-136; Ötüken 2002, 33, fig. 2.

192 Genişletilmiş örnekler için bk. Kırıkçı 2004, fig. 24, 25, 27.

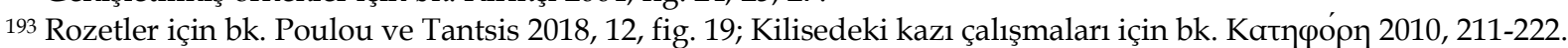


özellikle yapının dönüştürülmesi ile ilişkili olarak, bir hamam düzeninin parçası olmaktan ziyade kilise için daha uygun olduğu görüşünü öne sürerler ${ }^{194}$. Haç ve rozet/güneş motifinin bir arada betimlenmesi tesadüf değil, Orta Çağ'daki kullanıcıları tarafından bilinen sembolik bir anlam taşıyor olmalıdır. Sakız Adası Nea Moni Kilisesi'nin kör kemer köşelerinde güneş ve haç motifinin karşılıklı olması, aynı sembolik anlama bağlı olmalıdır ${ }^{195}$ (fig. 33).

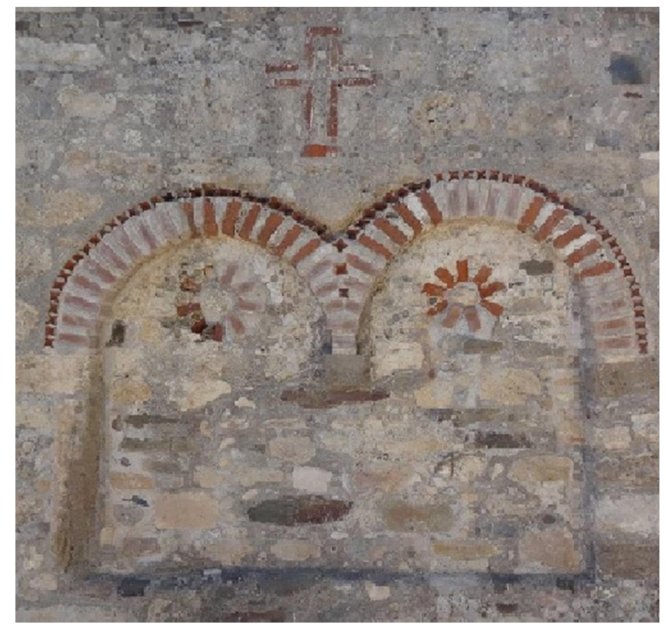

Figür 32: Girit Adası Kato Episkopi Siteias Kilisesi doğu cephe rozet ve haç motifi

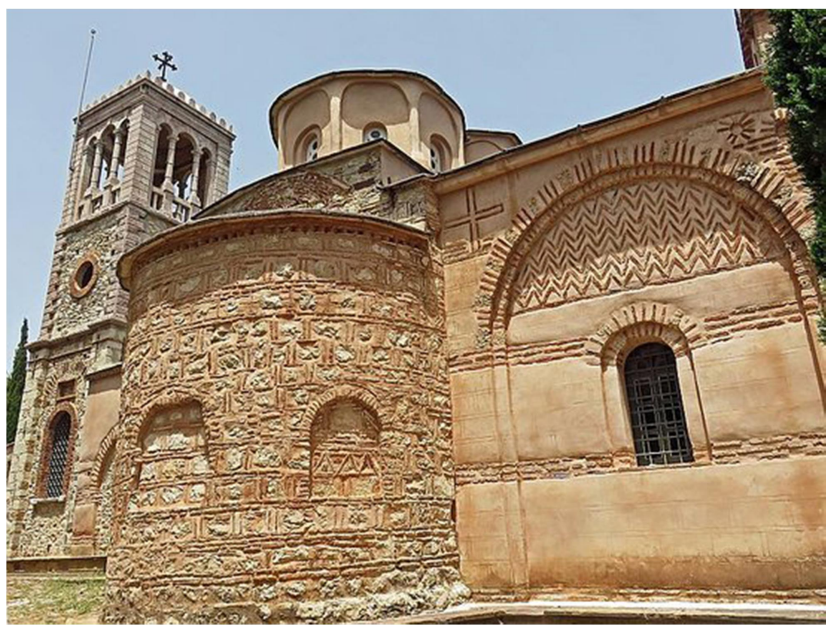

Figür 33: Sakız Adası Nea Moni Manastır Kilisesi'nin cephesindeki haç ve güneş motifi

Orta ve Geç Bizans mimarisinde tuğlanın yoğun kullanıldığı yapılardaki bezeme unsurlarından biri de swastika/gamalı haç motifidir. İncelediğimiz yapılar arasında swastika/gamalı haç motifi Kostantinpolis'teki Konstantin Lips Manastırı, Philantrophos İsa Manastırı, Gebze Eskihisar Kalesi'nin kuzeybatısındaki dört katlı kule gibi yapılardan bilinmektedir ${ }^{196}$. Bu motifin güneşin gökyüzündeki hareketini temsil eden sembolik anlamı, İslam sanatında olduğu gibi, sonsuzluğu çağrıştıran geometrik motiflerin ilahi olanla ve evrenle ilişkisi ile benzerlik taşımaktadır ${ }^{197}$.

Tuğla rozetlerin görüldüğü yapıları incelediğimizde, İstanbul'da Studios Manastırı, Olympos Episkopeion peristyl çeşmesi, Selanik Galerius Sarayı'ndaki oktagon yapının yanı sıra tuğla rozet/güneş motifleri yaklaşık 18 yapıda haç motifi/Chi-Ro monogramı ile birlikte kullanılmıştır. Bununla birlikte rozetlerin ortasındaki kısımlarda Bulgaristan'da Misivri Sv. Ivan Aleiturgetos Kilisesi, Pammakaristos Manastırı'nda (Fethiye Cami) olduğu gibi bazı örneklerde orijinalde haç motifi ya da monogram olduğu sanılmaktadır ${ }^{198}$. Yapıların işlevine bakmaksızın tuğladan yapılmış ışınsal rozetler ile haç motifinin birlikte kullanılmasının bir sembolik anlamı olabilir mi? Bu konuyu açıklayabilmek için Geç Roma'nın inanç sistemindeki değişime kısaca göz atma gereği duyuyoruz.

Selanik'te Galerius Sarayı'ndaki oktagon yapının kuzey nişinde yer alan palmiye dalları arasında, merkezinde haç bulunan rozet motifi hakkında çeşitli görüşler öne sürülür. C. Makaronas, bu motifin Hristiyan kökenli ustalar tarafından gizlice yapıldığını öne sürer ${ }^{199}$. B. Hoddinott, eş kollu haçta 1şınlarla çevrili "güneş tanrısı ve ateşli arabası" sembolünü görmüştür. Bitkisel motiflerin ise Mithras tarafından öldürülen boğanın ölümcül

\footnotetext{
194 Poulou ve Tantsis 2018, 11.

195 Fotoğraflar için bk. "Nea Moni,” 2021.

196 Bahar 2013, 28, fig. 61, 165, fig. 133, a-c. 28. Fotoğraflar için bk. "Monastery of Lips,” 2020; “Monastery of Christ Philanthropos," 2020.

197 Gamalı haçın kısaca sembolik anlamı için bk. "Gamalı Haçın Tarihi," 2021.

198 Ötüken 1978, 223, fig. 17, 224, 232, fig. 35.

199 Makaronas 1969, fig. 29.
} 
yarasından olan, doğurganlığın sembolü misır başakları olabileceğini öne sürmüştür ${ }^{200}$. M. Vickers, Palmyrene Sol Tapınağı'na ait sunağın üzerindeki selvi dallarına dayanarak, B. Hoddinott'un görüşünün desteklenmesi için motifin selvi olarak tanımlanmış olması gerektiğini belirtir ${ }^{201}$. M. Vickers, farklı araştırmacılar tarafından bitkisel süslemenin selvi veya hayat ağacı olarak tanımlandığını ancak pagan ve Hristiyanlar için zafer anlamı taşıyan "palmiye dalı" olabileceğini savunur. Araştırmacı, oktagondaki haç ve palmiye motifinin birlikte ne anlama gelmiş olabileceği sorusunu yöneltir ${ }^{202}$. New York Metropolitan Müzesi'ndeki 2.-3. yüzyıllara ait bir gemme üzerinde, bir elinde küre ve kırbaç tuttuğu düşünülen güneş tanrısı Helios/Sol tasvir edilmiştir203. Figür, palmiye dalına benzer şekilde bezemeli bir quadriga üzerinde yer almaktadır. Atlar ikişerli gruplar

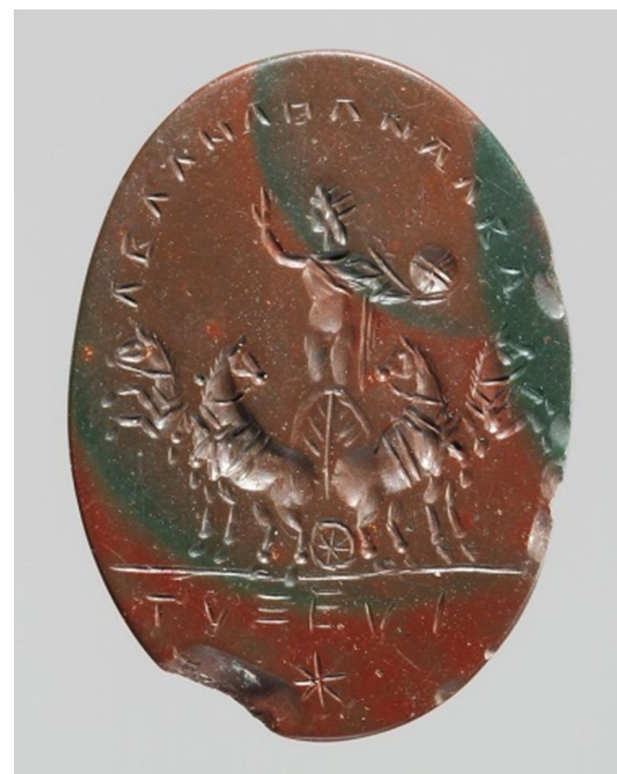

Figür 34: New York Metropolitan

Müzesi'nde bulunan arabasını süren Sol tasvirli gemme (Env. no. 816.297) halinde yanlara doğru dönmüş, ortada ise quadriganın tekeri bulunmaktadır (fig. 34). Galerius oktagonu dişında incelediğimiz yapıların bazılarında tuğla rozetlerle birlikte karşılaştığımız palmiye dalları, gerçek anlamı unutulmuş olsa bile, antik sanatın yaşamaya devam eden sembolleridir. Gemmenin diğer yüzünde ise Zafer Tanrıçası Nike tasvirinin bulunması, palmiye dallarının 'zaferi' sembolize eden anlamiyla örtüşür.

Erken Hristiyanlık Dönemi'nden itibaren yapıların cephesinde haçla birlikte güneş motifinin kullanılması, Milvian Köprüsü Savaşı sırasında gerçekleşen I. Konstantin'in vizyonu ile bir ilişkisi olabilir mi? Bu anlamda savımıza en yakın düşünce, M. Vickers tarafından ortaya atılmış olup, Selanik oktagonunda palmiyeler arasındaki haçın I. Konstantin'in rüyası ile ilişkili olarak "Haçın Zaferi" ni simgeliyor olabileceğini öne sürmüştür ${ }^{204}$. Araştırmacı, aşağıda tartışılacak olan savımızla paralel olarak, Konstantin'in vizyonunun muhtemelen Erken Hristiyanlık Dönemi'nde iyi bilinen bir efsane olduğunu belirtir. Ancak M. Vickers, bu görüşü tartışmaksızın Selanik oktagonundaki rozeti, Galerius'un Hoşgörü Fermanı sonrası yapılmış olmasına bağlar205. 311'de Galerius'un 'Hoşgörü Fermanı' ilan edildiğinde sarayın inşasının devam ettiğini, haçın ve palmiye sembollerinin bu sırada yerleştirilip, üzerinin kapatılmış olabileceğini öne sürer ${ }^{206}$.

İmparator Galerius tarafından, I. Konstantin'den iki yıl önce, MS 311 yılında Nikomedia'da (İzmit) yayınlanan Hoşgörü Fermanı, Hristiyanlara kendi inançlarında

\footnotetext{
200 Bilgi için bk. Vickers 1973, 115; aynı zamanda Sol Invictus, bir başka güneş inanışı olan Mithras ile özdeştirilmiştir. Bk. Hoddinott 1963, 123-124.

201 Vickers 1973, 114, fig. 9, 115, dn. 23.

202 Vickers 1973, 116. Palmiye dalları için bk. “Oktagon North Niche,” 2020.

203 B. Hoddinott'un olasılıkla güneş tanrısının ateşli arabası olarak kastettiği sembol, MET'te bulunan taşın üzerindeki tekerleğe benziyor olmalıdır. Hoddinott'un görüşlerini bir adım daha ileri götürecek olursak; güneş tanrısının arabasını çeken atların ayak hareketi yan yana dikey zikzak oluşturur ki bu Sille Aya Elena Kilisesi'nin kubbe kasnağındaki dikey zikzakları anımsatır. Bk. "Probus, Antoninianus," 2021. New York Metropolitan Müzesi'ndeki taşın fotoğrafı için bk. "Jasper intaglio," 2021.

204 Vickers 1973, 111-120, fig. 9; Athanassiou et al. 2006, 247, fig. 4. Fotoğraf için bk. “Oktagon North Niche,” 2020.

205 Vickers 1973, 116

206 Vickers 1973, 116.
} 
sağlanan hakları kapsar. Bu bildiri Lactantius (MS 250-325) tarafından 'De mortibus persecutorum' adlı eserde yayınlanır ${ }^{207}$. Bu tarihten iki y1l sonra ise 313 yllında, I. Konstantin ve Licinius tarafından Nikomedia'da yayınlanan Milano Fermanı ile Hristiyanlara inançlarında serbestlik getirilmiştir. Bu olay, I. Konstantin'in 28 Ekim 312 yılında Milvian Köprüsü'nde rakibi Maxentius'a karşı kazandığı zaferden bir yıl sonradır208. Eusebius ve Lactantius'a göre I. Konstantin'in zaferi Hristiyan Tanrı' ya inancından kaynaklanmıştır. I. Konstantin'in Milvian Köprüsü Savaşı öncesinde gördüğü vizyonu, Vita ve Mortibus'ta aktarılır ${ }^{209}$. Rozet/güneş motifi ile Konstantin'in vizyonu arasında ilişki kurmamızı sağlayan hikâye ise, Konstantin'in dini politikaları açısından önemli bir kaynak olan Eusebius'un Vita Constantini'sinde yer alır (Eus. vita Const. 1, 27-32). Eusebius, I. Konstantin'in Vitası'nda haçın görünmesi olayını şöyle anlatır: "Güneşin tepede olduğu bir gün gökyüzünde güneş ışı̆̆ından oluşan bir haç işareti (Labarum veya Chi-Rho) gördüm ve altında güneşten bir yazıyla 'Bununla zafere ulaşacaksın' yazıyordu' (Eus. vita Const. 1, 27-32)210. Bu bilgi Lactentius'ta aktarılmamakla birlikte, her ikisi ertesi gece yaşanan vizyona sahiptir. Buna göre I. Konstantin rüyasında, İsa'nın karşısında durduğunu ve üzerinde Yunan alfabesinde Chi ve Rho harflerinin iç içe geçmesiyle oluşan labarum olduğunu görmüş; aynı zamanda duyduğu bir ses Konstantin'e bu isim adına fethetmesini söylemiştir (Lact. mort. pers. 44, 4-6). Ertesi gün savaşa üzerinde labarum olan bir sancakla ayrıca askerlerden bazıları kalkan ve miğferlerine İsa'nın sembolünü (X-P monogramı) boyayarak katılırlar ${ }^{211}$. I. Konstantin bu savaşta rakibi Maxentius'u yenerek, İmparatorluğun kontrolünü ele geçirmekle kalmamış, Milano Fermanı' nda Hristiyanlığa serbestlik getirmiştir: "Ve yine Hiristiyanların sadece toplana geldikleri yerleri ve sadece bireysel mülkiyetleri değil fakat aynı zamanda mensubu olduklar tüzel kurumlara -yani özel şahıslara değil, kiliselerine-ait olduğu bilinen yasal mülkiyetlerinin de yukarıda açıkladığımız hukuk çerçevesinde, hiçbir şüphe ve tartışma olmadan aynı Hıristiyanlara yani onların tüzel kurumlarma ve cemaatlerine geri verilmesini emredeceksiniz"212. Bu tarihten sonra İmparatorluğun her yerinde kiliseler inşa edilmeye başlanmıştır. Kanımızca Konstantin'in askerlerinin kalkanlarına boyadığı $X$ ve $P$ harflerinden oluşan monogram, 6. yüzyılda Justinianos ve Belisarius tarafından Akdeniz, İtalya ve Kuzey Afrika'da imparatorluğun yeniden eski gücüne kavuşması anısına askeri başarılarının sembolü olarak, St. Vitale'deki mozaikte askerlerin kalkanları üzerinde bir kez daha tezahür eder ${ }^{213}$. Aslında Konstantin'in vizyonu, tıpkı İmparator Aurelian'ın (MS 270-275) Suriye'de Palmyra'da Tadmor Kraliçesi Zenobia'nın ordularına karşı yürüttüğü sefer sırasında gördüğü ve sonrasında Güneş Tanrısı/Sol inancının imparatorluğun her yerine yayılmasını sağlayan vizyona benzemektedir ${ }^{214}$. I. Konstantin'in Hristiyanlığı ile ilgili tartışmalarda, bazılarına göre I. Konstantin Hristiyanların desteğini alarak bu olayı politik ve askeri bir zafere dönüştürmek için kullanmıştır ${ }^{215}$. Doğruluğu tartışmalı olmakla beraber Vita Constantini'de haçın güneşten gelen bir ışık şeklinde olduğu vurgusu, bu ilahi olguyu öylesine kuvvetlendirir ki her iki inanç mensuplarını zafere ulaştıran bir motivasyona dönüşür. I. Konstantin'in asker olarak tasvir edildiği sikkelerde, başındaki miğferin üzerinde olasılıkla güneş/yıldız şeklinde bir sembol bulunur. Benzer şekilde Geç Roma kalkan ve armaları üzerinde güneş motifinin

\footnotetext{
207 Hoşgörü Fermanı'nın Türkçe çevirisi için bk. Çalık-Ross 2017, 144.

208 Milvian Köprüsü Savaşı için bk. Hobbs 2014, 4, dn. 13.

${ }^{209}$ Eusebius ve Lactentius' un kaynaklarından aktarımlar için bk. Hobbs 2014, 4-9.

210 Odahl 2004, 83-84; Laughlin 2007, 7.

211 Laughlin 2007, 7.

212 Kaçar 2013, 49.

213 Fotoğraf için bk. "Emperor Iustinianus," 2021.

214 Aurelian'ın vizyonu için bk. Halsberghe 1972; Hijmans 2009; Watson 2004.

215 Kaymaz 2014, 221.
} 
bulunması olasıdır ${ }^{216}$. Bunun en önemli nedenlerinden biri Sol'un imparatorluğun resmi güneş tanrısı olarak askerlerin koruyucusu olmasıdır217.

I. Konstantin'in Milano Fermanı ve Milvian Köprüsü Savaşı, Roma'daki Hristiyanların kaderi için bir dönüm noktasıdır. Bu durum I. Konstantin'in önemli tarihi bir kişilik olarak Batı Hristiyan sanatında sıklıkla tasvir edilmesine neden olmuştur. 16. yüzyılda Raffaello Sanzio da Urbino'nun öğrencisi Guilio Romano tarafından yapılan Milvian Köprüsü Savaşı (1517-1524) adlı resimde I. Konstantin, başında güneş şeklinde ışınlar çıan bir taçla resmedilmiştir218 (fig. 35). Raffaello Sanzio da Urbino tarafından yapılan Haçın Görünüşü adlı resimde ise Konstantin başında ışın şeklinde bir taçla olduğu sırada gökyüzünde haç görünür219 (fig. 36). I. Konstantin, kendisinden önceki imparatorlar gibi olasılıkla güneş tanrısı Sol Invictus'u simgeleyen bir taç takar ${ }^{220}$. Haç yeni dinin ve İsa'nın sembolü olmakla birlikte göksel bir müjde olarak betimlenmiştir.

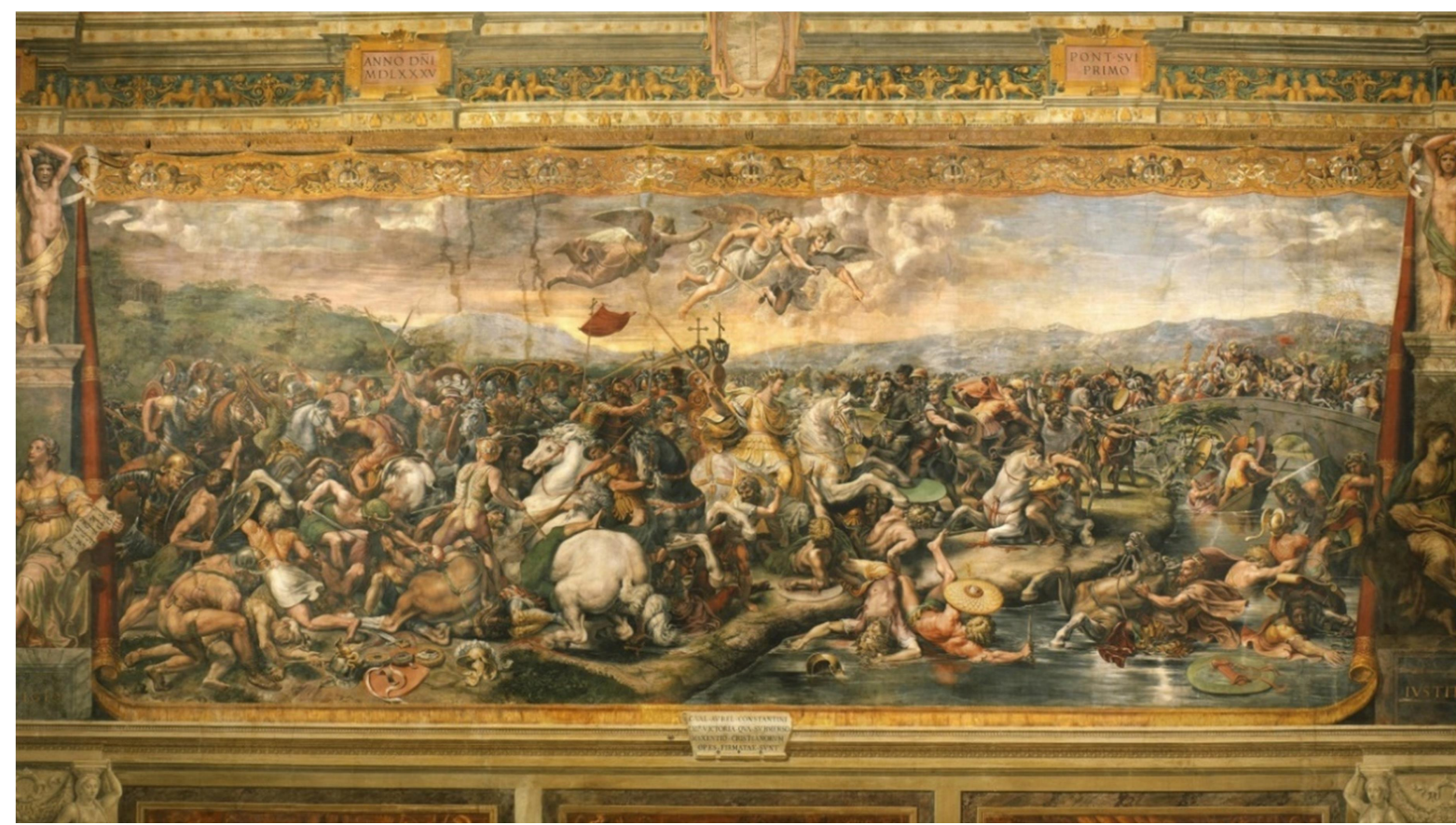

Figür 35: Guilio Romano “Milvian Köprüsü Savaşı” (1517-1524)

Güneş kültünün Suriye'den Roma'ya yayıldığı görüşü hatırlanırsa, Hristiyanlıkla birlikte burada sembolik anlamının nasıl dönüştüğü merak edilebilir. I. Peña, Suriye'deki Erken Hristiyanlık Dönemi yapılarının cephesinde lentolar üzerindeki dairesel motifi "güneş diski" olarak adlandırır. Bu motif madalyon içinde rüzgâr gülü, haç, yıldız gibi sembolik motiflerle birlikte yapılmıştır ${ }^{221}$. Araştırmacı tarafından güneş diskinin ikonografisi tamamen Hristiyanlıkla ilişkili yorumlanır. Buna göre "güneş diski, ışığın ve yaşamın kaynă̆ı olan tanrısalliğın ve ihtişamın görünür temsilidir. 36 ışınlı güneş diski yaygındır. Bu motif pagan kökenlidir, ancak 5. yüzyılda Deir Seta'da Hıristiyanlaştırılmıştır: güneş diskinin merkezinde bir haç vardır. Sembolizmi açıktır. Haç dünyayı aydınlatan ışıktır". Peña, bu dönüşümü en iyi ifade eden farklı bir örneği ise şöyle sunar: "Roma için on iki aya bölünmüş yılı temsil eden on iki ışınlı güneş

216 Askeri ekipmanlarda inanç sembolleri ayrı bir çalışmayı gerektirir. Geç Roma Dönemi askeri ekipmanları için bk. Coulston 2013, 463-492.

217 Halsberghe 1972.

218 “The Battle of Milvian Bridge," 2020.

219 "Vision of the Cross," 2020.

220 Hijmans 2006, 440-443; Hijmans 2009, 80-84, 509-548.

221 Peña 1997, 174. 
diski, Verona'lı Zeno'ya (375) göre 'on iki ışınlı bir taçla çevrelenmiş gerçek güneş olan İsa'nın sembolüdür"222. Araştırmac1, güneş diskinin sembolizmini Suriye'nin Malakbel'i ve Roma'nin Yenilmez Güneş/Sol Invictus inancından bağımsız değerlendirmiş ve motifin yalnızca pagan kökenli olduğunu belirtmekle yetinmiştir; ancak bunun Konstantin'in vizyonunda gökyüzünde beliren ışıktan yapılmış haçı hatırlattı̆̆ 1 açıktır. Bununla birlikte güneş kültünün Hristiyanlık için tehlike olduğu düşünüldüğünden olsa gerek, daha önce İskenderiyeli Klement, İsa'nın arabasını (Helios gibi) gökyüzüne sürdügünü dile getirirken, İsa'yı nasıl güneş tanrısı ile özdeştirdiyse, Ioannes Hrisostomos güneşle kıyasladığı haç için "haç güneşten daha parlak parlyyor" demiştir223. Bu sözler Erken Hristiyan din adamlarının güneş tanrisinı (pagan kültü) yenme mücadelesine şahitlik ettirir. Aynı zamanda dönemin teolojik düşünce biçimi tıpkı Panagia Sikelia Manastır

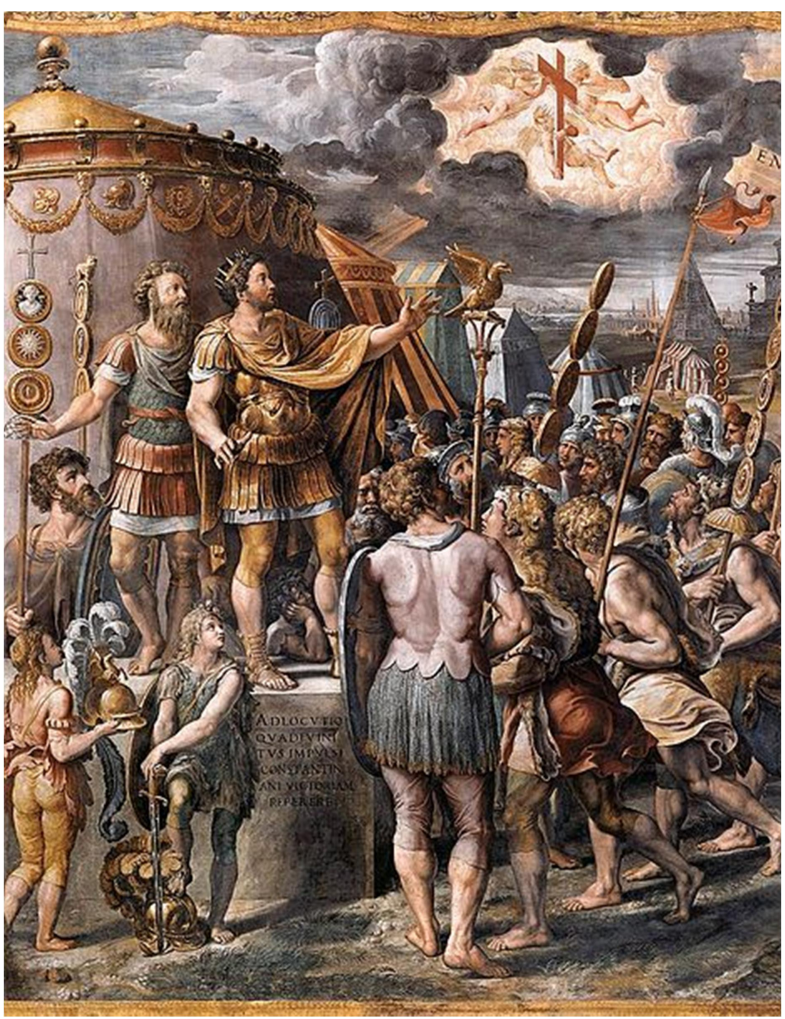

Figür 36: Raffaello Sanzio da Urbino "Haçın Görünüşü" $(1520-1524)$

Kilisesi güney cephesinde, etrafından ışınlar çıkan madalyon içindeki haç motifinde olduğu gibi, Ioannes Hrisostomos'un ilahi sözlerinin somutlaştırılmış hali olmalıdır²24.

\section{Sonuç}

Aziz Nikolaos Kilisesi kuzey ek yapısının tuğla ile hareketlendirilmiş cephesi, 11. yüzyıl Komnenoslar Dönemi mimari karakterini yansıtır. Kilisenin kuzey ve kuzeydoğu ek yapısının cephelerindeki tuğladan rozetler, manastır kompleksi içinde kutsal işleve sahip olduğu düşünülen mekanları vurgulamaktadır. Kuzeydoğu ek yapının cephesindeki rozet, üzerinin sıvalı ve boyalı olması açısından tek örnektir. Tuğla rozetler, Orta ve Geç Bizans Dönemi yapılarının cephelerinde yaygın olmakla birlikte kökeninin Geç Antik Dönem'e kadar uzandığı sanılır. Tuğla rozetler sembolik anlamları ve biçimsel özellikleri nedeniyle "güneş motifini" simgeler. Güneş motiflerinin haç, zikzak/testere dişi/chevron gibi motiflerle birlikte ortak bir repertuarın parçası olduğu anlaşılır. Hristiyanlıkta tuğladan yapılmış 1şınsal rozetlerin genellikle ilahi enerji ve ışıkla kurulan sembolik anlamı yaygındır. Işığın üç boyutluluk algısı ise K5 mekanındaki güneş motifinin altındaki frizde olduğu gibi testere dişi motifi ile sağlanır. Güneş motifleri kiliselerin yanı sıra saray, episkopeion, kale, kule, çeşme gibi farklı yapılarda uygulanmıştır. Ayrıca bu motifin başkent Konstantinopolis (İstanbul) dışında Anadolu, Yunanistan, İtalya, Bulgaristan, Makedonya ve Ege Adaları'ndaki örnekleri, Bizanslı yapı ustalarının ortak bir sembolik dil kullanıldığını gösterir.

3. yüzyıl Roma'nın yaygın inanışı olan "Yenilmez ya da Fethedilmez Güneş/Sol Invictus'a" tapınmanın en yüksek olduğu dönemdir. 4. yüzyılda ise dini siyaseti etkileyen iki

222 Peña 1997, 172, 174-175.

223 Peña 1997, 174.

224 Motif için bk. Ötüken 1978, 228, fig. 27; Ioannes Hrisostmos'tan aktarım için bk. Peña 1997, 174. 
önemli olay, Hoşgörü ve Milano Fermanlarının yayınlanmasıdır. Bu tarihten sonra Hristiyanlık aynı zamanda pagan bir inanış olan güneş kültüne karşı güçlü bir mücadele verir. Güneş inancı aynı yüzyıllarda sadece Hristiyanlık için değil, Yahudilik için de büyük bir tehlike olarak algılanmıştır. Kiliselerin cephesinde tuğladan haç motifleri ile birlikte veya merkezinde haç motifi bulunan rozetlerin ikonografisi konusunda farklı görüşler bulunur. Bu motif olasılıkla 4. yüzyıldan itibaren Erken Hristiyan sanatında, özellikle I. Konstantin'in vizyonu ile ilişkili ortak bir hafızayı canlandırır. Güneş motifi, 4. yüzyıldaki anlamını sonraki yüzyıllarda kaybetmiş olsa da ilahi ışı̆̆ı görsel bir şekilde anlatmanın yolu olarak kullanılmış olmalıdır. Bu 1şık, Geç Antik Dönem'de "Yenilmez Güneş/Sol Invictus'u" simgelerken, Hristiyanlığın serbest kalmasının ardından Konstantin'in vizyonundaki güneş ışı̆̆ından yapılmış haçı, ilahi ışığı yani tanrının ışıkla tezahürünü ya da İsa'yı simgeler. Geç Antik ve Erken Hristiyan sanatında karşılaştığımız pagan sembollerin yeni dine uyarlanması, güneş motiflerinde de anlamsal bir değişimle kendisini gösterir. Güneş motifi özellikle Anadolu'da Geç Bizans ve Erken Osmanlı Dönemi'nde Bizanslı ustalarca bilinçli olarak ya da zaman içinde başlangıçta bilinen sembolik anlamını kaybederek, yalnızca bir bezeme öğesi olarak devam etmiş olmalıdır. 


\begin{tabular}{|c|c|c|c|c|c|}
\hline & Yapı Adı & Tarihi & Bulunduğu yer & Güneş Motifi & $\begin{array}{l}\text { Haç } \\
\text { Motifi }\end{array}$ \\
\hline \multicolumn{6}{|c|}{ Erken Hristiyanlık ve Bizans Dönemi Örnekleri } \\
\hline 1 & Selanik Galerius Sarayı Oktagon yapı & 4. yüzyıl & Kuzey niş duvarı & + & $+(?)$ \\
\hline 2 & İtalya Terracina surları & 5. yüzyıl & & + & \\
\hline 3 & Köln surları & & & ++ & \\
\hline 4 & İstanbul Studios Manastırı & 5. yüzyıl ortaları & $\begin{array}{l}\text { Atrium kuzey } \\
\text { cephe }\end{array}$ & ++ & + \\
\hline 5 & Olympos peristyl çeşme & 6. yüzyıl & & + & + \\
\hline 6 & Olympos Episkopeion & 6. yüzyıl & $\begin{array}{l}\text { Triclinum kuzey } \\
\text { duvarı }\end{array}$ & ++ & \\
\hline 7 & Olympos Episkopeion & 6. yüzyıl & $\begin{array}{l}\text { Triclinium batı } \\
\text { duvarı }\end{array}$ & & + \\
\hline 8 & Zeytinbağ1/Tirilye (Fatih Camii) Kilisesi & $\begin{array}{l}\text { 8.-9. yüzyıllar/19. } \\
\text { yüzyıl }\end{array}$ & $\begin{array}{l}\text { Kubbe kasnağı, } \\
\text { batı cephe }\end{array}$ & + & + \\
\hline 9 & Ankara Kalesi & 9. yüzyıl ortası & İç sur & + & \\
\hline 10 & Bafa Gölü Kirselik Manastır Kilisesi & $\begin{array}{l}\text { 9.-11. yüzyıllar, } 13 \text {. } \\
\text { yüzyıl }\end{array}$ & Güney cephe & + & \\
\hline 11 & Kastoria Hagios Stephanos Kilisesi & 10.-11. yüzyıllar & Doğu cephe & ++ & Chi-Rho \\
\hline 12 & Kastoria H. Anargyriou Kilisesi & 10.-11. yüzyıllar & Doğu cephe & +++ & Chi-Rho \\
\hline 13 & Kastoria H. Anargyriou Kilisesi & 10.-11. yüzyıllar & Batı cephe & +++ & Chi-Rho \\
\hline 14 & Sakız Adası Nea Moni Manastır Kilisesi & 11. yüzyıl & $\begin{array}{l}\text { Kuzey ve güney } \\
\text { cephe }\end{array}$ & +++ (çarkıfelek) & + \\
\hline 15 & Bolu Çeltikdere Seben Kilisesi & 11. yüzyıl & Kuzey cephe & + & \\
\hline 16 & Isparta İslamköy Kilisesi & & & + & \\
\hline 17 & $\begin{array}{l}\text { İstanbul Pantepoptes Manastır Kilisesi (Eski } \\
\text { İmaret Camii) }\end{array}$ & $1081-1087$ & Güney cephe & Haç rozet & + \\
\hline 18 & $\begin{array}{l}\text { Myra Aziz Nikolaos Kilisesi kuzey ek yapı K5 } \\
\text { mekânı }\end{array}$ & 11.-12. yüzyıllar & Kuzey cephe & + & $+(?)$ \\
\hline 19 & $\begin{array}{l}\text { Myra Aziz Nikolaos Kilisesi kuzeydoğu ek yapı } \\
\text { C2 mekânı }\end{array}$ & 11.-12. yüzyıllar & Kuzey cephe & + & \\
\hline 20 & $\begin{array}{l}\text { İstanbul Philanthropos İsa Manastırı/Hristos } \\
\text { Soteros Kilisesi }\end{array}$ & 12. yüzy1l & $\begin{array}{l}\text { Alt yapı doğu } \\
\text { cephesi }\end{array}$ & + & $\begin{array}{c}\text { gamalı } \\
\text { haç }+\end{array}$ \\
\hline 21 & Gebze Eskihisar Kalesi kuzeybatı kulevari yapı & 11.-13. yüzyıl & Batı cephe & + & $\begin{array}{c}\text { gamalı } \\
\text { haç }\end{array}$ \\
\hline 22 & Bafa Gölü İkiz Ada (4 Nolu) Kilisesi & 11.-12. yüzyıl & Kuzey cephe & + & $?$ \\
\hline 23 & Bafa Gölü Kahve Asar (8 Nolu) Büyük Kilise & 11.-12./13. yüzy1l & Kuzey haç kolu & +++ & $?$ \\
\hline 24 & Sakız Adası Panagia Sikelia Kilisesi & 12.-13. yüzyıllar & Güney cephe & + & + \\
\hline 25 & Girit Kato Episkopi Siteias & 13. yüzyıl & Doğu cephe & ++ & + \\
\hline 26 & Konya, Sille Aya Elena Kilisesi & $\begin{array}{l}\text { Orta ve Geç Bizans/19. } \\
\text { yüzyıl }\end{array}$ & Kubbe kasnağı & 12 & \\
\hline 27 & $\begin{array}{l}\text { İstanbul Konstantin Lips Manastırı Güney } \\
\text { Kilisesi (Fenari İsa Camii) }\end{array}$ & $907 / 1281-1304$ & Doğu cephesi & +++ (çarkıfelek) & $\begin{array}{c}\text { gamalı } \\
\text { haç }\end{array}$ \\
\hline 28 & Kypseli (Tourkopalouko) St. Demetrios Kilisesi & 13. yüzyıl ortası & Doğu cephe & ++ & \\
\hline 29 & $\begin{array}{l}\text { İstanbul Pammakaristos Manastırı, Güney } \\
\text { Kilisesi (Fethiye Cami) }\end{array}$ & $1310-1315$ & Güney cephe & ++ & + \\
\hline 30 & $\begin{array}{l}\text { Selanik Peribleptos Meryem Manastırı, Aziz } \\
\text { Panteleimon Kilisesi }\end{array}$ & $\begin{array}{l}\text { geç 13.-erken } 14 . \\
\text { yüzyılın }\end{array}$ & Doğu cephe & + & + \\
\hline 31 & $\begin{array}{l}\text { Selanik Hagios Apostoloi Kutsal Havariler } \\
\text { Kilisesi (Soğuksu Camii) }\end{array}$ & $\begin{array}{l}1310-1314, \text { yaklaşık } \\
1329\end{array}$ & Doğu cephe & ++++ & \\
\hline 32 & $\begin{array}{l}\text { Bulgaristan Misivri-Nesebar Sv. Ivan } \\
\text { Aleiturgetos Kilisesi }\end{array}$ & 13.-14. yüzyıllar & Güney cephe & ++ & $\begin{array}{c}\text { Kakma } \\
\text { haç } \\
\text { oyuğu }\end{array}$ \\
\hline 33 & $\begin{array}{l}\text { Yunanistan Mistra Panagia Pantanassa } \\
\text { Bazilikası bitişik kule }\end{array}$ & 1428 & & $++?$ & \\
\hline \multirow[t]{2}{*}{34} & Ohri Aziz Klement ve Panteleimon Kilisesi & $\begin{array}{l}\text { Orta Bizans / yeniden } \\
\text { inşa 21. yüzyıl }\end{array}$ & Kubbe kasnağ1 & ++ & \\
\hline & \multicolumn{5}{|l|}{ Erken Osmanlı Dönemi Örnekleri } \\
\hline 1 & Bursa Orhan Camii & 14. yüzyıl & Giriş cephesi & + & \\
\hline 2 & Bursa Muradiye Medresesi & 14. yüzyıl & Yan cephe & + & \\
\hline 3 & Bursa Timurtaş Camii & & Giriş cephesi & + & \\
\hline 4 & Bursa Yıldırım Darüşşifası & $1399-1400$ & Giriş cephesi & + & \\
\hline 5 & Bursa Gülçiçek Hatun Türbesi & & Yan cephe & + & \\
\hline 6 & Yenişehir Seyyid Mehmet Dede Zaviyesi & 14. yüzyıl & Yan cephe & + & \\
\hline 7 & İznik Nilüfer Hatun İmareti & 14. yüzyıl & Yan cephe & + & \\
\hline 8 & Mustafa Kemal Paşa Lala Şahin Paşa Türbesi & 14. yüzyıl & Giriş cephesi & + & \\
\hline 9 & Bursa Çakaloğlu Hanı & 19. yüzyıl & Güney cephe & + & \\
\hline
\end{tabular}

Tablo 1. Tuğla Rozet/Güneş Motifi ve Haç Bezemeli Yapılar Listesi 


\section{Figürlerin Listesi}

Figür 1: Aziz Nikolaos Kilisesi Kuzey Ek Yapı Cephesi

Figür 2: Aziz Nikolaos Kilisesi Kuzey Ek Yapısı K4-K5 mekânı cephesi

Figür 3: Aziz Nikolaos Kilisesi kuzey Ek Yapı 2012-2013 restorasyon çalışmaları sonrası

Figür 4: Aziz Nikolaos Kilisesi Kuzey Ek Yapı K4 mekânı

Figür 5: Aziz Nikolaos Kilisesi Kuzey Ek Yap1 K5 mekânı kemerleri

Figür 6: Kuzey Ek Yapı K4 mekânı arkad kemerleri tuğla bezeme

Figür 7: Kuzey Ek Yapı K4 mekânı arkad kemerleri

Figür 8: Kuzey Ek Yapı K5 mekânı

Figür 9: Kuzey Ek Yapı K5 mekânı tuğla rozet/güneş motifi

Figür 10: Aziz Nikolaos Kilisesi Kuzey Ek Yapı K5 mekânı tuğla rozet/güneş motifi

Figür 11: Aziz Nikolaos Kilisesi Kuzeydoğu Ek Yapı C2 mekânı rozet/güneş motifi

Figür 12: Aziz Nikolaos Kilisesi Kuzeydoğu Ek Yapı C2 mekânı rozet/güneş motifi

Figür 13: Aziz Nikolaos Kilisesi Kuzeydoğu Ek Yapı C2 mekânı rozet/güneş motifi detay

Figür 14: Aziz Nikolaos Kilisesi Kuzey Ek Yapı K5 mekânı rozet/güneş motifi detay

Figür 15: Aziz Nikolaos Kilisesi Kuzeydoğu Ek Yapı C2 mekânı rozet / güneş motifi detay

Figür 16a-b: K5 ve C2 Yapısı rozet/güneş motiflerinin çizimi (Dijital çizim İ. Gültekin).

Figür 17: Studios Manastır Kilisesi atrium kuzey duvarındaki rozet ve haç motifi (Öztaşkın 2015)

Figür 18: Pantepoptes Manastır Kilisesi (Eski İmaret Camii) rozet motifi detayı (https://mapio.net/pic/p-70427494/)

Figür 19: Philantrophos İsa Manastırı Kilisesi alt yapısı doğu cephe (https://www.thebyzantinelegacy.com/christ-

philanthropos)

Figür 20: Philanthropos İsa Manastırı Kilisesi alt yapı rozet motifi detayı

(https://www.thebyzantinelegacy.com/christ-philanthropos)

Figür 21: Konstantin Lips Manastırı (Fenari İsa Camii) Güney Kilisesi doğu cephe

(https://www.thebyzantinelegacy.com/lips)

Figür 22: Konstantin Lips Manastırı (Fenari İsa Camii) Güney Kilisesi rozet motifi detay1

(https://youtube.com/watch?v=XxuK9ANp5is)

Figür 23: Sakız Adası Nea Moni Manastır Kilisesi (https://flickr.com/photos/gaeamade/16767368809)

Figür 24: Pammakaristos Manastırı Güney Kilisesi (https://fikriyat.com/kultur-sanat/2018/04/18/bir-kulturel-mirasalani-fethiye-camii)

Figür 25: Pammakaristos Manastırı Güney Kilisesi rozet motifi detayı (http://www.teomancimit.com/2787270-fethiyecami-pammakaristos)

Figür 26: Konya, Sille Aya Elena Kilisesi kubbe kasnağ1 (İ. M. Mimiroğlu)

Figür 27: Batı Makedonya Kastoria Hagios Stephanos Kilisesi doğu cephesi (https://www.petersommer.com/wpcontent/uploads/blog/2014/03/Kastoria-Agios-Stefanos.jpg)

Figür 28: Galerius Sarayı oktagon yapısı kuzey niş duvarı güneş motifi ve palmiye dalları

(http://galeriuspalace.culture.gr/en/monuments/oktagono/north-niche/)

Figür 29: Selanik Hagios Apostoloi Kutsal Havariler Kilisesi (Osmanlı Dönemi Soğuksu Camii) (Texier ve Pullan 1864)

Figür 30: Figür 30: Konstantin'in Göğe Yükselişi (Altın sikke, MS 337, British Museum, Env. no. 1986, 0610.1)

(https://britishmuseum.org/collection/object/C_1986-0610-1)

Figür 31: Roma, Eski Aziz Petrus Bazilikası Mousoleum M mozaik

(https://tr.wikipedia.org/wiki/Sol_Invictus\#/media/Dosya:ChristAsSol.jpg)

Figür 32: Girit Adası Kato Episkopi Siteias Kilisesi doğu cephe rozet ve haç motifi (Poulou ve Tantsis 2018)

Figür 33: Sakız Adası Nea Moni Manastır Kilisesi'nin cephesindeki haç ve güneş motifi

(https://www.tripadvisor.ru/LocationPhotoDirectLink-g189476-d196359-i307485215-Nea_Moni_Monastery-

Chios_Northeast_Aegean_Islands.html)

Figür 34: Figür 34: New York Metropolitan Müzesi'nde bulunan arabasını süren Sol tasvirli gemme (Env. no.

816.297) (https://metmuseum.org/art/collection/search/130005611)

Figür 35: Guilio Romano “Milvian Köprüsü Savaş1” (1517-1524)

(https://commons.wikimedia.org/wiki/File:Batalla_en_Puente_Milvio_entre_Constantino_y_Majencio.jpg)

Figür 36: Raffaello Sanzio da Urbino "Haçın Görünüşü" (1520-1524)

(https://commons.wikimedia.org/wiki/File:Sala_di_costantino,_visione_della_croce_03.jpg) 


\section{Bibliyografya}

\section{Antik Kaynaklar}

Eus. vita Const.: Eusebius, Vita Constantini; Kullanılan Metin ve Çeviriler: Eusebius of Caesarea, Life of Constantine. A. Cameron ve S. G. Hall. Oxford 1999.

Lact. mort. pers.: Lactantius, De Mortibus Persecutorum. Kullanılan Metin ve Çeviriler Lactantius, On the Deaths of the Persecutors. J. L. Creed. Oxford 1984.

\section{Modern Kaynaklar}

Akyürek, E. (2015). A Recently Discovered Thirteenth Century Church at Myra. S. Fazlullin ve M. M. Antika (Eds.), Proceedings of the 17th Symposium on Mediterranean Archaeology (SOMA): Moscow, 25-27 April 2013 (ss. 14-23). Oxford: Archaeopress Access Archaeology

Athanassiou, F., Malama, V., Miza, M. ve Sarandidou, M. (2006). The Construction Phases of The Octagon of the Galerius Palace Complex in Thessaloniki. Archaiologiko Ergo Ste-Makedonia Kai Thrake-, 18, 239-255.

Ayverdi, E. H. (1966). İstanbul Mimarî Çağının Menşei Osmanlı Mimarisinin İlk Devri Ertuğrul, Osman, Orhan Gaziler, Hüdâvendigâr ve Yildırım Bayezid 630-805 (1230-1402). İstanbul: İstanbul Fetih Cemiyeti Yayınları.

Bahar, B. (2013). İzmit Körfezi Bizans Dönemi Savunma Yapılan Bağlamında Gebze, Eskihisar Kalesi. [Yayımlanmamış Yüksek Lisans Tezi]. Hacettepe Üniversitesi.

Bardill, J. (2011). Constantine, Divine Emperor of the Christian Golden Age. New York: Cambridge University Press.

Bassett, S. (2004). The Urban Image of Late Antique Constantinople. Cambridge: Cambridge University Press.

Buchwald, H. (1979). Lascarid Architecture. JÖB, 28, 261-296.

Buchwald, H. (1984). Western Asia Minor as a Generator of Architectural Forms in the Byzantine Period, Provincial Back-wash or Dynamic Center of Production. JÖB, 34, 198-234.

Buchwald, H. (1999). Form, Style and Meaning in Byzantine Church Architecture. Variorum Collected Studies. Farnham: Ashgate Publishing.

Ćirić, J. S. (2016). As the Byzantines Saw It: Sensoria, Sources, Apse and Brickwork at the end of 13th-Century. M. Rakocija (Ed.), Niš and Byzantium, Fourteenth International Symposium, Niš, 3-5 June 2015 (ss. 305-314). Niš.

Coulston, J. C. N. (2013). Late Roman Military Equipment Culture. A. Sarantis ve N. Christie (Eds.), War and Warfare in Late Antiquity (ss. 463-492). Leiden-Boston: Koninklijke Brill NV. https://doi.org/10.1163/9789004252585_015

Ćurčić, S. (2012). Divine Light: Constructing the Immaterial in Byzantine Art and Architecture. B. D. Wescoat ve R. G. Ousterhout (Eds.), Architecture of the Sacred, Space, Ritual and Experience from Classical Greece to Byzantium (ss. 307-337). Newyork: Cambridge 
University Press. https://doi.org/10.1017/CBO9781139017640

Çalık-Ross, A. (2017). Hoşgörü Başkenti Nikomedia ve Galerius'un Hoşgörü Fermanının Çeviri Denemesi. Kocaeli Üniversitesi Fen-Edebiyat Fakültesi Sosyal Bilimler Araştırma DergisiKOUSBAD, 6, 135-145.

Danık, E. (1997). Konya, Sille' deki Aya Elena Kilisesi. Türk Etnoğrafya Dergisi, 20, 177-193.

Demiriz, Y. (1979). Osmanlı Mimarisinde Süsleme I, Erken Devir (1300-1453). Kültür Bakanlı̆̆1 Yayınları 263, Türk Sanat Eserleri Serisi 2. İstanbul: Kültür Bakanlı̆̆1 Yayınları.

Dey, H. (2010). Art, Ceremony, and City Walls: The Aesthetics of Imperial Resurgence in the Late Roman West. Journal of Late Antiquity, 3(1), 3-37.

Dirven, L. (1999). The Palmyrenes of Dura-Europos: A Study of Religious Interction in Roman Syria. Leiden: Brill.

Doğan, S., Findık, E. F. ve Bulgurlu, V. (2013). Myra (Demre) Aziz Nikolaos Kilisesi Koruma ve Onarım Çalışmaları 2012. Kazı Sonuçları Toplantısı, 35(3), 292-301.

Doğan, S., Fındık, E. F. ve Bulgurlu, V. (2019). Myra (Demre) Aziz Nikolaos Kilisesi Koruma ve Onarım Çalışmaları - 2017. Kazı Sonuçlan Toplantısı, 40(3), 365-380.

Doğancı, K. (2017). Constantinus'un Hristiyanlığı Meselesi ve Ölümü Hakkındaki Tartışmalar. Uludă̆ Üniversitesi Fen-Edebiyat Fakültesi Sosyal Bilimler Dergisi, 18(33), 493-517.

Drake, H. (2016). The emperor as a 'Man of God': The impact of Constantine the great's: Conversion on roman ideas of kingship, Historia, 35(1), 1-17.

Epstein, A. W. (1980). Middle Byzantine Churches of Kastoria: Dates and Implications. ArtB, 62(2), 190-207.

Eyice, S. (1963). Son Devir Bizans Mimarisi İstanbul'da Palaiologoslar Devri Anıtları. İstanbul: İstanbul Üniversitesi Edebiyat Fakültesi Yayınları.

Eyice, S. (1966). Konya ile Sille Arasındaki Akmanastır, Menakib al-ârifî̀n'deki Deyr-i Eflatun. Şarkiyat Mecmuası, 6, 135-160.

Eyice, S. (1969). “Trakya'da Bizans Devrine Ait Eserler,” Belleten, 131, 325-358.

Findık, E. F. (2019). Kandiller. N. Tekdemir ve D. Hadzibegoviç (Eds.), Bir Koleksiyonerin Tutkusu, Rahmi M. Koç Koleksiyonundan Seçmeler (ss. 171-201). İstanbul: Yapı Kredi Yayınları.

Freely, J. ve Çakmak, A. S. (2005). İstanbul'un Bizans Anıtları. (Çev. G. Tanman). İstanbul: Yapı Kredi Yayınları.

Friedheim, E. (2009). Sol Invictus in the Severus Synagogue at Hammath Tiberias, the Rabbis, and Jewish Society: A Different Approach. Review of Rabbinic Judaism. 12(1), 89-128.

Grabar, A. (1968). Early Christian Art from the Rise of Christianity to the Death of Theodosius. New York: Odyssey Press. 
Guarducci, M. (1957/1959). Sol invictus Augustus. RendPontAcc, 3(30/31), 161-169.

Halsberghe, G. (1972). The cult of Sol Invictus. Leiden: Brill.

Hargrove, E. N. (2015). The Roman Sun: Symbolic Variation in Ancient Solar Warship [Unpublished master's thesis]. Universiteit Van Amsterdam.

Hijmans, S. E. (1996). The Sun which did not rise in the East; the Cult of Sol Invictus in the Light of Non-Literary Evidence. BABesch, 71, 115-150.

Hijmans, S. E. (2003). Sol Invictus, The Winter Solstice, and the Origins of Christmas. Mouseion: Journal of the Classical Association of Canada, 3(3), 377-398.

Hijmans, S. E. (2006). Metaphor, Symbol and Reality: the Polysemy of the Imperial Radiate Crown. C. C. Mattusch (Ed.), Common ground. Archaeology, art, science, and humanities. Proceedings of the XVIth International Congress of Classical Archaeology Boston, August 23-26, 2003 (ss. 440-443). Oxford: Oxford University Press.

Hijmans, S. E. (2009). Sol: the sun in the art and religions of Rome [Unpublished doctoral dissertation]. University of Groningen.

Hijmans, S. E. (2011). Usener's Christmas: A Contribution to the Modern Construct of Late Antique Solar Syncretism. M. Espagne ve P. Rabault-Feuerhahn (Eds.), Hermann Usener und die Metamorphosen der Philologie (ss. 139-152). Wiesbaden: Harrassowitz.

Hobbs, L. M. (2014). The Religion of Constantine I: An Analysis of the Modern Scholarly Hypotheses and Interpretations of the Contemporary Evidence [Unpublished master's thesis]. University of Ottawa. https://ruor.uottawa.ca/handle/10393/31413

Hoddinott, R. F. (1963). Early Byzantine Churches of Macedonia and Southern Serbia: A Study of the Origins and the Initial Development of East Christian Art. London: Macmillan.

Jevtić, I. (2019). Painted Church Facades in Byzantine and "Post-Byzantine" Art and Their Aesthetics. Actual Problems of Theory and History of Art: Collection of articles, 9, 318-325.

Kaçar, T. (2013). Roma İmparatorluğu, Hıristiyanlar ve Milano Fermanı'nın 1700. Yılı. Toplumsal Tarih Dergisi, 230, 46-50.

Kalfazade, S. (1987). Erken Osmanlı Mimarisinde Tuğla Rozetler Hakkında. Sanat Tarihi Araştırmaları Dergisi, 1, 12-17.

Kaymaz, Y. (2014). Büyük Constantinus'un Hıristiyanlığı Meselesi. Sakarya Üniversitesi İlahiyat Fakültesi Dergisi, 26(29), 213-235.

Kırıkçı, E. (2004). 12 ve 13. Yüzyılların Anadolu Türk Süsleme Sanatında Güneş, Ay ve Yıldız Simgelerinin Değerlendirilmesi [Yayınlanmamış Yüksek Lisans Tezi] İstanbul Üniversitesi.

Klose, C. (2015). A Farewell to Methods? Imperial 'adventus-scenes' and Interpretations of Roman Historical Reliefs. C. Klose, L. C. Bossert ve W. Leveritt (Eds.), Fresh Perspectives on Graeco-Roman Visual Culture. Proceedings of an International Conference at Humboldt-Universität, Berlin, 2nd-3rd September 2013 (ss. 99-116). DOI: 10.18452/17865 
Kolay, E. ve Erdoğan, O. (2019). Zikzak: Bir Ortaçağ Motifinin Anadolu Yansımaları. Mediterranean Journal of Humanities. 9(1), 241-256.

Kourkoutidou-Nikolaidou, E. ve Tourta, A. (1997). Wandering in Byzantine Thessaloniki. Athens: Kapon Editions.

Kuban, D. (2016). Osmanlı Mimarisi. İstanbul: YEM Yayınları.

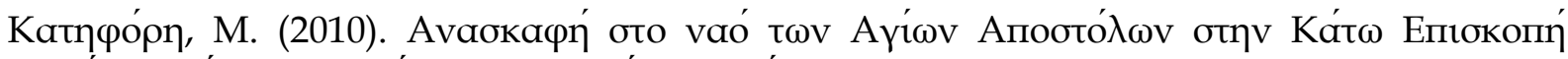

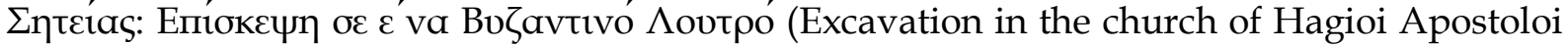
in Kato Episkopi Siteias: Visiting a Byzantine bath-house). M. Andrianakis ve I. Tzachili (Eds.), In Archaeological Works in Crete 1 (ss. 211-222). Publications of the School of Philosophy of the University of Crete: Rethymno.

Laughlin, T. Y. (2007). The Controversy of Constantine's Conversion to Christianity. Student Theses, Papers and Projects (History). 172. https:// digitalcommons.wou.edu/his/172

Lossky, V. (1997). The Mystical Theology of the Eastern Church. Cambridge: Lutterworth Press.

Macridy, T. (1964). The Monastery of Lips, the Burials of the Palaeologi. DOP, 18(23), 253277.

Makaronas, Ch. (1969). Hē kamara, to thriambiko toxo tou Galeriou stē Thessalonikē (No.107). Thessalonikē: Hetaireia Makedonikōn Spudōn.

Marlowe, E. (2006). Framing the Sun: The Arch of Constantine and the Roman Cityscape. ArtB, 88(2), 223-242.

Matern, P. (2002). Helios und Sol: Kulte und Ikonographie des griechischen und römischen Sonnengottes. İstanbul: Ege Yayınları.

Mathews, T. (1976). The Byzantine Churches of Istanbul: A Photographic Survey. Pennsylvania: Pennsylvania State University Press.

Mercangöz, Z. (1990). Bafa Gölü Kirselik'teki Manastır Kilisesi. Arkeoloji ve Sanat Tarihi Dergisi, 5, 117-138.

Mercangöz, Z. (1992). Kapıkırı Adası'ndaki Manastır Kilisesi Üzerine Düşünceler. Arkeoloji ve Sanat Tarihi Dergisi, 6, 73-90.

Mercangöz, Z. (1995). Batı Anadolu'daki Türk Yapılarının Duvar Tekniği ve Tuğla Süslemelerin Kaynağı Üzerine Düşünceler. 9. Milletlerarası Türk Sanatları Kongresi, Cilt 2 (ss. 485-495). Ankara: Türk Tarih Kurumu.

Miljkoviḱ-Pepek, P. (1981). Veljusa: manastir Sv. Bogorodica Milostiva vo seloto Veljusa kraj Strumica. Skopje: Fakultet za filozofsko-istoriski nauki na univerzitetot "Kiril i Metodij".

Mimiroğlu, İ. M. (2013). A Building Dedicated to Archangel Michael: The Hagia Eleni Church in Sille. İ. M. Mimiroğlu (Ed.) Sille Hagia Eleni Museum (ss. 174-219). Konya: Selçuklu Belediyesi Yayınevi.

Mimiroğlu, İ. M. (2018). Aya Elena Kilisesi. M. Birekul (Ed.) Konya Ansiklopedisi (ss. 353-354) 
Konya: Konya Büyükşehir Belediyesi Kültür Yayınları.

Moss, R. L. (2000). Romanesque Chevron Ornament. [Unpublished doctoral dissertation]. University of Dublin. http:// tara.tcd.ie/handle/2262/80260

Nixon, C. E. V. ve Rodgers, B. S. (1994). In Praise of Later Roman Emperors: The Panegyrici Latini. Berkeley: University of California Press.

Odahl, C. M. (2004). Constantine and the Christian Empire. Newyork: Routledge Publisher.

Ousterhaout, R. (1985). The Byzantine Church at Enez: Problems in Twelfth-Century Architecture. JÖB, 35, 261-280.

Ousterhaut, R. (1987). The Architecture of the Kariye Camii in Istanbul. Washington: Dumbarton Oaks Research Library and Collection.

Ousterhout, R. (1991). Constantinople, Bithynia, and Regional Developments in Later Palaeologan Architecture. Ćurčić, S. ve Mouriki, D. (Eds.), The Twilight of Byzantium (ss. 75110). Princeton: Princeton University Press.

Ousterhout, R. (2014). The life and afterlife of Constantine's Column. JRA, 27, 304-326.

Ötüken, S. Y. (1978). Istanbul Son Devir Bizans Mimarisinde Cephe Süslemeleri. Vakıflar Dergisi, 12, 213-233.

Ötüken, S. Y. (1990). Bizans Duvar Tekniğinde Tektonik ve Estetik Çözümler. Vakıflar Dergisi, 22, 395-403.

Ötüken, S. Y. (1997a). Likya Ortaçağ Araştırmaları ve Demre Aziz Nikolaos Kilisesi Kazısı. Adalya, 1, 73-85.

Ötüken, S. Y. (1997b). 1995 Yılı Demre Aziz Nikolaos Kilisesi Kazısı. Kazı Sonuçları Toplantısı, 18(2), 471-487.

Ötüken, S. Y. (2002). Demre-Myra Aziz Nikolaos Kilisesi Kazısında Yeni Sonuçlar. M. Denktaş, Ö. Yıldıray ve A. Sağıroğlu-Arslan (Eds.), VI. Ortaçă̆ Türk Dönemi Kazılar ve Araştırmaları Sempozyumu (ss. 585-599). Kayseri.

Ötüken, S. Y. (2005). 2002 Yilı Demre-Myra Aziz Nikolaos Kilisesi Kazısı ve Duvar Resimlerini Koruma-Onarım ve Belgeleme Çalışmaları. Adalya, 8, 261-285.

Ötüken, S. Y. (2007). Işık Yaşam PWC -ZHW. C. Işık, Z. Çizmeli-Öğün, ve B. Varkıvanç (Eds.), Calbis: Baki Öğ̈̈n'e Armağan (ss. 131-136). Ankara: Türk Tarih Kurumu.

Ötüken, S. Y., Alpaslan, S. ve Acara, M. (1999/2000). Demre-Myra Aziz Nikolaos Kilisesi Kuzey Ek Yapısının Yeni Bir Değerlendirilmesi. Adalya, 4, 221-242.

Ötüken, S. Y. ve Ousterhout, R. (1995). The Byzantine Church at Celtikdere. B. Borkopp, B. Schellewald ve L. Thiess (Eds.), Studien Zur Byzantinischen Kunstgeschichte Festschrift Für Horst Hallensleben Zum 65. Geburtstag (ss. 85-92). Amsterdam: Hakkert. 
Öztaşkın, G. K. (2015). Olympos Episkopeionu Tuğla Süslemeleri. T. Kahya, A. Özdizbay, N. Tüner-Önen ve M. Wilson (Eds.) Uluslararası Genç Bilimciler Buluşması II: Anadolu Akdenizi Sempozyumu (ss. 615-627). Antalya: AKMED/Koç Üniversitesi Suna \& İnan Kıraç Akdeniz Medeniyetleri Araştırma Merkezi.

Pekak, S. (2009). Trilye (Zeytinbă̆̆) Fatih Camisi, Bizans Kapalı Yunan Haçı Planı, İstanbul: Arkeoloji ve Sanat Yayınları.

Peña, I. (1997). The Christian art of Byzantine Syria. England: Garnet Publications.

Peschlow, U. (1975). Die Arkhitektur der Nikolaoskirche in Myra. J. Borchardt (Ed.), Myra: Eine lykische Metropole in antiker und byzantinischer Zeit, IstForsch, 30, 303-359.

Peschlow, U. (1990). Materialien zur Kirche des H. Nikolaos in Myra im Mittelalter. IstMitt, $40,207-258$.

Peschlow, U. (2000). Die byzantinische Kaiserinschrift aus Myra-Wiedergefunden. Lykia, 3, 75-78.

Poulou, N. ve Tantsis, A. (2018). From Town to Countryside: Middle-Byzantine Bath-Houses in Eastern Crete and Their Changing Functions. Land, 7(3), 1-15.

Radojčić, S. (1971). Milesěva. Beograd: Srpska Književna Zadruga.

Schwartz, E. (1977). The Whirling Disc: A Possible Connection between Medieval Balkan Frescoes and Byzantine Icons. Zograf, 8, 24-29.

Schweiger-Lerchenfeld, A. (Freiherr von) (1887). Griechenland in Wort und Bild. Eine Schilderung des hellenischen Königreiches. Leipzig: Heinrich Schmidt \& Carl Günther.

Serin, U. (2014). Bizans Ankarası ve Kaybolan Bir Kültür Mirası: "St. Clement" Kilisesi. METU Journal of the Faculty of Architecture, 31(2), 65-92.

Şen, E. ve Gürpınar, F. (2019). Farklı Kültürlerde Güneş Sembolü. Ulakbilge Sosyal Bilimler Dergisi, 43, 985-1008.

Texier, C. ve Pullan, R. P. (1864). Byzantine Architecture illustrated by a series of the earliest Christian edifices in the East. London: Day and Son.

Tomoioagă, F. T. (2015). The Vision of Divine Light in Saint Gregory Palamas's Theology. Acta Theologica, 35(2), 142-153.

Trkulja, J. (2011). Divine Revelation Performed: Symbolic and Spatial Aspects in the Decoration of Byzantine Churches. A. Lidov (Ed.), Spatial Icons: Performativity in Byzantium and Russia (ss. 213-246). Moscow: Indrick.

Trkulja, J. (2012). The rose window: a feature of Byzantine architecture?. M. J. Johnson, R. Ousterhout ve A. Papalexandrou (Eds.), Approaches to Byzantine Architecture and its Decoration Studies in Honor of Slobodan Ćurčić (ss. 143-161). Farnham: Ashgate Publishing.

Üçer-Karababa, İ. Ü. (2020). Roma Dönemi Tören Alaylarının Kent Dokusuna Etkileri: Roma ve İstanbul' daki Zafer Alayları. Olba, 14, 127-148. 
Verim, E. (2017). Çeltikdere'de Kapalı Yunan Haçı Planlı Bir Kilise. History Studies International Journal of History, 9(2), 235-256.

Vickers, M. (1973). Observations on the Octagon at Thessaloniki. JRS, 63, 111-120.

Watson, A. (2004). Aurelian and the Third Century. Oxford: Routledge Publisher.

Webb, M. (2001). The Churches and Catacombs of Early Christian Rome. Eastbourne: Sussex Academic Press.

Yoncaci-Arslan, P. (2016). Towards A New Honorific Column: The Column of Constantine in Early Byzantine Urban Landscape. METU Journal of the Faculty of Architecture, 33(1), 121-145.

\section{Online Kaynaklar}

Aziz Apostoli Kilisesi. (2020, Ekim 15).

http://www.explorechios.gr/tr/alternatif-turizm/dini-turizm/74-aziz-apostoli-kilisesi

İmrahor İlyas Bey Camii. (2020, Ekim 01).

https://libdigitalcollections.ku.edu.tr/digital/collection/BYGA/id/552/

Eski İmaret Mosque. (2020, Ekim 15).

https://www.thebyzantinelegacy.com/pantepoptes.

Monastery of Christ Philanthropos. (2020, Ekim 20).

https://www.thebyzantinelegacy.com/christ-philanthropos

Monastery of Lips. (2020, Eylül 07).

https://www. thebyzantinelegacy.com/lips.

Nea Moni - Chios. (2020, Eylül 15).

https://www.flickr.com/photos/gaeamade/16767368809/

Saint Panteleimon church. (2021, Ocak 02).

https://tr.123rf.com/photo_54301657_details-of-saint-panteleimon-church-plaosnik-in-ohridmacedonia.html.

Grande Flânerie. (2020, Eylül 27).

https://grandeflanerie.com/portfolio/byzantinethessaloniki/2/

Church of the Holy Apostles. (2020, Ekim 25).

https://www.thebyzantinelegacy.com/apostoloi-thessaloniki

Church of the Holy Apostles. (2020, Kasim 24).

https://www.thebyzantinelegacy.com/holy-apostles.

Sakız Adası Manastırları. (2021, Ocak 21).

https://www.sakizadasi.com/manastirlari/

Quora. (2020, Eylül 20). 
https://www.quora.com/Did-the-Byzantines-still-revere-Agustus-and-Caesar-once-the-empireconverted-to-Christianity

Terracotta Lamp. (2020, Eylül 23).

https://www.alamy.com/stock-image-terracotta-lamp-imperial-ca-ad-75125-roman-cypriot-terracottamold-162387257.html

Imperial Panegyrics. (2020, Aralık 25).

http://employees.oneonta.edu/farberas/arth/arth212/imperial_panegyrics.html

Constantine the Great Sol Bronzes. (2020, Eylül 19).

http://rg.ancients.info/constantine/Sol_other.html

The god Sol in quadriga. (2020, Eylül 19).

http://ancientrome.ru/art/artworken/img.htm?id=2118

Sol Invictus. (2020, Eylül 19).

https://www.roger-pearse.com/weblog/2015/11/25/is-there-a-distinctive-iconography-for-sol-invictus/

Nea Moni (2021, Şubat 06).

https://www.tripadvisor.ru/LocationPhotoDirectLink-g189476-d196359-i307485215-

Nea_Moni_Monastery-Chios_Northeast_Aegean_Islands.html

Gamalı Haçın Tarihi (2021, Şubat 05).

https://encyclopedia.ushmm.org/content/tr/article/history-of-the-swastika

Oktagon North Niche. (2020, Ekim 15).

http://galeriuspalace.culture.gr/en/monuments/oktagono/north-niche/

Probus, Antoninianus. (2021, Ocak 9).

https://www.beastcoins.com/RomanImperial/V-II/Probus/Siscia/Siscia.htm

Jasper intaglio. (2021, Ocak 16).

https://www.metmuseum.org/art/collection/search/130005611.

Emperor Iustinianus. (2021, Ocak 02).

https://en.wikipedia.org/wiki/Scholae_Palatinae\#/media/File:Sanvitale03.jpg.

The Battle of Milvian Bridge. (2020, Ekim 15).

https://commons.wikimedia.org/wiki/File:Battle_of_the_Milvian_Bridge_by_Giulio_Romano,_1520-

24.jpg.

Vision of the Cross. (2020, Ekim 15).

https://en.wikipedia.org/wiki/The_Vision_of_the_Cross\#/media/File:School_of_Raphael_-

_Vision_of_the_Cross.jpg. 